\title{
The Guideline of Diagnosis and Treatment of Attention-Deficit Hyperactivity Disorder: Developed by ADHD Translational Research Center
}

\author{
Sumin Lee', Jae-Won Choi ${ }^{1}$, Kyoung-Min Kim', Jun Won Kim², Sooyeon Kim', Taewoong Kang ${ }^{3}$, \\ Johanna Inhyang Kim${ }^{1}$, Young Sik Lee ${ }^{4}$, Bongseog Kim${ }^{5}$, Doug Hyun $\mathrm{Han}^{4}$, \\ Jae Hoon Cheong ${ }^{6}$, Soyoung Irene Lee ${ }^{7}$, Gi Jung Hyun ${ }^{4}$, and Bung-Nyun Kim ${ }^{1}$ \\ ${ }^{1}$ Division of Child and Adolescent Psychiatry, Department of Psychiatry, Seoul National University College of Medicine, Seoul, Korea \\ ${ }^{2}$ Department of Psychiatry, Catholic University of Daegu School of Medicine, Daegu, Korea \\ ${ }^{3}$ Inarae Psychiatric Clinic, Cheongju, Korea \\ ${ }^{4}$ Department of Psychiatry, Chung-Ang University Hospital, College of Medicine, Chung-Ang University, Seoul, Korea \\ ${ }^{5}$ Department of Psychiatry, Sanggye Paik Hospital, School of Medicine, Inje University, Seoul, Korea \\ ${ }^{6}$ Uimyung Research Institute for Neuroscience, Sahmyook University, Seoul, Korea \\ ${ }^{7}$ Department of Psychiatry, Soonchunhyang University College of Medicine, Bucheon Hospital, Bucheon, Korea
}

\section{주의력결핍 과잉행동장애 진단 및 치료: $A D H D$ 중개연구센터 가이드라인}

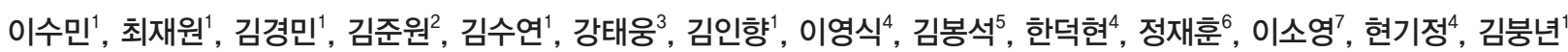

서울대학교 의과대학 정신건강의학교실 소아정신분과, ${ }^{1}$ 대구가톨릭대학교 의과대학 정신건강의학교실, ${ }^{2}$

아이나래 정신건강의학과의원, ${ }^{3}$ 중앙대학교 의과대학 중앙대학교병원 정신건강의학교실, ${ }^{4}$

인제대학교 의과대학 상계백병원 정신건강의학교실, ${ }^{5}$ 삼육대학교 의명신경과학연구소, ${ }^{6}$ 순천향대학교 의과대학 부천병원 정신건강의학교실

\begin{abstract}
Attention-deficit hyperactivity disorder (ADHD) is one of the most common childhood psychiatric conditions. In 2007, the Korean Academy of child and Adolescent Psychiatry developed Korean ADHD practice parameter. Advances in the scientific evidence of ADHD caused practice parameter to be modified and updated. The present guidelines developed by ADHD translational research center summarize current literature for the treatment of ADHD in children and adults. This parameter includes the clinical evaluation for ADHD, comorbid conditions associated with ADHD, clinical feature and course, research on the etiology of the disorder, and psychopharmacological and nonpharmacological treatments for ADHD.
\end{abstract}

Key Words: ADHD; Clinical practice guidelines; Diagnosis; Treatment.

Received: November 7, 2016 / Revision: December 27, 2016 / Accepted: December 28, 2016

Address for correspondence: Bung-Nyun Kim, Division of Child and Adolescent Psychiatry, Department of Psychiatry, Seoul National University College of Medicine, 101 Daehak-ro, Jongno-gu, Seoul 03080, Korea

Tel: +82-2-2072-3647, Fax: +82-2-747-5774, E-mail: kbn1@snu.ac.kr

\section{진단 및 평가}

\section{진단기준의 변화}

주의력결핍 과잉행동장애(attention-deficit hyperactivity disorder, $\mathrm{ADHD})$ 는 과잉행동과 부주의, 충동성의 세 가지 특성 을 가지는 장애이다. 2013년에 개정된 DSM-5에서는 이전 진 단기준에 비하여 발달학적 관점을 더 고려하였다. DSM-5에

This is an Open Access article distributed under the terms of the Creative Commons Attribution Non-Commercial License (http://creativecommons.org/licenses/by-nc/3.0) which permits unrestricted non-commercial use, distribution, and reproduction in any medium, provided the original work is properly cited.
서는 $\mathrm{ADHD}$ 의 발병연령을 7세 이전에서 12세 이전으로 변경 하였고, 연령이 높아지면서 과잉행동이 감소하는 것을 고려하 여 17세 이상, 성인에서는 부주의와 과잉행동 및 충동성 두 영역 모두에서 진단기준 5 개 이상으로 변경되었다(소아의 경우 이전과 같이 6개). 이전에 아형(subtype)이라 불리던 세부 유형 을 현재 상태(current presentation)로 변경하였으며 현재의 증 상 심각도를 경도, 중등도, 중증으로 평가하게 하였다. 그리고 배제진단에서 자폐스펙트럼장애가 제외되어 $\mathrm{ADHD}$ 와 동반 진 단이 가능하게 되었다. ${ }^{1)} \mathrm{DSM}-\mathrm{IV}-\mathrm{TR}$ 과 DSM-5의 차이점은 Table 1에 정리하였다. 
Table 1. The difference between DSM-IV and DSM-IV ${ }^{292)}$

\begin{tabular}{|c|c|c|}
\hline Criteria & DSM-IV & DSM-5 \\
\hline \multicolumn{3}{|l|}{ Symptoms } \\
\hline Inattention & Six of nine symptoms & $\begin{array}{l}\text { Six of nine symptoms in children; five of nine symptoms } \\
\text { in adoles-cents and adults ( } \geq 17 \mathrm{yr} \text { ) }\end{array}$ \\
\hline $\begin{array}{l}\text { Hyperactivity and } \\
\text { impulsivity }\end{array}$ & Six of nine symptoms & $\begin{array}{l}\text { Six of nine symptoms in children; five of nine symptoms } \\
\text { in adoles-cents and adults ( } \geq 17 \mathrm{yr})\end{array}$ \\
\hline Age at onset & $<7 \mathrm{yr}$ & $<12 \mathrm{yr}$ \\
\hline Settings & $\begin{array}{l}\text { Either inattention or hyperactivity-impulsivity } \\
\text { in } \geq 2 \text { settings }\end{array}$ & $\geq 2$ settings \\
\hline Impairment & $\begin{array}{l}\text { Clinically significant impairment in social, } \\
\text { academic, or occupational functioning }\end{array}$ & $\begin{array}{l}\text { Interference with functioning or devel-opment; specify } \\
\text { mild, moderate, or severe functional impairment or } \\
\text { symptoms }\end{array}$ \\
\hline Subtypes & $\begin{array}{l}\text { ADHD: combined type (inattentive and } \\
\text { hyperactive-impulsive), predominantly } \\
\text { inattentive type, or predominantly } \\
\text { hyperactive type }\end{array}$ & $\begin{array}{l}\text { ADHD: combined inattentive and hy-peractive-impulsive } \\
\text { presentation, predominantly inattentive presenta-tion, } \\
\text { or predominantly hyperactive-impulsive presentation }\end{array}$ \\
\hline
\end{tabular}

\section{선별(Screening)}

$\mathrm{ADHD}$ 의 선별은 심리적 고통이나 정신병적 문제로 병원을 찾은 사람뿐 아니라 심리 센터, 학교 상담실 등 비의료기관을 방문한 사람들에게도 이루어져야 한다. 선별하는 임상의 혹은 상담가는 미리 $\mathrm{ADHD}$ 증상 척도 혹은 특정 설문지를 비치하 는 것이 도움이 된다. 선별 시 $\mathrm{ADHD}$ 의 세 주요 증상인 부주 의, 과잉행동, 충동성 모두가 있어야 하는 것은 아니며 특히 여 성과 성인의 경우 과잉행동 증상이 없을 수도 있음을 인지하 고 있어야 한다. ${ }^{2}$ 임상의는 선별을 위하여 환자가 방문하였을 때부터 이후 진단 과정과 치료를 위하여 환자 및 보호자와 관 계형성에 노력해야 한다. ${ }^{3)}$ 아동과 보호자는 자신들의 증상에 대하여 너무 자세히 이야기하는 것을 힘들어 할 수 있으며 이 에 대하여 임상가가 너무 자세히 질문하는 것은 주의가 필요 하다. 또한 다음 방문을 예약 시 아동의 과거 생활에 대한 정보 를 제공할 수 있는 학생기록부 혹은 이전 병원의 진료기록을 요청해야 한다. 시행한 척도에서 절단점 이상의 점수가 나왔거 나 장애를 일으킬 정도의 증상이 확인이 되었다면 $\mathrm{ADHD}$ 의 전반적인 평가를 시행하기 위하여 전문의료기관으로 의뢰해 야 한다.

\section{평가(Evaluation)}

\section{$\mathrm{ADHD}$ 증상에 대한 면담(ADHD symptoms review)}

전반적인 평가 면담은 $\mathrm{DSM}-5$ 의 진단기준 각각에 대하여 자세히 물어보아야 한다. 부주의와 과잉행동/충동성의 각 9 개 의 기준 중에 17 세 미만은 6 개, 17 세 이상은 5 개 이상 해당 증상 이 있어야 하며 두 도메인 중에 해당하는 증상에 따라 부주의 우세형, 과잉행동/충동우세형, 복합형으로 나누어질 수 있다.
$\mathrm{ADHD}$ 는 생물학적인 원인을 우선시하기 때문에 가능한 심리 사회적 스트레스에 의한 증상을 구분하려 노력해야 한다. ${ }^{3)}$ 환 아의 증상이 확인이 되었다면 인지능력 및 지능에 대한 평가 가 필요하다. 과제의 성취뿐 아니라 성취하기까지 과정을 평가 해야 하며 환아가 능력을 발휘하는 데 어려움을 겪는 상황들 도 파악해야 한다. 환아가 장애를 보이는 과제가 주로 어떠한 형태인지, 하루 일과 중 더 장애를 겪는 시간대와 아동의 기질 등에 대한 탐색이 필요하다. $\mathrm{ADHD}$ 환아들은 정상 아이들에 비하여 과제 수행 시 주변 환경에 영향을 더 많이 받는데 학교 수업 같은 집단 학습 시 환아는 어떻게 대처를 하고 있는지, 환 아가 겪는 어려움에 대하여 담임 선생님이 어떻게 대처를 하 는지 확인해야 한다. 대인관계의 양상도 확인이 필요하다. $\mathrm{ADHD}$ 환아들의 경우 뜻이 맞지 않는 상황에서 화를 내거나 논쟁하는 성향이 강한 것으로 보고되었는데 이로 인한 대인 관계에서의 어려움 여부도 평가가 필요하다.

국내에서 사용 가능한 면담 도구는 구조화되어 일반인도 사 용할 수 있는 Diagnostic Interview Schedule for ChildrenIV(DISC-IV)와 반구조화된 면담 도구로 교육을 받은 숙련된 평가자가 시행하는 Kiddie-Schedule for Affective Disorders and Schizophrenia-Present and Lifetime Version과 같은 반 구조화 면담 도구가 있다. 두 가지 면담 도구 모두 각각 2007 년, ${ }^{4)}$ 2003년 ${ }^{5)}$ 에 한국어판 표준화 작업이 진행되었다.

다른 흔한 공존 정신 장애(Other common psychiatric disorder)

$\mathrm{ADHD}$ 환아에서 흔한 공존 질환은 발달단계에 따라 변화 하므로 연령에 따라 주의해야 할 공존 질환이 달라진다. 초기 아동기의 경우 적대적 반항장애, 언어장애, 유뇨증 등이 흔하 고 많은 수의 아동들은 특정학습장애를 보인다. $\mathrm{ADHD}$ 환아 
들은 일반 아동들에 비하여 경계선 지적 장애와 지적 장애의 가능성이 2 3배 높은 것으로 보고되었다. 학령기 중기 이후에 는 불안장애와 틱장애가 함께 공존하며 기분장애는 초기청 소년기에 더 자주 관찰된다.

\section{평가척도(Rating scales) 및 평가도구}

행동 평가척도는 면담과 함께 환아의 행동 특성과 증상을 평가할 수 있는 중요한 방법이다. 주로 부모님이나 선생님이 평 가하는 경우가 많지만 청소년의 경우 스스로 자신의 상태를 평가할 수 있어 자가보고형 척도를 사용하기도 한다. $\mathrm{ADHD}$ Rating Scale-IV는 학령기 아동을 평가하기 위하여 DSM 진 단기준에 맞추어 개발되었다. 부모와 교사가 평가하게 되어 있으며 2007년 한국어판의 표준화가 시행되었다. ${ }^{6}$ 아동 행동 조사표(Child Behavior Checklist)는 대표적인 광대역 척도로 써 부모용, 교사용과 청소년 자가보고형이 있으며 이 중 부모 형만 국내 표준화가 되어 있다.

성인 $\mathrm{ADHD}$ 를 평가하기 위한 도구는 현재 증상을 평가하 는 도구와 이전 아동기의 증상을 후향적으로 평가하는 도구로 나누어진다.) 아동기의 증상을 평가하는 도구로는 WenderUtah 평정척도(Wender-Utah Rating Scale) $)^{8}$ 와 자가보고형 으로 ADHD 증상뿐만 아니라 oppositional defiant disorder
(ODD), conduct disorder(CD) 증상도 함께 평가하는 아동기 증상 척도(Childhood Symptoms Scale-Self Report Form) ${ }^{9)}$ 가 개발되어 있다. 현재 증상을 평가하기 위한 도구는 다음과 같다. ADHD 평가척도-IV(ADHD Rating Scale-IV)는 아동 용으로 개발되었으나 성인에게 자가보고나 관찰자보고 형식 으로 사용할 수 있다. 하지만 아동들에게 맞게 만들어진 문 구를 성인에 맞게 면담자가 변경해야 하며 성인에 대한 표준 화 작업은 이루어지지 않았다. Conners 성인 주의력결핍 과 잉행동장애 평정척도(Conners' Adult ADHD Scale)는 국문 으로 번역되어 타당도와 신뢰도가 보고되었고 ${ }^{10)}$ 최근 6 개월 동안의 자신의 증상을 자가평가하게 만들어진 최근 증상 척 도(Current Symptom Scale)도 국문화 번역 및 표준화가 진 행되었다. ${ }^{11)}$ 추가적으로 현재 기능장애의 정도는 Weiss Functional Impairment Rating Scale Self-Report로 평가할 수 있 으나 아직 한국어로 표준화가 되지는 않았다. ${ }^{3)}$ 성인 $\mathrm{ADHD}$ 평가에 사용할 수 있는 척도는 Table 2에 정리하였다.

최근까지 많은 평가도구가 개발되어 사용하고 있지만 증상 척도를 우선으로 진단을 하는 것을 주의해야 한다. 척도를 이 용한 증상의 평가는 증상을 체계적으로 볼 수 있고, 치료 전후 에 증상의 정도 차이를 평가할 수 있지만 부모와 교사가 하는 평가는 주관적인 평가로 진단에 절대적 근거로 사용하는 것은

Table 2. Symptoms checklists and rating scales for adult ADHD ${ }^{291)}$

\begin{tabular}{|c|c|c|}
\hline Name of diagnostic tool & Type of diagnostic tool & Information \\
\hline Adult ADHD Self-Report Scale & Self-report questionnaire & Six question screening tool of the World Health Organization \\
\hline $\begin{array}{l}\text { Conners' Adult ADHD Rating } \\
\text { Scale (CAARS) }\end{array}$ & $\begin{array}{l}\text { Self-report (CAARS-S) and } \\
\text { observer-report (CAARS-O) } \\
\text { questionnaires }\end{array}$ & $\begin{array}{l}\text { Both CAARS are divided into four factor-derived subscales } \\
\text { (inattention/memory problems, hyperactivity/restlessness, } \\
\text { impulsivity/emotional lability, and problems with } \\
\text { self-concept) and three DSM-IV ADHD subscales } \\
\text { (inattentive symptoms, hyperactive-impulsive symptoms, } \\
\text { and total ADHD symptoms) }\end{array}$ \\
\hline $\begin{array}{l}\text { Conners' Adult ADHD Diagnostic } \\
\text { Interview for DSM-IV }\end{array}$ & Structured interview & \\
\hline $\begin{array}{l}\text { Diagnostic interview for ADHD } \\
\text { in Adults, second edition } \\
\text { (DIVA2.0) }\end{array}$ & Structured interview & $\begin{array}{l}\text { The DIVA investigates the DSM-IV criteria and impairment } \\
\text { in five areas of functioning: education, work, social } \\
\text { relationships, social activities/leisure time, partner/family } \\
\text { relationships, and self-esteem }\end{array}$ \\
\hline Wender Utah Rating Scale (WURS) & Self-report questionnaire & $\begin{array}{l}\text { WURS was developed to retrospectively diagnosis childhood } \\
\text { ADHD, as this is required to diagnose adult ADHD includes } \\
\text { symptoms of other, potentially comorbid disorders }\end{array}$ \\
\hline $\begin{array}{l}\text { Brown Attention-Deficit Disorder } \\
\text { Rating Scale (BADDS) }\end{array}$ & Self-report questionnaire & $\begin{array}{l}\text { BADDS only measures behaviors related to executive } \\
\text { functioning and inattention }\end{array}$ \\
\hline Current Symptoms Scale & Self-report questionnaire & Simple DSM-IV based screening instrument \\
\hline ADHD Rating Scale IV & Questionnaire & $\begin{array}{l}\text { Originally developed for children and adolescents. Derived } \\
\text { from DSM-IV diagnostic criteria }\end{array}$ \\
\hline ADHD Self-Report & Self-report questionnaire & Self-reporting questionnaire based on ADHD-RS-IV \\
\hline ADHD Diagnostic Checklist & Diagnostic checklist & Diagnostic checklist based on ADHD-RS-IV \\
\hline
\end{tabular}

ADHD: attention-deficit hyperactivity disorder, RS: Rating Scale 
주의가 필요하다.

\section{심리검사}

주의집중력과 충동성, 지능, 학습능력의 객관적인 평가가 진 단 과정에 도움이 된다.

주의집중력과 충동성을 평가하는 가장 흔한 방법은 지속수 행검사(continuous performance test)이다. ${ }^{12)}$ 표적 자극에 대하 여 주의지속성, 주의 산만성, 충동성 등을 평가하는데 $\mathrm{ADHD}$ 환아의 경우 오경보 횟수, 누락 횟수와 반응시간이 유의미한 차이를 보이고 있어 무관한 자극에 대한 산만함과 주의 집중 지속의 어려움이 있음을 확인할 수 있다. 하지만 지적인 능력 이 우수할 경우 예측도가 낮고 우울이나 불안 같은 다른 정신 과적 질환에 의한 주의력결핍과 산만함을 감별하는 데 한계가 있다. 종합주의력검사(Comprehensive Attention Test)는 일반 아동을 대상으로 개발된 검사로 분할주의력과 작업기억력 등 의 다양한 측면을 고려한 검사로 지속수행검사보다 포괄적인 평가가 가능하며 $\mathrm{ADHD}$ 환아를 대상으로 한 연구에서도 진 단의 유용성이 입증되었다. ${ }^{13}$

지능검사는 $\mathrm{ADHD}$ 와 지적 장애, 학습장애를 감별하는 것 뿐만 아니라 검사하는 동안 환아를 관찰하면서 증상을 확인하 고 검사결과의 유용성도 판정하는 데 도움이 된다. 지능검사의 소항목이 진단의 예측인자가 되는지에 대한 논란이 있는데, 숫 자, 상식, 차례 맞추기 등에서 구별할 수 있다는 보고와 주의집 중과 처리속도 요인지표에서는 유의한 차이가 없었다는 상반 된 보고가 있어 결과 해석 시 유의해야 한다. 하지만 최근 연구 에서 처리속도의 감소가 주의력 결핍과 연관이 있고 ${ }^{14)}$ 언어성 지능이 동작성 지능에 비하여 높다모고 보고되고 있어 이 둘의 차이는 $\mathrm{ADHD}$ 에서 상당히 타당한 소견으로 인식되고 있다.

\section{가족력과 가족 기능 평가}

가족의 양육분위기와 기능을 평가하는 것이 필요하다. 가족 의 성향이나 배경이 $\mathrm{ADHD}$ 의 원인이라고 할 수는 없다. 하지만 가족 구성원의 기능저하는 환아의 증상을 더 심각하게 하고 장애의 정도와 위험을 높일 수 있기 때문에 가족 내 다른 정신 과적 질환에 대하여도 평가가 필요하다. $\mathrm{ADHD}$ 는 $80 \%$ 에서 가족력과 연관이 있는 것으로 보고가 된다. ${ }^{16)}$ 부모와 형제들 에게 우울증, 불안장애, 분노조절 장애, 법을 지키는 것에 대 한 어려움, 약물 및 알코올 남용, 인격장애, 자살 시도 등의 유 무를 확인하고 이러한 경우 가족도 함께 치료에 포함시키는 것이 필요하다.

\section{주산기 및 발달력에서의 위험인자}

환아의 주산기와 발달력에 대한 평가도 필요하다. 임신 중
산모의 스트레스, 조산, 산후우울증의 심각도, 발달 초기 주양 육자의 변화, 첫 문장 말하기의 지연, ${ }^{17)}$ 임신 시 알코올 섭취, 부모의 이혼 ${ }^{18}$ 은 $\mathrm{ADHD}$ 의 위험인자로 보고되었다. 따라서 환 아의 주산기 질환뿐 아니라 양육환경, 주양육자의 당시 정신건 강 상태에 대한 정보의 조사가 이루어져야 한다. 발달의 전반 적인 지연 혹은 언어, 사회성 발달의 지연은 발달 장애의 가능 성을 시사하는데, 많은 발달 장애에서 집중력 문제와 과잉행 동 양상이 동반되기 때문에 이에 대한 확인을 해야 한다.

\section{성인 $\mathrm{ADHD}$ 의 평가}

성인 $\mathrm{ADHD}$ 의 선별에는 World Health Organization(WHO) 에서 공식진단도구로 지정한 Adult Self Report Scale(Version 1.1, 18 item)을 사용할 수 있다. 선별검사에서 양성소견이 나 오면 임상가에 의하여 다른 정신과적 진단이 있는지 감별진 단을 해야 한다. DSM-5에 의하면 반드시 12 세 이전에 진단기 준을 만족하는 증상이 있어야 하며 이는 환자뿐 아니라 가족 등의 정보와 일치해야 한다. 초등학교 과정을 얼마나 잘 이수 했는지에 대한 평가가 좋은 정보가 되는데 이 시기에 장애가 발견되지 않았다면 성인이 될 때까지 장애를 보이지 않을 것 이다. 현재의 증상도 진단기준에 부합해야 하며 그로 인한 일 상 생활의 장애가 발생해야 한다. 때로 환자가 병식이 부족하 고 평가척도에 협조하지 않더라도 면담을 통한 정보가 진단하 기에 충분한 정보가 될 수 있다.

성인에서도 이전 발달력과 다른 정신과적 증상의 유무를 확인해야 한다. 증상이 확인된다면 치료가 필요한 상황여부 와 치료에 대한 반응을 확인해야 하며, 일차적인 증상인지, 이 차적인 증상인지 확인이 필요하다. 성인이 되면서 과잉행동이 줄어들지만 일부 환자에서는 충동적이고 가만히 있지 못하는 증상을 가지기도 하기 때문에 이러한 증상들이 $\mathrm{ADHD}$ 에서 공 존하는 것으로 알려진 반사회성 인격장애, 우울장애, 불안장애 등과의 연관성도 확인이 필요하다.

\section{감별진단}

\section{내과적 진단}

신체검진을 통하여 환아의 신체적 상태를 파악해야 하고 의심되는 진단에 대하여 추가 검사가 필요하다. 신체검진 시 두부손상, 뇌전증, 청력과 시력의 손상, 갑상선 기능, 저혈당, 심한 빈혈, 납중독, fragile X syndrome, 태아 알코올 증후군, 페닐캡티뇨증, 신경섬유종 등에 대한 감별이 필요하며 각각 진단에 대한 감별진단을 위한 검사는 Table 3 과 같다. 대부분 의 $\mathrm{ADHD}$ 환자에서 기질적 문제에 대한 검사가 필요하지 않 지만 특정 환자의 경우 수면다원검사, 뇌파검사와 뇌영상검사 
Table 3. Medical disorders that could possibly mimic ADHD ${ }^{3)}$

\begin{tabular}{|c|c|}
\hline General medical conditions & Investigations confirm the diagnosis of the medical condition \\
\hline Head trauma/concussion & $\begin{array}{l}\text { Since underlying ADHD can increase risk for head trauma, it is important to look for timing of } \\
\text { cognitive symptoms apparition (present before, or appeared or worsened after head trauma) }\end{array}$ \\
\hline Seizure disorders & Neurology assessment confirms diagnosis \\
\hline $\begin{array}{l}\text { Hearing impairment or } \\
\text { vision impairment }\end{array}$ & Audiology and vision evaluation confirms diagnosis \\
\hline Thyroid dysfunction & TSH levels indicate hypothyroidism or hyperthyroidism \\
\hline Hypoglycemia & Abnormally low glucose blood levels confirms diagnosis \\
\hline Severe anemia & $\mathrm{CBC}$ and anemia investigations confirm diagnosis \\
\hline Lead poisoning & Lead blood level measurement confirms diagnosis \\
\hline Fragile $\mathrm{X}$ syndrome & Molecular genetic testing for FMR-1 gene confirms diagnosis. Genotype confirms diagnosis \\
\hline Fetal alcohol spectrum & - Possible presence of intellectual disability \\
\hline \multirow[t]{4}{*}{ disorder (FASD) } & - Growth deficiency and FAS facial features \\
\hline & - Evaluate prenatal alcohol exposure risk \\
\hline & - Magnetic brain imaging \\
\hline & - Psychological assessment (including intellectual, language processing, and sensorimotor) \\
\hline Phenylketonuria & Blood test confirms diagnosis \\
\hline Neurofibromatosis & Café au lait spots \\
\hline
\end{tabular}

ADHD: attention-deficit hyperactivity disorder, $C B C$ : complete blood count, FMR: fragile X mental retardation

Table 4. Psychiatric disorders that could possibly mimic $A D H D^{3)}$

\begin{tabular}{|c|c|}
\hline Conditions that can mimic ADHD & Symptoms or signs not characteristic of ADHD \\
\hline Generalized anxiety disorder & $\begin{array}{l}\text { Worry for six months or more that the person cannot control; lack of energy; } \\
\text { anxious mood and somatic anxiety symptoms. }\end{array}$ \\
\hline Obsessive compulsive disorder & Presence of obsessions or compulsions that interfere with level of function \\
\hline Major depression & $\begin{array}{l}\text { Episodic decline in mood or depressed mood and/or dysphoria; suicide-related issues; } \\
\text { low energy; psychomotor retardation. }\end{array}$ \\
\hline $\begin{array}{l}\text { Bipolar disorder I or II (manic or } \\
\text { hypomanic episode) }\end{array}$ & $\begin{array}{l}\text { Episodic change from baseline; psychotic symptoms; grandiosity; pressured speech; } \\
\text { recent decreased need for sleep. }\end{array}$ \\
\hline $\begin{array}{l}\text { Psychotic disorder (schizophrenia } \\
\text { or schizoaffective disorder) }\end{array}$ & Psychotic symptoms. \\
\hline Autism spectrum disorder & $\begin{array}{l}\text { Qualitative impairment in social interactions, communication or odd eccentric } \\
\text { behaviours }\end{array}$ \\
\hline Oppositional defiant disorder & Defiant; loses temper; annoys others and is easily annoyed; spiteful or vindictive. \\
\hline Conduct disorder & $\begin{array}{l}\text { Presence of conduct disorder criteria e.g. aggression to people and animals; } \\
\text { destruction of property; deceitfulness or theft; serious violations of rules }\end{array}$ \\
\hline $\begin{array}{l}\text { Disruptive mood dysregulation } \\
\text { disorder }\end{array}$ & $\begin{array}{l}\text { Severe recurrent disproportional temper outbursts (verbal and/or physical) occuring } \\
\text { three or more times a week in at least two settings for } 12 \text { months or more. Diagnosis first } \\
\text { made between ages six to ten years. }\end{array}$ \\
\hline Substance use disorder & Urine toxicology screen confirms presence of substance. \\
\hline Learning disorder & Consultation with psychologist or neuropsychologist confirms presence of the disorder \\
\hline Language disorder & Consultation with speech-language pathologist confirms presence of the disorder. \\
\hline Tic disorder/tourette syndrome (TS) & Presence of vocal or motor tics (or both for TS). \\
\hline Borderline personality disorder & $\begin{array}{l}\text { Abandonment anxiety; hourly mood fluctuations; suicidal threats; identity disturbance; } \\
\text { dissociative symptoms or micro psychotic episodes; feelings of emptiness. }\end{array}$ \\
\hline Antisocial personality disorder & Lack of remorse; lack of responsibility; lack of empathy. \\
\hline IQ-related problems: intellectual & Cognitive assessment confirms diagnosis \\
\hline disabilities gifted child & $\begin{array}{l}\text { Note: If IQ is within the normal range: explore whether curriculum is not well matched } \\
\text { to child's ability. }\end{array}$ \\
\hline
\end{tabular}

ADHD: attention-deficit hyperactivity disorder 
가 필요할 때도 있다. 뇌전증 환아들의 경우 일반 인구보다 $\mathrm{ADHD}$ 유병률이 2.5배에 달하며 ${ }^{19)}$ 일반 인구에서 뇌전증 유 병률이 $0.5 \%$ 인데 비하여 $\mathrm{ADHD}$ 환아들의 경우 $2.3 \%$ 로 4 배 이상 유병률이 증가하는 것으로 보고되었다. ${ }^{20)}$ 유아기 결여간 질(childhood absence epilepsy)은 동반될 수 있는 정신과적 질환 중 $\mathrm{ADHD}$ 에 가장 큰 영향을 끼치며 부주의형과 가장 많이 동반된다. ${ }^{21)}$ 간질의 조절이 잘 되지 않을 경우 행동 문제 가 심해지는 것으로 보고되었는데 ${ }^{21)}$ 간질의 동반질환 여부 파 악이 환아 행동 조절에 중요할 것으로 생각된다. $\mathrm{ADHD}$ 진단 에 있어 뇌파검사의 활용은 세타밴드(theta band) 활성의 증 가와 세타밴드/베타밴드의 비율이 증가되는 것이 보고되면서 관심이 증가하였다. ${ }^{22,23)}$ 하지만 정상 뇌파를 보이는 $\mathrm{ADHD}$ 환아의 비율이 16 18\%로 보고되면서 ${ }^{23,24)}$ 아직 진단적 정확성 은 확보되지 않았다.

\section{정신과적 진단 ${ }^{25)}$}

$\mathrm{ADHD}$ 와 함께 동반되어 있거나 $\mathrm{ADHD}$ 의 증상과 비슷한 양 상을 보이는 진단에 대하여 감별이 필요하다. 동반된 정신과 질환이 있다면 $\mathrm{ADHD}$ 증상에 의하여 이차적으로 발생하였 는지 독립적으로 발생하였는지 함께 발병하였는지 주의 깊게 확인해야 한다. 감별해야 할 진단과 감별점은 Table 4 와 같다.

\section{임상 양상}

\section{역 학}

\section{학령전기}

학령전기 아동의 $\mathrm{ADHD}$ 에 대한 연구는 학령기에 비해 상대 적으로 많지 않으며, 만 4세 이전의 진단에 대해서는 정상 범 주의 행동과 구분하는 것에 대한 어려움이 있지만 ${ }^{1)}$ 최근 학령 전기 아동의 진단의 안정성에 대한 연구에서는 학령전기 $\mathrm{ADHD}$ 로 진단받은 환아들이 학령기까지 진단이 이어지는 것 으로 보고하고 있어 학령전기 $\mathrm{ADHD}$ 진단의 안정성에 대한 증 거들이 제시되고 있다. ${ }^{26,27)}$ 학령전기 $\mathrm{ADHD}$ 학령전기 $\mathrm{ADHD}$ 의 유병률은 2.0 7.9\%의 범위로 남아에서 더 많은 것으로 보 고되고 있다. ${ }^{28)}$

\section{학령-청소년기}

$\mathrm{ADHD}$ 의 유병률에 대한 연구들은 진단기준, 정보 출처, 장 애기준 등 연구 방법에 따라서 1 20\%까지 매우 다양한 유병 률을 보고하고 있다. ${ }^{29)}$ 평균적인 유병률에 대해서 DSM-5에 서 아동은 약 $5 \%$, 성인은 약 $2.5 \%$ 의 유병률을 보고하고 있다. Polanczyk 등 ${ }^{30}$ 은 세계적인 유병률을 종합하여 $\mathrm{ADHD}$ 의 유
병률을 5.29\%로 보고한 바 있다. 미국에서는 한 지역의 전체 공립초등학교 아동의 $5.96 \%$ 가 약물치료를 받고 있다는 보고 가 있을 정도로 $\mathrm{ADHD}$ 의 치료가 보편화되어 있다.31) 유병률의 변화에 대해서는 시간이 지날수록 $\mathrm{ADHD}$ 의 유병률이 증가 하고 있다는 연구들이 있으나, ${ }^{32-34)} 30$ 년간의 유병률에 대한 조사를 종합한 연구에서는 시간에 따른 실질적인 유병률의 증가는 없었으며, $\mathrm{ADHD}$ 의 유병률은 5\% 정도로 유병률이 증 가하는 경향성은 $\mathrm{ADHD}$ 에 대한 인식의 증가 때문임을 제시 하였으며, 또한 연구 방법론에 대한 보정을 하였을 때, 전 세 계적으로 $\mathrm{ADHD}$ 유병률의 지역적 차이 역시 크지 않은 것으 로 함께 보고하였다. ${ }^{35}$

유병률에 대한 국내의 연구 역시 어떤 진단도구로 평가하였 는지, 지역이 어디인지에 따라 많은 차이를 보이고 있다. 대표 적으로는 2006년 서울 지역의 학생을 대상으로 DISC-IV를 활 용한 구조화된 부모면담을 통해 확인된 $\mathrm{ADHD}$ 유병률은 초 등학교에서 약 $13 \%$ 였고, 중학생과 고등학생에서는 $7 \%$ 내외였 다. 다른 역학 연구들로는 시골지역의 초등학생을 대상으로 한 연구에서 $1.99 \%$ 의 유병률이 보고된 바 있으며 ${ }^{36)}$ 서울과 대전에서 4학년에서 6학년까지 780명의 초등학생을 대상으로 한 연구에서는 $7.6 \%$ 의 유병률을 보고하였다. ${ }^{37)}$ 서울 지역 4 개 초등학교의 2429 명의 학생을 대상으로 한 역학연구는 $6.5 \%$ 의 유병률을 보고하였으며 ${ }^{38)}$ 시화 반월 공단 지역의 초등학생 을 대상으로 한 연구에서는 $9.4 \%$ 의 높은 유병률을 보고하기 도 하였다. ${ }^{39)}$

하위 유형별 유병률에 대한 메타분석에서는 전체 $5.9 \%$ 의 $\mathrm{ADHD}$ 환자 중 혼합형이 $3.4 \%$ 로 가장 많고, 부주의형 $1.8 \%$, 과잉행동형 $0.8 \%$ 의 순으로 나타났으며 ${ }^{40)}$ 다른 연구에서도 혼 합형이 60 70\%, 부주의형 20 30\%, 과잉행동형 5 10\% 순의 유사한 결과를 보고하였다.11)

$\mathrm{ADHD}$ 유병률의 남녀 성비에 대해서는 DSM-5에서는 아동 의 경우 약 2:1, 성인은 1.6:1로 남자에서 더 많은 것으로 보고 하였으며, 여성의 경우 남성보다 부주의 증상을 더 많이 보이 는 것으로 보고하였다. ${ }^{1)}$ 남녀 성비에 대한 다른 연구에서도 약 3.2:1 정도로 남자에서 더 흔한 것으로 보고하였으며, 과잉 행동형의 경우 성비가 3.5:1 정도로 높았으나, 부주의형은 1.8:1 정도로 낮아져 역시 여성은 과잉행동보다는 부주의 증상이 더 많은 것으로 보고되었다. ${ }^{40)}$

$\mathrm{ADHD}$ 의 발병연령에 대해서는 DSM-IV에서 DSM- 5 로 바 뀌면서 진단기준이 7세에서 12 세로 바뀌고, 17 세 이상에서는 과잉행동 증상의 충족 개수가 6 가지에서 5 가지로 줄어들어 고 연령에서의 발병을 포함하는 발달적 고려가 이루어졌다.) 발 병연령에 대한 연구에서는 7세 이전의 발병비율과 10 세 이전의 발병비율을 각각 $91.6 \%, 97.0 \%$ 로 보고하여 여전히 대부분의 
환아들은 학령기 초기 이전에 발병하는 것으로 보고되었다.40)

성인기

성인의 경우 과거에는 성인 $\mathrm{ADHD}$ 가 흔하지 않은 것으로 생 각되었으날) 최근에는 성인의 $\mathrm{ADHD}$ 증상에 대한 관심으로 연구가 활발해지면서 많은 환자들이 성인기까지 $\mathrm{ADHD}$ 증상 이 지속되는 것으로 보고되고 있다. 성인 ADHD 유병률은 1 $5 \%$ 까지 다양하게 보고되고 있으며, 평균 $2.5 \%$ 의 유병률이 보 고되고 있다.,43) 미국의 18 44세 성인 3199명을 대상으로 시 행한 연구에서는 $4.4 \%$ 의 유병률을 보고하기도 하였다.44) 국내 에서는 6124명을 대상으로 한 연구에서 성인 ADHD의 6개월 유병률을 $1.1 \%$ 로 보고하였으며,5) 2172 명의 대학생을 대상으 로 한 연구에서는 $7.6 \%$ 의 유병률을 보고한 바 있다. ${ }^{46)}$

아동기의 $\mathrm{ADHD}$ 가 성인기까지 지속되는 비율에 대해서는 $\mathrm{WHO}$ 의 다국가 자료에 기반한 연구에서 평균 $50 \%$ 의 성인기 지속 이환율을 보고하였으며, ${ }^{47)}$ Kessler 등 ${ }^{48)}$ 은 $45.7 \%$ 의 성인 기 지속이환율을 보고하여 대개 $50 \%$ 정도의 지속이환율이 보 고되고 있다. ${ }^{1)}$ Faraone 등 ${ }^{49}$ 은 부분 관해까지 포함하였을 때, 약 2/3의 아동기 $\mathrm{ADHD}$ 환자가 성인기까지 증상이 이환되는 것으로 보고한 바 있다.

성인기 $\mathrm{ADHD}$ 의 증상은 영역별로 차이를 보이는데, 과잉행 동 증상이 많이 호전되는 것에 비해 부주의와 충동성은 더 문 제가 되는 것으로 보고되고 있어 ${ }^{1)} \mathrm{Kessler}$ 등 ${ }^{48)}$ 은 성인기 $\mathrm{ADHD}$ 의 환자의 경우 과잉행동은 $34.6 \%$ 의 환자가 증상을 나 타낸 반면, 부주의 증상은 $94.9 \%$ 의 환자가 증상을 나타낸 것 으로 보고하였다.

아동기에 발병한 환자는 성인이 되어서 증상의 수준이 호전 되더라도 여전히 $90 \%$ 정도의 환자가 기능의 어려움을 겪는 것 으로 보고되고 있어 ${ }^{50)}$ 더 많은 교통법규 위반, ${ }^{51)}$ 부정적인 결혼 생활,52) 더 많은 범죄행위, ${ }^{53)}$ 낮은 직업적 성취, ${ }^{54)}$ 생산성 저하 ${ }^{55)}$ 등을 보이는 것으로 나타났다.

\section{원 인}

\section{유전적 요인}

$\mathrm{ADHD}$ 는 신경발달학적 장애로 유전적 영향을 많이 받는 것으로 알려져 있다. $\mathrm{ADHD}$ 의 유전에 대한 연구는 초기 가계 도 연구, 쌍생아 연구와 후보유전자에 대한 연구 및 유전체 전 체에 대한 연구에 이르기까지 다양한 방식으로 연구되고 있 다. 가계도 연구를 통해서 알려진 ADHD 일차친족의 위험률 은 15 60\% 정도로 알려져 있으며, 상대 위험도 역시 2 6배로 매우 높은 것으로 알려져 있다. ${ }^{56}$ 가계도 연구를 통해 $\mathrm{ADHD}$ 환자의 친족 가운데 $\mathrm{ADHD}$ 를 포함하여 품행장애, ${ }^{57)}$ 소아기
발병 양극성 장애, ${ }^{58}$ 자폐 장애 등 ${ }^{59}$ 이 함께 유전되는 위험이 높은 것으로 보고되고 있다. 많은 쌍생아 연구에서도 $\mathrm{ADHD}$ 의 유전율에 대해 $76 \%$ 로 매우 높은 수준의 유전율을 보고한 바 있다. ${ }^{60)}$

$\mathrm{ADHD}$ 의 원인유전자에 대해서는 다양한 후보유전자들에 대한 연구가 이루어졌는데, 주로 도파민(DAT1, DRD4, DRD5), 세로토닌(5-HTT, HTR1B), 아드레날린(DBH, ADRA2) 및 니 코틴(CHRNA4)의 신경전달 및 수용체와 관련된 유전자와 함 께 신경발달에 관련된 유전자들(SNAP25, BDNF)에 대한 증 거들이 제시되었다. ${ }^{61)}$ 그러나, $\mathrm{ADHD}$ 의 후보유전자들에 대한 증거가 충분히 재현되지 않고, 위양성의 가능성도 높아서 후보 유전자 연구에 대한 회의적인 시각이 제시되고, 더불어 최근 유전체의 염기서열 분석 기술이 발달함에 따라 전장 유전체 연 관(genome wide association study) 분석을 통해 ADHD의 유전자를 찾으려는 시도가 많아지기 시작했다. ${ }^{61)}$

전장 유전체 연관분석을 통한 2008년의 한 메타분석에서는 16 번 염색체에 $\mathrm{ADHD}$ 의 감수성 유전자 좌위가 있을 것이라 고 보고한 바 있다. ${ }^{62)}$ 또한 최근 60000여명을 대상으로 한 대 규모 연구에서는 $\mathrm{ADHD}$, 자폐성 장애, 주요우울장애, 양극성 장애, 조현병에 대한 전장 유전체 연관성 분석을 시행하였으 며, 이를 통해 $\mathrm{ADHD}$ 와 주요우울증이 유전적 연관성을 가지 는 것으로 보고하였으며, $\mathrm{ADHD}$ 의 유전율을 0.28 (single nucleotide polymorphism heritability)로 보고한 바 있다. ${ }^{63)}$ 전 장 유전체 연관성 분석은 아직 충분한 연구가 축적되지 않았 고, $\mathrm{ADHD}$ 의 원인유전자에 대한 유전적으로 유의미한 결과 를 보여주지 못하고 있다. ${ }^{64)}$ 심지어 기존 후보유전자 연구를 통해 알려진 유전자들도 연관성 분석에서 유의미한 결과를 보여주지 못하고 있다. ${ }^{65}$ 그러나, 전장 유전체 연관분석은 $\mathrm{ADHD}$ 의 원인유전자를 규명하는 데에 혁신적인 도구로 더 많은 연구가 필요할 것으로 생각된다.

\section{환경적 요인}

$\mathrm{ADHD}$ 와 관련될 수 있는 환경적 변인에 대해서는 매우 다 양한 태아기 독성 물질의 노출, 중금속, 화학물질 노출, 영양 적 요인, 심리사회적 요인들에 대한 연구가 이루어지고 있다. 각 변인들에 대해 많은 연구가 이루어지고 있으며, 각 변인들 에 따라서 일관되게 $\mathrm{ADHD}$ 와의 연관성에 대한 증거가 제시 되고 있는 변인도 있으며, 서로 상반된 결과로 충분한 증거가 제시되지 못하고 있는 변인도 있다. ${ }^{66)}$ 예를 들어 영양소 섭취 와 납 중독, $\mathrm{TV}$ 시청 등은 과거 $\mathrm{ADHD}$ 와 연관성이 있을 것으 로 생각되었으나, 후속 연구에서 상반되는 연구 결과들로 인 해 연관성에 대한 증거가 충분치 않은 것으로 나타났다. 반면 polychlorinated bipheny에의 노출, 태아기의 알코올 노출, 태 
아기 모체의 흡연 등은 $\mathrm{ADHD}$ 와의 연관성에 대한 일관된 증 거들이 제시되고 있으며, 난산과 심리사회적 역경 등은 $\mathrm{ADHD}$ 와의 연관성에 대한 부분적 증거들이 제시되고 있다.

\section{임상양상 및 경과}

$\mathrm{ADHD}$ 의 특징적인 증상들은 일반적으로 5세 이전에 시작 되며, 상당부분은 청소년 및 성인기까지 지속된다. ${ }^{67}$

\section{핵심증상}

과잉행동

과잉행동은 $\mathrm{ADHD}$ 의 핵심증상 중 하나로 과도하게 자리 를 뜨고 돌아다니거나 몸을 꼼지락거리며 쉴 새 없이 움직이 는 양상을 나타내며, 성인의 경우 안절부절하지 못하는 모습 을 보이기도 한다.1) 과잉행동 증상은 부주의 증상보다 일찍 나타나는 편으로 학령전기나 학령기 초기에 주로 처음 관찰 되게 된다. ${ }^{68,69)}$ 많은 부모들이 유아시기에 과다행동을 관찰하 게 되지만, 만 4세 이전에는 이것이 나이에 적합한 정상 범주 의 행동인지 $\mathrm{ADHD}$ 에 준하는 병적인 증상인지를 구분하는 것은 어렵다. ${ }^{1,0)}$ 더욱이 장소에 따라 증상이 다르게 나타나기 때문에 좀 더 정확한 평가가 필요하게 되며, 학교와 가정에서 동시에 안정적인 평가가 가능한 학령기 초기에 대체로 진단 을 받게 된다. 곽ㅇ잉행동은 나이가 들면서 호전되는 경과를 보 여 청소년기나 성인기가 되면 진단기준을 만족하지 않을 만큼 좋아지는 경우가 많다.) 6 15세의 소아청소년을 대상으로 시 행한 한 연구에서는 과다행동의 경우 $6 \%$ 만이 호전되지 않는 만성경과를 보이는 것으로 보고하기도 하였다. ${ }^{72)}$ 이런 경과는 연령에 따라 진단의 하위유형에 변화를 가져오는데, 학령기 초 기에는 과잉행동형의 비율이 사춘기에 비해 더 많이 나타나며, 나이가 들면서 과잉행동이 호전되면 혼합형의 진단이 부주의 형으로 바뀌는 환자가 생긴다. ${ }^{73)} \mathrm{ADHD}$ 는 증상별로 성별의 차 이를 보여 과잉행동형의 경우 여아보다 남아에서 더 많은 것으 로 보고되고 있다. ${ }^{74}$ 과잉행동은 외현화 증상으로 인해 사회적 문제를 일으키게 되어 혼합형의 경우 부주의형에 비해 학교에 서 더 많은 반사회적 행동으로 문제를 일으키며 ${ }^{75)}$ 반항적 적대 장애나 품행장애가 더 많이 동반될 뿐 아니라 ${ }^{76)}$ 이로 인해 부 모의 양육스트레스를 더 많이 유발하게 된다. ${ }^{77)}$ 또한 과잉행 동 증상으로 인해 과잉행동형과 혼합형은 부주의형에 비해 사고로 인한 더 많은 물리적 손상을 입기도 한다. ${ }^{78)}$

\section{충동성}

충동성은 부주의와는 잘 구별되지만 과잉행동과는 잘 구별 되지 않으며, 하위유형 역시 과잉행동-충동형으로 과잉행동과
함께 분류되어 있다. 충동성은 순서를 기다리기를 힘들어하 여 부적절하게 끼어들거나 질문이 끝나기 전에 대답해 버리는 등의 양상으로 나타난다.1) Kindlon 등 9) 은 충동성을 동기 차 원(motivational domain)과 인지 차원(cognitive domain)의 두 가지로 구분하였다. 동기 차원은 처벌에 대한 민감도와 보 상에 대한 무관심, 수동적 회피 학습, 만족 지연의 요소를 포 함하며, 인지 차원은 억제적 조절과 그 외의 일반적 처리과정 의 결함을 포함한다. 충동성은 과잉행동에 비해서는 조기에 호전되지 않고, 오래 지속되는 경과를 보이는 것으로 보고되 고 있다.1) 이로 인해 여러 가지 사회적 기능의 어려움을 초래할 수 있는데, 305명을 대상으로 7 26세까지 추적관찰한 한 연 구에서는 어린 시절의 품행문제와 과잉행동-충동성이 성인기 에 더 많은 범죄행위를 유발하는 인자이며, 부주의 증상은 범 죄행위에 대한 위험인자가 아님을 보고하기도 하였다. ${ }^{80)}$

부주의

아동은 주의집중을 유지하는 데에 어려움을 느끼며, 외부 자극에 의해 쉽게 산만해져 과제를 끝내지 못하는 모습을 보 인다. 또한 세심한 주의를 기울이지 못해 부주의한 실수를 하 거나, 일상적인 일, 과제, 물건 등을 자주 잊어버리기도 하며, 이야기를 듣지 않는 것처럼 보일 때가 자주 있다. ${ }^{1)}$ 부주의 증 상은 다양한 신경심리학적 기능과 연관성을 가지는데, $\mathrm{ADHD}$ 아동은 일반적 인지능력, 단기기억, 작업기억, 처리속도, 지속 적 주의력, 반응시간 다양성 등의 신경심리학적 영역에서 취 약한 특성을 보인다. 이는 과잉행동 증상과는 크게 관련이 없 으며, 부주의 증상과 강한 연관성을 가지는 것으로 나타났 다. ${ }^{78)}$ 부주의 증상은 과잉행동 증상에 비해 더 늦게 나타나고, 과잉행동에 비해 조기에 호전되지 않아 사춘기 이후에도 지속 되는 경향성을 보인다. ${ }^{50,68,69)}$ 이러한 경향성으로 인해 초기 과잉 행동형으로 진단받은 환아가 나이가 들면서 혼합형으로 진단 받기도 한다. $\mathrm{ADHD}$ 환자들은 또래에 비해 학업성취도가 떨 어지는데, 이는 과잉행동 증상보다는 주로 부주의 증상과 강 하게 연관된 것으로 알려져 있으며 ${ }^{811}$ 이는 과잉행동 증상이 학 령기에 점차 호전되는 반면, 부주의 증상에 수반되는 인지적 특성과 함께 부주의 증상이 조기에 호전되지 않는 경과로 인 해 학업수행에 지속적으로 부정적 영향을 미치는 것으로 생 각할 수 있다. 또한 부주의 형은 혼합형에 비해 더 수동적이 고 덜 공격적으로 자기 주장을 덜 하는 편이며, 적절한 사회 적 행동을 잘 모르는 것으로 보고되기도 하였다. ${ }^{82}$ 


\section{관련 인지기능 결함}

실행기능(Executive function)

많은 연구자들은 $\mathrm{ADHD}$ 의 핵심적인 기능 결함에 대해 연구 해왔으며, 실행기능의 결함이 $\mathrm{ADHD}$ 의 증상을 야기하는 것으 로 파악하였다. ${ }^{83)}$ Welsh와 Pennington ${ }^{84)}$ 은 실행기능에 대해 '미래의 목표를 달성하기 위해 적절한 문제 해결 set를 유지하 는 능력'이라고 정의하였다. 실행기능을 구성하는 하위 인지 적 요소에 대해서는 연구자들이 제시하는 모델에 따라 다소 상 이한 면이 있으나, 대개 1) 억제적 조절(inhibitory control), 2) 간 섭조절(interference control), 3) 작업기억(working memory), 4) 인지적 유연성(cognitive flexibility) 등의 하위 인지 과정을 포함하는 것으로 개념화된다. ${ }^{85)} \mathrm{ADHD}$ 아동들은 반응억제 (reponse inhibition), 경계(vigilance), 작업기억(working memory), 계획하기(planning) 등의 실행기능 영역에서 결함을 보 이는 것으로 보고되었다. ${ }^{86}$

\section{작업기억(Working memory)}

작업기억은 실행기능의 중요한 구성요소일 뿐 아니라 $\mathrm{ADHD}$ 의 내적 표현형으로 많은 연구가 이루어졌다. ${ }^{87)}$ Barkley $^{88)}$ 는 작업기억의 결함이 행동 탈억제(behavioral disinhibition)로 부터 발생하는 이차적인 실행기능 결함의 한 종류라고 주장하 기도 하였으나, 작업기억 모델은 작업기억을 $\mathrm{ADHD}$ 의 핵심적 인 내적 표현형으로 제시하고 있다. ${ }^{89)} \mathrm{Baddeley}^{90}$ 의 모델에 의 하면 작업기억은 중앙관리자(central executive), 일회적 완충 기(episodic buffer), 음성학적 기억과 시공간적 기억을 각각 담 당하는 하위기억체계로 구성되어 있다. 많은 연구자들에 의해 $\mathrm{ADHD}$ 환아의 경우 대조군에 비해 음성학적 하위기억 및 시 공간적 작업기억이 모두 저하되어 있는 것으로 나타났으며, 메 타분석에서는 특히 시공간적 작업기억의 저하가 더 큰 effect size를 나타내는 것으로 보고되었다. ${ }^{86,87,91)}$

\section{보상체계(Reward system)}

$\mathrm{ADHD}$ 환자들은 변형된 보상체계의 특성을 보이는데, 보상 에 대한 역치가 높아져 있는 특징을 보인다. ${ }^{92)}$ 또한 만족을 지 연시키기가 어렵고 즉각적인 보상을 강하게 선호하여 나중에 더 큰 보상을 받는 것보다 적더라도 즉각적인 보상에 반응하 는 특징을 보인다. ${ }^{93}$ 한 연구에서는 더 즉각적이고, 쉽게 얻을 수 있는 보상에 대한 선호가 교실에서의 과잉행동과 부주의 증 상 등과 상관관계를 보이는 것으로 보고하였다..$^{94}$ 다만 Antrop 등 ${ }^{95)}$ 은 $\mathrm{ADHD}$ 환아들이 기다리는 동안에 시각적 자극을 제 시하는 것이 즉각적인 보상에 대한 선호양상을 감소시킬 수 있다고 보고하기도 하였다.
반응시간 변동성(Reaction time variability)

$\mathrm{ADHD}$ 에 대한 신경생리학적 연구 결과 중 일관되게 신뢰성 있는 결과를 보여주는 지표 중의 하나가 $\mathrm{ADHD}$ 환자들에서 반응시간 변동성이 증가한다는 것이며 ${ }^{96)}$ 이는 소아 ${ }^{97}$ 와 성인 에서 ${ }^{98)}$ 공통되게 증가하는 것으로 보고되고 있다. 반응시간 변동성이 증가하는 것은 $\mathrm{ADHD}$ 에서만 특이적인 것은 아니며, 자폐 장애, ${ }^{99}$ 조현병, ${ }^{100)}$ 정신병적 증상을 동반한 양극성 장 애, ${ }^{101)}$ 외상적 뇌손상 ${ }^{102)}$ 등에서도 관찰되는 소견이다. $\mathrm{ADHD}$ 의 하위유형에 따른 반응시간 변동성의 차이에 관해서는 메 타분석을 통해 혼합형과 과잉행동형의 경우는 차이가 없으며, 부주의형은 혼합형보다는 다소 낮은 것으로 드러났다. 또한, 정신자극제로 치료한 후에는 반응시간 변동성이 현저히 감소 하는 것으로 보고되기도 하였다. ${ }^{103)}$

감정기능

$\mathrm{ADHD}$ 에서 인정되는 또 하나의 기능적 결함 중 하나가 감정 기능의 결함이다. ${ }^{104)}$ 감정기능은 크게 감정의 인식 기능과 감정 의 조절 기능으로 나눌 수 있는데, $\mathrm{ADHD}$ 환자들은 감정 인식 기능의 결함 ${ }^{105)}$ 과 함께 감정 조절 기능의 결함을 함께 보이는 것으로 나타났다. ${ }^{106}$ 감정 조절 기능의 결함에 대해서 Barkley ${ }^{107)}$ 는 감정 조절의 결함이 억제적 조절의 일차적 결함에서 파생되 는 이차적 문제라고 논하기도 하였으나, 다른 후속 연구들 ${ }^{108,109)}$ 에서는 $\mathrm{ADHD}$ 환자들의 감정적 기능의 결함이 신경심리학적 인지기능의 결함과는 독립적인 것임을 지지하는 증거를 제시 하였다.

\section{시간감각(Sense of time)}

시간감각은 다차원적인 과정을 포함하는 개념으로 시간지 각(time perception), 운동 동기화(motor timing), 시간 예측 (time estimation), 시간생산-재생산(time production-reproduction) 및 일상 생활에서 시간의 사용(use of time in natural settings) 등을 통해 시간감각에 대해 측정하려는 연구들이 이루어졌다. ${ }^{10)}$ 연구 방법론상의 차이들로 인해 명확하게 일관 된 결론은 내리기 어렵지만, 많은 연구들이 대조군과 $\mathrm{ADHD}$ 환아 간에 시간 길이 감별(duration discrimination), 시간 길이 재생산(duration reproduction), 시간 예측(time estimation) 등 여러가지 시간감각 척도에서 유의미한 차이가 있음을 보여 주고 있다.111) 또한 뇌영상 연구를 통해서 소뇌, 기저핵, 전전두 엽 피질 등 시간정보처리(temporal information processing) 와 관련된 뇌영역들이 $\mathrm{ADHD}$ 환아에서 시간감각의 어려움 과 관련되어 있는 것으로 보고되고 있다. ${ }^{111}$ 


\section{뇌영상 연구}

\section{$\mathrm{ADHD}$ 개념의 변화에 따른 뇌영상 연구의 변화}

$\mathrm{ADHD}$ 의 역사를 살펴보았을 때 현재 사용이 되고 있는 $\mathrm{ADHD}$ 라는 정의는 20세기 중반에 형성되었으며, 20세기 초 반에만 하더라도 임상가들은 뇌염과 같은 뇌손상뿐만 아니라 출산 시 관찰되는 여러 질환이나 환경적인 영향으로 인해서 $\mathrm{ADHD}$ 질환이 생긴다고 가정하여 '미세두뇌손상(minimal brain damage)' 또는 '미세두뇌기능장애(minimal brain dysfunction, MBD)'라는 용어를 사용하여 산만하고 활동적이며 충동조절/인지기능의 장애를 보이는 아이들을 명명하였다. 이 러한 개념을 뒷받침하기 위해 시행되었던 뇌영상 연구를 살펴 보면 Bergström과 Bille ${ }^{1122}$ 가 46 명의 $\mathrm{MBD}$ 를 가진 소아를 대 상으로 CT 촬영을 실시한 결과 약 32\%(15명)에서 대뇌수축, 비대칭, 이상소견 등이 관찰되었으며, 44 명의 $\mathrm{MBD}$ 환아들을 대상으로 시행한 다른 연구에서는 $4.5 \%$ 에서 비정상 소견이 관 찰되었다. ${ }^{113}$ 하지만 20세기 중반 이후 $\mathrm{ADHD}$ 를 소아의 뇌손 상에 의한 단일 증후군이라고 생각하는 개념에 대해서 많은 비판이 제기되면서 결국 $\mathrm{ADHD}$ 의 개념을 설명하는 용어는 관 찰가능하고 보다 정확히 명명할 수 있는 '학습장애/행동장애 (learning/behavioral disabilities), '과잉운동(hyperactivity)' 그리고 '과잉운동아증후군(hyperactive child syndrome)'으 로 변경되었다. 이후 특별히 뇌손상이 발견되지 않음에도 유 전적으로 혹은 선척적으로 발견될 수 있다는 개념이 확산되 었고 과학의 발전으로 뇌영상 측정 기술이 향상됨에 따라 다 양한 $\mathrm{ADHD}$ 의 뇌영상 연구 결과들이 발표되고 있다. 이후 시 행된 연구들에서는 전전두엽과 기저핵등이 주목받기 시작하 였으며 이러한 부위의 기능이상이 $\mathrm{ADHD}$ 질병과 연관된다는 연구들이 다수 발표되었다. ${ }^{114)}$ 전전두엽과 기저핵은 상호 밀접 한 연관을 맺고 있다고 알려져 있으며, 기능적 상호작용을 하 고 있고, 기저핵은 $\mathrm{ADHD}$ 와 관련이 깊은 신경전달 물질인 도 파민이 주된 신경물질로서 관여하는 영역이기도 하여 많은 관 심을 받아왔다. 비교적 일반적으로 관찰되는 소견으로는 정상 적으로 존재해야 할 미상핵의 비대칭성이 소실되었거나 역전 이 되어 있다는 것이다. 하지만 이러한 초기 영상 연구 결과들 은 대조군이 확보되지 않은 채 이질적인 집단을 대상으로 시 행되었거나 영상획득 기술의 부족으로 인해서 해상도가 낮다 는 단점이 있었다. ${ }^{115)}$ 이러한 개념의 변화와 더불어 영상 획득 기술의 발달에 따라 ADHD 영상 연구는 점차 functional magnetic resonance imaging(fMRI), single photon emission computed tomography, diffusion tensor imaging(DTI) 등 으로 변화하는 추세이며, 뇌영상 연구를 통한 뇌의 각 구조 에 대한 지식이 증가함에 따라 $\mathrm{ADHD}$ 에서 보이는 증상과의
연관성 및 기전에 대한 이해도 점차 넓혀지고 있는 실정이다.

\section{최근까지의 뇌영상 연구 결과}

$\mathrm{ADHD}$ 아동을 대상으로 뇌영상을 이용한 연구는 많이 진행 되어 왔으나 $\mathrm{ADHD}$ 의 명확한 기전을 설명하거나 예후나 치료 반응을 예측하기에는 부족한 상태이다. 뇌영상 연구에서 주된 관심 부위는 앞서 언급한 바와 같이 실행기능 및 $\mathrm{ADHD}$ 의 병 인과 관련되었다고 생각되는 전전두엽4,116,117)과 기저핵8,118-120) 그리고 최근 들어서 새롭게 주목받고 있는 인지와 운동기능에 서 중요한 역할을 담당한다고 알려진 소뇌 ${ }^{116,121,122)}$ 이다. 전전두 엽의 경우 체적의 감소, 비대칭성이 소실되며, 기저핵의 경우에 도 체적의 감소가 관찰되었으며 이는 실행기능과 반응억제과 제 수행과 연관성을 보였다. 소뇌에서는 위쪽 소뇌의 충부 (superior cerebellar vermis) 부위의 진행되지 않는 용적 감소 가 지속적으로 관찰되었으며 이러한 용적의 감소는 임상적인 경과에 의해 영향을 받지 않았으나, 충부 후하엽(vermis posterior inferior lobe VIII-X)의 용적 감소는 치료 유지 시에 감 소되는 등 다소 가소적인 변화양상을 보이는 것으로 밝혀졌 다. ${ }^{123-125)}$ 결국 이러한 결과는 충부 후하엽의 용적 감소는 보다 질병의 상태를 반영하는 인자로서 임상적인 치료의 타깃으로 사용할 수 있는 가능성을 시사하는 결과라고 볼 수 있다. 또한 경과에 따른 163 명의 $\mathrm{ADHD}$ 소아를 대상으로 평균 5.7년 동 안 경과 관찰하여 시행한 영상 연구에 의하면 $\mathrm{ADHD}$ 소아에 서 대뇌피질이 대조군에 비해서 전반적으로 얇아져 있었고, 그 중에서도 특히 위쪽 전전두엽 부위(superior prefrontal region) 와 중심앞고랑 부위(precentral region)가 특히 두드러진 두께 감소를 보였다. 특히 임상적으로 경과가 안 좋은 환아들의 경 우 좌측 중심 전전두엽 피질에서 고정된 두께의 감소를 관찰 할 수 있었고, 우측 두정엽의 경우 임상적 경과에 따라 증상 이 완화되면 두께가 대조군에 가까워지는 경향을 보였다. ${ }^{126)}$

fMRI 연구에서는 선조체, ${ }^{127,128)}$ 측두엽, ${ }^{129)}$ 전대상회, ${ }^{130)}$ 소뇌 충부 영역 ${ }^{44}$ 의 활성화 이상이 관찰되었다. 최근에는 앞서 살펴 본 구조적 이상뿐만 아니라 뇌 연결성의 이상이 $\mathrm{ADHD}$ 의 주요 병태생리로 작용할 수 있다는 개념이 널리 인식되고 있는 상태 이다. 특히 내정상태회로(default mode network, DMN)의 이 상이 $\mathrm{ADHD}$ 에서 관찰된다는 연구 결과들이 제시되고 있다. $\mathrm{ADHD}$ 환자들의 경우 대조군에 비해서 기본 감각 피질(basic sensory cortices)의 휴식상태 활성강도가 증가되어 있다고 보고하였고, 성인 $\mathrm{ADHD}$ 환자 20명을 대상으로 휴식상태의 $\mathrm{fMRI}$ 를 분석한 연구에서는 앞쪽 띠이랑 지역과 다양한 영역 의 $\mathrm{DMN}$ 간의 연결성이 감소되었다고 보고하기도 하였다. ${ }^{131,132)}$ 휴식상태뿐만 아니라 인지적 과제를 수행하는 동안에도 뇌 연결성의 변화는 관찰된다. Rubia 등 ${ }^{133)}$ 은 $\mathrm{ADHD}$ 환아들이 
대조군에 비해서 과제 수행 시에 fronto-stiatao-parieto-cerebellar connectivity가 감소하고, 기능적 연결성에 있어서 보상 적 증가가 관찰되지 않는다고 보고하였다. 흥미롭게도 이러한 저하된 뇌 연결성은 정신자극제에 의해서 정상화되는 결과를 보이기도 하였다.

최근에 주목받고 있는 DTI의 경우 많은 연구가 이루어지지 는 않았지만 여러 연구 ${ }^{134}$ 에서 우측 전두엽, ${ }^{135)}$ 양측 internal capsule, ${ }^{123)}$ 좌측 소뇌 ${ }^{125)}$ 등의 white matter integrity의 이상을 보고하고 있다. Konrad 등 ${ }^{136}$ 은 양측 측두엽 부위의 백질에서 는 fractional anisotropy(FA)가 증가하나 orbitomedial prefrontal 백질과 우측 앞쪽의 띠이랑에서는 $\mathrm{FA}$ 의 감소가 관찰 된다고 보고하였다. 그리고 Ashtari 등 ${ }^{137)}$ 은 $\mathrm{ADHD}$ 아동에서 right premotor, right striatal, right cerebral peduncle, left middle cerebellar peduncle, left cerebellum, and left parietooccipital areas의 FA 감소를 보고하였다. 이러한 소견들은 모 두 기존의 fronto-striatal-cerebellar deficits ${ }^{125,138,139)}$ 을 지지하 는 소견이다. 그 외에도 대부분의 DTI 연구에서 ADHD가 있 는 경우 구조적 연결성 이상을 시사하는 결과들을 반복해서 제시하고 있지만 이러한 연결성 이상이 어떻게 기능적 연결성 이상과 연관되는지 등에 대한 추가 연구가 필요한 상태이다.

\section{공존 질환(Comorbidity)}

$\mathrm{ADHD}$ 에서 보이는 다양한 증상들은 $\mathrm{ADHD}$ 외의 다양한 정신과적 질환에서도 관찰될 수 있으며, $\mathrm{ADHD}$ 환자들의 경 우 절반이상에서 적어도 하나 이상의 정신과적 공존 질환을 가지고 있는 것으로 조사되었다. ${ }^{100,141)}$ 가장 흔히 동반되는 공 존 질환은 적대적 반항장애(ODD)로 $46.9 \%$ 를 차지하였으며, 그 외에 기분장애(mood disorder) 27.9\%, 품행장애(conduct disorder), 배뇨 장애(elimination disorder) $18.5 \%$, 읽기 장애 (dyslexia) 17.6\%, 불안장애(anxiety) 16.7\%, 틱장애 9.5\%였 다. ${ }^{129)}$ 공존 장애가 있는 경우 임상경과, 예후, 약물에 대한 반 응 등에 부정적인 영향을 미치며, 특히 공존 장애의 수가 많을 수록 중추신경자극제의 효과가 떨어지는 것으로 알려져 있기 때문에 공존 장애가 있는 경우 다른 치료전략이 필요하다. ${ }^{1)}$

\section{발달수준에 따른 공존 장애}

오랜 시간 동안 $\mathrm{ADHD}$ 는 주로 소아의 질환이라 생각되어 왔으나 최근의 연구 결과들을 살펴보면 소아기에 $\mathrm{ADHD}$ 를 진단받은 아동의 $10 ~ 60 \%$ 는 성인기까지 증상이 지속되는 것 으로 보고되었으며, 이러한 증상은 일상 생활에 부정적인 영 향을 미치는 것으로 밝혀졌다. ${ }^{142,143)}$ 하지만 최근에 발표된 뉴 질랜드 생애 코호트 연구에 따르면 성인 $\mathrm{ADHD}$ 환자의 $90 \%$ 에서 아동기 $\mathrm{ADHD}$ 의 병력이 없었으며, 신경심리학적 검사와
다인성의 위험인자 등에서 아동기 $\mathrm{ADHD}$ 와 다른 특성을 보 이는 것으로 조사되어 추후 연구가 더 필요한 실정이다. ${ }^{144}$ 성인 의 경우 가장 흔한 공존 질환은 사회공포증, 특정 공포증, 양극 성 장애 $(29.3 \%, 22.7 \%, 19.4 \%)$ 로 $\mathrm{ADHD}$ 를 진단받은 사람들 중 많은 수는 동반된 다른 질환을 가지고 있는 경우가 많아서 진 단에 어려움을 주기도 한다. ${ }^{129,145)}$

$\mathrm{ADHD}$ 자체가 다양한 경과를 보이는 것과 마찬가지로 공존 장애 또한 나이가 증가하고 질병의 경과에 따라서 변화하는 경향을 보인다. 또한 이러한 증상과 공존 장애의 경과에 따른 적절한 개입 유무에 따라서 치료 및 예후의 결과 등이 달라질 수 있으므로 이를 정확히 파악하는 것은 중요하다. 이에 따라 최근 들어서는 공존 질환을 질병의 시간적 발달단계에 따라 pre-comorbidity(temperament factors, sleep disturbance, autism spectrum disorder and atopic eczema), simultaneous comorbidity(enuresis, encopresis, developmental dyslexia), post-comorbidity(tic disorder, depression, suicidality, anxiety disorders, obsessive compulsive disorder bipolar disorder, $\mathrm{CD}$, substance d/o, obesity, personality d/o) 등으로 구분하려는 시도도 있다. ${ }^{129)}$

Preschool ADHD Treatment Study(PATS)의 결과에 따르 면 학령전기의 아이들에 있어서 가장 많이 동반되는 공존 장 애는 적대적 반항장애로 $52.1 \%$ 에서 관찰되었으며, 그 외에도 의사소통 장애(24.7\%), 불안장애(17.7\%) 등이었다. ${ }^{146)}$ 또한 공존 장애가 동반되는 경우 항정신병 약물의 사용이 그렇지 않은 군에 비해서 더 많은 것으로 조사되었다. ${ }^{147)}$

대부분의 $\mathrm{ADHD}$ 진단은 학령기에 이루어지며 학업적인 어 려움이나 교실에서의 문제행동들로 인해서 내원하는 경우가 많다. 학령기의 경우 $\mathrm{ADHD}$ 증상으로 인해서 전반적인 기능에 부정적인 영향을 많이 미칠뿐더러 다양한 공존 질환이 동반 되는 것으로 알려져 있다. $\mathrm{ADHD}$ 를 진단받은 아동 중 약 $70 \%$ 에서 적어도 하나 이상의 공존 질환이 동반되며, 그중 약 $65 \%$ 에서 적대적 반항 행동이 관찰되며, 약 $23 \%$ 의 경우에서 불안 장애가 동반되는 것으로 조사되었다. ${ }^{188)}$ 게다가 $\mathrm{ADHD}$ 증상으 로 인해서 dyscalculia와 같은 학습장애가 동반되어 학교생활 에 문제를 일으키기도 한다. ${ }^{149)}$ 특히 니코틴과 같은 물질 남용 이 $\mathrm{ADHD}$ 가 동반되지 않은 군에 비해서 높은 비율로 관찰되 며 향후 성인기에 다른 약물의 남용과 연관될 수 있어서 이를 예방하는 것이 필요하다. ${ }^{150)}$

사춘기에 접어 들면서 $\mathrm{ADHD}$ 환아들은 적응장애, 적대적 반항장애/품행장애, 불안장애, 물질 남용, 기분장애, 틱장애 등의 공존질환을 보이는 것으로 조사되었다. ${ }^{151)}$ 특히 기분장 애가 자주 동반되며, Gary 등은 $\mathrm{ADHD}$ 가 동반되는 경우 양극 성 장애의 첫 번째 기분삽화의 연령이 낮아지며 기분장애의 
가족력이 있는 경우에 $\mathrm{ADHD}$ 가 동반되는 경우 향후 양극성 장애로 발전할 가능성이 높다는 연구 결과를 발표하기도 하였 다. ${ }^{152)}$ 우리나라의 경우 스마트폰의 보급에 따라서 언제 어디 서나 인터넷의 사용이 가능하고 따라서 충동조절의 어려움이 있는 $\mathrm{ADHD}$ 환아들의 경우 더욱 문제가 되고 있는 실정이다. 실제로 연구 결과에 따르면 인터넷 중독을 진단을 받은 경우 그렇지 않은 경우에 비해서 더욱 심한 $\mathrm{ADHD}$ 증상을 보였으 며, 우리나라의 경우에도 인터넷 중독을 진단받은 12 명의 아 동 중 7명이 $\mathrm{ADHD}$ 로 동시 진단되기도 하였다. ${ }^{153,154)}$ 그리고 사춘기에 접어 들면서 $\mathrm{ADHD}$ 진단을 받은 환아들의 경우 적 절히 치료받지 못한 경우 $\mathrm{ADHD}$ 관련 증상으로 인해서 학업 성적의 저하 등을 보이는 것으로 관찰되었다. 전체 학업성적뿐 만 아니라 ADHD가 없는 아이들에 비해서 또래나 교사들의 평 가 또한 부정적인 경우가 많았다. ${ }^{155)}$

$\mathrm{ADHD}$ 가 사춘기를 거쳐 성인기에 이르면 매우 다양한 경과 를 보이며 공존 장애 또한 다양하게 관찰된다. 일반적으로 알 려진 바에 의하면 과잉행동, 충동성 등의 $\mathrm{ADHD}$ 증상은 감소 하나 부주의함과 같은 증상은 지속적으로 관찰된다. 많은 연 구에서는 성인기까지 $\mathrm{ADHD}$ 진단이 유지되는 비율은 대략 $15 \%$ 정도이나, 남아있는 $\mathrm{ADHD}$ 연관 증상으로 인한 기능장애 를 보이는 비율이 전체 환자군 중 50 65\%에 이른다고 보고 하고 있다. ${ }^{156)}$ 성인기 $\mathrm{ADHD}$ 환자들은 제한된 시간을 활용하 는 것의 어려움, 좌절에 대한 조절능력의 감소, 자가 동기 부 여의 어려움 등의 임상적 특징을 보인다. ${ }^{157)}$ 이러한 특징으로 인해서 대인관계, 직업유지 등의 측면에서 어려움을 보인다. 공존 장애로는 물질 남용, 정서 장애, 불안장애, 반사회적 인 격장애, 경계성 인격장애 등에 대해서 보고하고 있으며 이러한 공존 장애로 인해서 직장, 가정, 그리고 사회적 관계에서 지속 적인 문제를 일으키게 되어 사회적 그리고 정서적으로 부정적 인 영향을 미치는 것으로 조사되었다. ${ }^{158)}$ 또한 공존 질환의 진 단과 관련된 요인들로는 남자, 더 많은 $\mathrm{ADHD}$ 증상, 낮은 사 회경제적 수준 등이 조사되었다. ${ }^{159}$

\section{적대적 반항장애와 품행장애}

적대적 반항장애는 가장 흔히 $\mathrm{ADHD}$ 와 연관되는 질환이 다. ${ }^{160,161)} \mathrm{ADHD}$ 가 없는 경우에 품행장애의 유병률은 매우 낮 은 편이나 $\mathrm{ADHD}$ 가 있을 경우 20 45\%에서 품행장애의 진단 기준을 만족한다. $\mathrm{ADHD}$ 와 적대적 반항장애가 동반되는 경 우 적대적 반항장애의 진단은 유지되는 경향을 보였으며, 주요 우울증, 품행장애, 반사회적 인격장애 등의 다른 질환의 위험 인자로 작용하였다. ${ }^{162,163)}$ 또한 품행장애가 동반되는 경우 약물 사용장애, 흡연, 양극성 장애의 위험성과 연관성을 보였다. ${ }^{48)}$ 쌍둥이 연구를 비롯하여 원인론에 대한 연구가 진행된 결과,
몇몇 연구에서는 $\mathrm{ADHD}$ 와 품행장애 간에 공유하는 유전적인 변이들을 발견하기도 하였으며, 품행장애가 단독으로 있는 경 우와 달리 $\mathrm{ADHD}$ 가 동반되는 경우에는 $\mathrm{ADHD}$ 의 심한 표현 형이라는 주장도 제기되고 있다. ${ }^{164,165)}$

$\mathrm{ADHD}$ 아동의 경우 대인관계 문제를 포함한 주요한 사회적 인 기능이상을 보이는 경우에 인격장애 대신 품행장애 진단을 내리는 경우가 많지만, 성인기까지 이러한 증상이 나타나는 경 우 많은 수에서 반사회적 인격장애 진단이 내려지게 된다. ${ }^{129,166)}$ $\mathrm{ADHD}$ 와 적대적 반항장애 또는 품행장애가 동반되는 경우 각 각이 있는 경우보다 나쁜 예후를 보이는 것으로 조사되었다. ${ }^{167}$

\section{우울증과 자살}

전체 $\mathrm{ADHD}$ 아동들 중 10 40\%에서 우울증의 진단기준을 만족하게 되며, $\mathrm{ADHD}$ 발병이후 수년 정도 시간이 지난 후에 동반되는 경향을 보인다. 특히 $\mathrm{ADHD}$ 여자 아동의 경우 주요 우울장애로 진단받을 확률이 남자 아동에 비해서 5.4배 높고, $\mathrm{ADHD}$ 진단 전에 우울증으로 치료 받을 가능성이 3 배가량 높 은 것으로 조사되었다. ${ }^{44)} \mathrm{ADHD}$ 에 우울증이 동반될 경우 우울 증의 이른 발병, 긴 이환 기간, 자살 및 입원기간의 증가와 관 련된다. ${ }^{168)}$ 또한 적대적 반항장애/품행장애가 있는 경우가 그 렇지 않은 경우에 비해서 우울증이 더 많이 발병하고 기능을 더욱 떨어뜨리는 것으로 조사되었다. ${ }^{169)} \mathrm{ADHD}$ 의 치료 중에 정신자극제는 때때로 짜증스러움, 불안정한 기분변화를 동반 하기도 하지만 전반적으로 봤을 때 $\mathrm{ADHD}$ 에 대한 약물치료 를 할 경우 우울증 증상의 발현을 지연시키거나 보호하는 역 할을 하는 것으로 밝혀졌다. 특히 경도 또는 중등도 우울증 상이 동반된 ADHD에 대해서 methylphenidate(MPH)의 사 용은 효과적이었다. ${ }^{170,171)}$ 환경적인 영향으로 인한 이차적 우울 증과 생물학적/유전적 요인과 연관된 일차적인 우울증을 구 분하는 것은 향후 치료 방침의 설정과 관련하여 중요하다.

자살의 위험성을 높이는 요인으로는 품행장애, 물질 남용, 인지적 장애, 과잉행동이 있는 경우 등이 있었으며, 성별에 따 라서 남자 아이들의 경우 주요 우울증과 사회공포증이 있는 경 우, 여자 아이의 경우 외상 후 스트레스 장애가 있는 경우로 밝 혀졌다. ${ }^{172)} \mathrm{ADHD}$ 가 있는 경우 우울증상 등에 대해서 조기에 적극적인 치료를 실시할 경우 이후 발생할 수 있는 자살의 위 험성을 낮출 수 있으며, 우울장애, 품행장애 그리고 물질 남 용과 같은 공존 질환에 대해서 발견하여 치료를 하는 것이 반 드시 필요하다.

\section{양극성 장애}

양극성 장애와 $\mathrm{ADHD}$ 의 증상은 과도한 짜증스러움, 증가 된 언어 및 활동, 억제의 상실 등 비슷한 점이 많다. ${ }^{173)}$ 양극성 
장애 진단을 받은 아동의 절반 이상에서 $\mathrm{ADHD}$ 의 진단기준을 만족시키며, 이러한 경향은 성인에서도 마찬가지로 양극성 장 애 중 $21 \%$ 에서 $\mathrm{ADHD}$ 를 진단할 수 있다. ${ }^{172)}$ 양극성 장애가 동 반된 경우 조증 삽화에 비해서 우울/혼재성 삽화가 더욱 많이 관찰되며, 이른 발병, 잦은 기분삽화, 다른 정신과적 질환(우 울증, 정신증, 불안장애, 품행장애, 적대적 반항장애), 그리고 기능 손상으로 인한 삶의 질 저하 등과도 연관된다. ${ }^{174)}$ 또한 양 극성 장애가 동반될 경우 그렇지 않은 경우에 비해서 더 심각 한 경과와 잦은 기분삽화를 보이며, 다른 정신과 질환 등의 공 존 장애가 잘 동반된다. ${ }^{175)}$ 특히 조증이 동반될 경우 그렇지 않 은 경우에 비해서 주요 우울증상, 정신병적 증상, 다양한 불안 증상, 품행장애/적대적 반항장애 등이 동반될 가능성이 높으 며 심리사회적 기능의 심한 손상을 보이는 것으로 나타났다.

원인론적 측면에서 $\mathrm{ADHD}$ 와 양극성 장애가 동반될 경우 두 질환 모두 전전두엽의 이상이 발견된다는 의견도 있지만 일반적으로는 서로 다른 특성을 가지는 것으로 생각된다. 신경 심리학적 소견에 따르면 간섭조절, 실행 기억, 인지적 유연성 등과 관련된 부위에서의 차이는 이를 뒷받침하는 결과이다. ${ }^{176)}$

\section{불안장애}

$\mathrm{ADHD}$ 에서 불안장애가 공존하는 비율은 연구에 따라 다 르지만 약 20 40\% 정도이며, 일반 인구에 비해서 3배가량 높 다. ${ }^{118,177)}$ 흔히 동반되는 불안장애는 사회공포증과 분리 불안 장애이며, 우리나라의 경우 분리 불안장애가 가장 높은 비중 을 차지했다. ${ }^{178,179)} \mathrm{ADHD}$ 와 불안장애가 동반되는 경우 각각 이 있는 경우에 비해서 더 심한 주의력 문제, 학교 공포증, 기분 장애, 그리고 낮은 수준의 사회적 적응 등을 보였다. $\mathrm{ADHD}$ 와 불안장애의 유전성 및 공존성에 대한 연구는 대부분 가족연 관분석(familial association studies)에 의해서 이루어졌으며, 그 결과 $\mathrm{ADHD}$ 와 불안장애는 가족 내에서 각각 독립적으로 유전되는 경향을 보이는 것으로 조사되었다. ${ }^{180)}$

불안장애가 동반되는 경우에 충동성이 줄어들고 주의 산만 한 것처럼 보일 수 있기 때문에 $\mathrm{ADHD}$ 가 간과되는 경우가 많 아 주의 깊은 평가가 필요하며, 불안 증상과 더불어 $\mathrm{ADHD}$ 로 인한 증상으로 인해서 더 많은 어려움을 경험할 수 있으므로 적극적인 치료가 필요하다. ${ }^{181)}$

\section{학습장애}

$\mathrm{ADHD}$ 아동에서 정상 대조군에 비해 더 많은 학습장애를 보인다는 것은 밝혀졌지만, 학습장애의 동반율은 다양한 조 건의 연구집단, 평가도구 등에 의해 연구에 따라 $11 \sim 30 \%$ 로 큰 차이를 보인다. ${ }^{138,182)}$ 두 질환이 동반되는 경우 각각의 질환에 의한 문제와 더불어 증상들의 상호작용으로 인해서 심각한
학업문제, 주의력상의 문제, 행동상의 문제가 심해지는 경향 을 보여 학교생활에 어려움을 보인다. ${ }^{174,183)} \mathrm{ADHD}$ 와 난독증 이 공존하는 경우에는 전형적인 난독증만 있는 경우에 비해서 실행기능과 같은 전반적인 인지적 기능 저하 등을 동반하는 경 우가 많다. 또한 이러한 경우에는 2차적으로 문제행동, 저하 된 자존감, 학교 성적 저하 등이 각각의 질병 중 하나만 있는 경 우에 비해서 두드러지게 나타날 수 있다. 그러므로 ADHD 아 동을 평가할 때 주의력검사와 더불어 발달력, 가족력, 학업수 행을 평가하면서 공존하는 학습장애가 있는지를 면밀히 관찰 하여야 한다.

\section{틱장애/뚜렛장애}

뚜렛장애를 포함한 틱장애는 $\mathrm{ADHD}$ 와 동반되는 경우가 흔 하며 약 55 70\%에서 동반되는 것으로 조사되었다. ${ }^{141)}$ 대개 $\mathrm{ADHD}$ 증상은 틱증상이 나타나기 2 3년 전 시작되며, 틱장애 의 가족력이 있는 경우, 증상이 일찍 시작된 경우, 증상이 심각 한 경우에 $\mathrm{ADHD}$ 와의 공존율이 높은 것으로 알려져 있다. 틱 장애가 동반되는 경우 그렇지 않은 경우에 비해서 더 많은 정 신병리, 외재화/내재화 증상과 더불어 낮은 사회적 적응을 보 인다. ${ }^{173,184,185)}$ 틱 증상의 절정은 $\mathrm{ADHD}$ 에 의해서 영향을 받지 않으나 주의력 문제는 틱장애의 심각도와 연관성을 보이고 틱 증상을 억제할 수 있는 능력이 있는 경우 감소된다. ${ }^{186)}$ 이러 한 결과는 $\mathrm{ADHD}$ 환자에 있어서 틱 증상이 심각도와 복잡성 이 $\mathrm{ADHD}$ 증상의 임상적 지표 역할을 할 수 있음을 의미하는 결과이다.

\section{물질 남용}

적절하게 처방된 정신자극제 약물의 경우 물질 남용의 위 험성을 증가시키지 않으며 오히려 후에 발생할 수 있는 물질 남용의 위험을 감소시킬 수 있다고 알려져 있다. ${ }^{187,188)}$ 하지만 전체적으로 $\mathrm{ADHD}$ 가 있을 경우 일반 인구에 비해서 청소년 이나 성인기의 물질 남용의 위험성을 증가시키고 특히 적대적 반항장애나 품행장애가 동반되는 경우에 더욱 위험성이 증가 된다. ${ }^{173,189)}$ 과거에는 이러한 경향이 남자에서 더 두드러진다고 보고되어 왔으나 최근의 연구에 따르면 성별에 따른 차이를 보이지 않는 것으로 조사되었다. ${ }^{134,190)}$ 담배의 사용에 있어서도 $\mathrm{ADHD}$ 가 있을 경우 좀 더 이른 시기에 사용을 시작하며 더 많 은 비율에서 관찰된다. ${ }^{191)}$ 원인론적으로 살펴보면 $\mathrm{ADHD}$ 와 물질 남용 두 질환 모두 도파민 시스템의 이상으로 인한 행동 반응 조절과 동기 조절 시스템의 이상이 관여한다고 생각된 다. ${ }^{192,193)}$ 이는 두 질환 모두에서 관찰되는 dopaminergic gene 의 이상으로 확인할 수 있다. 최근 들어서 주목받고 있는 인터 넷 중독 또한 $\mathrm{ADHD}$ 와 연관성을 보이는 것으로 조사된다. 국 
내연구에 의하면 초등학생에서 $\mathrm{ADHD}$ 를 진단받은 경우 그렇 지 않은 경우에 비해서 인터넷 중독을 동시에 진단받을 가능 성이 높았으며, 이러한 경향은 성인에서도 마찬가지로 관찰되 었다. ${ }^{194,195)}$

\section{성격장애}

$\mathrm{ADHD}$ 를 진단받은 이후 후기 사춘기와 성인기에 진입하게 되면 일부 환자에 있어서는 하나 이상의 성격장애를 진단받 는 경우가 생긴다. 하지만 18세 이전에서는 성인에서 주로 진 단되어지는 반사회적 성격장애 진단보다는 품행장애로 진단 되어지는 경우가 많다. 성격장애로 진단되어지는 경우 보통 중 요한 사회적 기능저하와 관련되는 경우가 많으며, 주로 내려지 는 성격장애는 경계성 성격장애, 반사회적 성격장애, 회피성 성 격장애, 자기애적 성격장애 등이 있다. $\left.{ }^{196}\right)$ 반사회적 인격장애의 경우 $\mathrm{ADHD}$ 를 진단받은 경우 그렇지 않은 경우에 비해서 10배 가량 많은 것으로 조사되었다. ${ }^{116)}$ 성인 $\mathrm{ADHD}$ 와 경계성 인격 장애는 충동성, 감정 조절의 어려움 그리고 인지적 장애 등의 공통된 특성을 보이며, 물질 남용, 저하된 자존감, 대인관계의 어려움 등이 동시에 관찰된다. Fossati 등 197$)$ 은 경계성 성격장 애가 발병하는 데 있어서 아동기의 $\mathrm{ADHD}$ 의 진단이 위험인자 로 작용할 수 있다고 발표하였으며, 이후 시행된 신경심리검사 와 약물 연구에서는 두 질환이 서로 다른 현상이 아니라 한 가 지 질환에서 나온 아형일 수 있다는 가설도 제시되고 있다. ${ }^{198)}$

\section{Non-psychological problems}

앞서 살펴본 정신과적 어려움뿐만 아니라 $\mathrm{ADHD}$ 아동의 경 우 다양한 비정신과적 어려움을 보이는 경우가 많다. 흔히 정 신자극제의 사용이 식욕 및 체중의 감소를 일으킨다고 알려 져 있으며, $\mathrm{ADHD}$ 자체가 출생 시 저체중과 연관된다고 알려 져 있으나 놀랍게도 몇몇 연구에서는 유년기뿐만 아니라 성인 기에 이르기까지 체질량 지수가 증가되었다는 연구 결과가 제 시되고 있다. 아직 확실히 밝혀진 원인은 없지만 가능성이 있 는 요인으로는 $\mathrm{ADHD}$ 자체의 증상인 증가된 충동성, 행동 조 절의 어려움, 정서 조절의 어려움 등이 식이에 영향을 주는 것 으로 생각되고 있다. ${ }^{199)}$ 그 외에도 $\mathrm{ADHD}$ 가 있을 경우 불면, 반 복적 두통, 근육통, 복통 등의 신체 증상을 보이는 경우가 많 으며, 천식, 습진, 감염 등의 질환과 연관성이 있다. 특히 $\mathrm{ADHD}$ 아동의 경우 경련, 배뇨 장애, 수면 장애, 알러지 등을 가지고 있는 경우가 많고, 여자 성인의 경우 섬유근육통이 동반되는 경우가 많다. ${ }^{121-123,135)}$

\section{약물치료}

주의력결핍 과잉행동장애(attention-deficit hyperactivity disorder)의 치료는 크게 약물치료와 행동치료로 구분할 수 있 다. $\mathrm{ADHD}$ 에 대한 병태생리학적 정보가 밝혀지기 전에는 단 지 부모의 잘못된 양육이 자녀의 $\mathrm{ADHD}$ 증상을 만든다는 이 론으로 행동치료적인 접근이 주를 이루었다. ${ }^{72)}$ 하지만 이후 $\mathrm{ADHD}$ 의 신경화학적 이상 소견이 보고되었고 이를 조절할 수 있는 약물이 개발되기 시작하면서 많은 임상가들은 약물 치료에 더욱 집중하기 시작했다. 이러한 쟁점을 정리하기 위하여 Multimodal Treatment Study of Children with ADHD(MTA) 연구가 진행되었고 많은 연구 결과들이 보고되었다. ${ }^{200)}$ 결론적 으로 약물치료 단독이 행동치료보다 $\mathrm{ADHD}$ 증상호전에 있어 우월한 효과를 보였고, 장기간 효과 역시 더 좋은 결과를 보였 다. 더불어 행동치료와 약물치료 두 가지 치료를 병합하는 것 도 약물치료 단독 치료보다 부가적인 이득이 크지 않은 것으 로 알려졌다. ${ }^{201)}$ 하지만 약물치료에 거부감이 심하거나 아이의 상태가 약물치료에 적합하지 않은 경우에는 행동치료가 필요 하므로 적절한 조합이 필요할 것이다.

현재 ADHD 치료제로 식약처(Food and Drug Administration, $\mathrm{FDA}$ )의 승인을 받은 약물은 정신자극제 중 $\mathrm{MPH}$ 가 대 표적인 약물이고, 비정신자극제 중에는 atomoxetine과 $\alpha-$ agonist 계열 약물인 clonidine이 사용 가능한 약물이다. 그 외 삼환계 항우울제(tricyclic antidepressants, TCAs)와 bupropion이 ADHD 증상을 호전시키는 것으로 알려졌지만 FDA 의 승인을 받지 못해 off-label로만 사용이 가능하다. 약물치 료가 결정되면 환자와 보호자에게 약물의 효과와 한계, 그리 고 부작용에 대한 정보를 충분히 제공해야 한다. 약물에 관 한 자세한 정보는 아래에 기술하였다.

\section{정신자극제(Stimulants)}

정신자극제는 많은 연구에서 $\mathrm{ADHD}$ 치료에 효과적인 것 으로 밝혀졌다. 정신자극제의 사용량은 꾸준히 증가하고 있 는 추세이다. ${ }^{202)}$ 미국 소아과학회(American Academy of Pediatrics)와 미국 소아청소년정신과학회(American Academy of Child and Adolescent Psychiatry)에서는 ADHD 치료에 서 정신자극제 사용을 추천하고 있으며, 우선적으로 선택해 야 할 약물로 $\mathrm{MPH}$ 와 amphetamine을 지정하고 있다. 다른 계열의 약물과 비교한 정신자극제의 효과크기(effect size)는 Table 5에 정리하였다. ${ }^{203)} \mathrm{ADHD}$ 를 대상으로 다유형 치료 연 구(multimodal treatment trial)에서는 정신자극제의 사용이 부주의, 과잉행동, 충동성을 호전시킬 뿐 아니라 파괴적 행동 을 약화시키고 학업적 성취와 적절한 교우관계 유지에도 도 
Table 5. ADHD medication effect size ${ }^{204)}$

\begin{tabular}{lc}
\hline & Effect size \\
\hline Stimulant medications & $1.0^{*}$ \\
a-agonist medications, ER & 0.7 \\
Atomoxetine & 0.7
\end{tabular}

0.2: small effect size, 0.5: moderate effect size, 0.8: large effect size. ${ }^{*} 0.4-0.8$ in preschoolers. ADHD: attention-deficit hyperactivity disorder, ER: extended release

움이 된다고 보고하였다. ${ }^{200)}$ 미국에서는 amphetamine 제제 도 널리 사용되고 있으나, 현재 국내에서 $\mathrm{MPH}$ 제제들만 사용 가능하다.

정신자극제의 용량과 임상 반응과는 1차 선형(linear relationship)의 관계로 고용량을 사용할수록 증상은 좋아질 수 있지만 부작용의 위험 역시 증가하게 된다. 따라서 초기 용량 은 가장 낮은 용량으로 시작하여 부작용의 발생 여부를 확인 하고 이후 1 주 간격으로 신속하게 증량할 수 있다. 물론 각 환 자에 따라 반응이 달라질 수 있으므로 환자의 특성에 따른 개 별적인 적용이 필요하다. $\mathrm{ADHD}$ 증상이 충분히 호전되었거 나, 심한 부작용이 나타났을 경우 증량을 중단하며, 그 외에 는 최대 용량까지 증량할 수 있다. ${ }^{205)}$ 최대 용량은 immediaterelease(IR)-MPH와 metadate의 경우 $60 \mathrm{mg}$ /day이고, Concerta의 경우 $72 \mathrm{mg} / \mathrm{day}$ 로 정해져 있지만 체중에 따라 더 높 은 용량이 필요할 수 있다. ${ }^{206)}$ 약물 복용 횟수를 줄여 편의성 을 향상시키기 위해 short-acting stimulant보다 long-acting stimulant를 사용하는 경우가 증가하고 있다. 아침 약물은 소 화불량, 오심 등의 소화기계 부작용을 줄이기 위해 식사 후 복용하는 것이 권장된다. 비록 long-acting stimulant가 12시 간까지 약물효과가 유지된다고 하지만 몇몇 아이들은 약물대 사 속도가 빨라 효과가 유지되지 못하는 경우가 있다. 이러한 경우 오후에 short-acting stimulant를 사용하는 것이 도움이 된다. Texas Children's Medication Algorithm Project에 의 하면 정신자극제를 충분한 기간 동안 최대용량을 사용하였어 도 효과가 부족한 경우 등가용량의 다른 계열 정신자극제를 사용하라고 하였으나, 우리나라의 경우 amphetamine이 시판 되지 않으므로 적용하기 어렵다. ${ }^{201)}$ 대신 $\mathrm{ADHD}$ 로 의심되었 던 과거력 등을 다시 확인하여 초기에 발견하지 못했던 공존 질환(기분, 불안, 발달 장애 등)에 관한 평가가 다시 필요할 것 이다. ${ }^{207)}$ 현재 사용이 가능한 $\mathrm{ADHD}$ 약물의 종류와 권장 용 량, 주의해야 하는 부작용에 관해서 Table 6에 정리하였다.

\section{Immediate-release(IR)-methylphenidate}

Methylphenidate가 $\mathrm{ADHD}$ 치료에 효과적이라는 사실은 이미 50년 전부터 보고되었다. 하지만 작용시간이 짧다는 특 징 때문에 최소한 하루에 2 번 이상 복용하는 번거로움이 있
었다. 이후 개발된 sustained-release(SR) MPH가 이러한 단 점을 극복하여 8시간 이상의 작용시간을 보여주고 있지만, IR-MPH에 비해 작용개시 시간(onset of action)이 느린 특성 을 가지고 있으므로 두 가지 제형의 상호보완적 활용이 가능 하다. ${ }^{208)}$

\section{Long-acting form methylphenidate}

IR-MPH의 단점을 보완하기 위해서 $\mathrm{MPH}-\mathrm{SR}$ (ritalin SR) 가 개발되었다. 약물의 효과가 8시간 정도 유지되어 아침에 복용한 뒤 학교에서는 약물을 복용하지 않아도 되어 환자와 부모 모두 만족도가 향상되었고 따라서 순응도 역시 좋아졌 다. 초기 투여 시 short-acting form으로 증량하고 long-acting form으로 넘어갈 필요 없이 바로 long-acting form으로 사용 한다. 비록 IR-MPH 제제보다 작용시간은 증가했지만 작용개 시 시점이 늦어지고 효과적인 면에서 부족하다는 의견도 있 었다. ${ }^{208)}$ 현재 우리나라에서 사용 가능한 long-acting form은 아래와 같다.

\section{Concerta ${ }^{\circledR}$ (OROS-methylphenidate)}

Concerta $^{\circledR}$ 는 약물효과가 나타나려면 1시간 정도 소요되고 대략 12.5 시간의 작용시간을 가지는 것으로 보고되었으며 ${ }^{209)}$ 2000년에 처음 FDA 승인을 받았다. ${ }^{210)}$ Concerta ${ }^{\circledR}$ 겉에 IR$\mathrm{MPH}$ 가 둘러싸고 있고, 안으로는 반투막(semipermeable)과 두 개의 IR-MPH 층과 삼투압으로 활성화되는 한 개의 층으 로 이루어진 핵심부분(core)으로 구성되어 있다. 물이 작은 구 멍을 통해 tablet 안으로 들어가면 안에 있던 IR-MPH를 밖 으로 밀어내게 되고 6 7시간 동안 그 양이 증가하는 양상을 보 인다. ${ }^{211)}$ 즉, Concerta $^{\circledR} 18 \mathrm{mg}$ 을 복용한 경우 처음 $4 \mathrm{mg}$ bolus 가 방출되고 이후, 하루 3번 IR-MPH $5 \mathrm{mg}$ 용량이 ascending profile로 전달되어 방출하게 된다. ${ }^{212)}$ 이러한 장기적인 지속효 과를 얻기 위해서는 $\mathrm{OROS}$ 제제를 분할하지 않고 그대로 복 용하는 것이 중요하다. 한 개방형 연구에서는 OROS-MPH가 IR-MPH에 비해 ADHD 치료에 더 좋은 효과를 보이는 것으 로 나타났는데, 이러한 결과의 가장 큰 이유로는 하루에 한 번만 복용해도 된다는 점 때문에 순응도가 향상되었기 때문 이었다. ${ }^{213)}$

\section{Metadate $^{\circledR}$}

Metadate $^{\circledR}$ 는 미국에서 처음 $\mathrm{ADHD}$ 치료제로 승인을 받았 다. 두 가지 구성성분인 IR-MPH와 extended-release(ER) $\mathrm{MPH}$ 가 30:70 비율로 섞여 있다. 유럽에서는 equasym XL이 라는 이름으로 판매되고 있다. ${ }^{214)}$ 이 약물 역시 통째로 삼켜서 복용하는 것을 권장하고 있으나 캡슐을 열고 안에 내용물을 
주스 같은 음식물에 뿌려서 복용하는 방법도 FDA에서 인정 받고 있다. 복용한 뒤 1.5 시간 후에 첫 번째 최고 농도에 도달 하고 4.5시간 후에 두 번째 최고 농도에 도달하며, 효과는 12 시간까지 지속된다고 알려졌다. 두 번째 최고 농도를 보이며 효과는 12 시간까지도 지속된다고 알려졌다. ${ }^{215)}$ 이와 비슷한 구 성성분인 약물로 ritalin LA가 있고, IR과 ER의 비율이 50:50인
점이 차이점이다. ${ }^{216)}$ 하지만 현재 국내에서는 시판되지 않아 사 용할 수 없다.

\section{특수한 대상에서의 적용(학령 전 아동)}

많은 어린 아이들, 특히 학교를 들어가기 전의 만 4 5세 아이 들도 $\mathrm{ADHD}$ 진단을 받을 수 있으며 정신자극제와 같은 약물

Table 6. Pharmacotherapeutic agent for the treatment of ADHD in children and adolescents

\begin{tabular}{|c|c|c|c|c|c|}
\hline Generic class & Brand name & Dose & $\begin{array}{l}\text { Duration } \\
\text { of effect }\end{array}$ & Common side effects & Uncommon side effects \\
\hline $\begin{array}{l}\text { Methylphenidate } \\
\text { stimulants }\end{array}$ & & & & $\begin{array}{l}\text { Headache, abdominal } \\
\text { pain, decreased } \\
\text { appetite, delayed } \\
\text { onset of sleep }\end{array}$ & $\begin{array}{l}\text { Tics, slowed rate of } \\
\text { growth, agitation or } \\
\text { anxiety, increased } \\
\text { heart rate or blood } \\
\text { pressure }\end{array}$ \\
\hline Methylphenidate IR & $\begin{array}{l}\text { Penid 5, } 10 \text { mg, } \\
\text { Perospin Tab } \\
10 \mathrm{mg}\end{array}$ & $\begin{array}{l}5 \text { mg two or three } \\
\text { times a day, to a } \\
\text { maximum of } 60 \mathrm{mg}\end{array}$ & $3-5$ & & \\
\hline Concerta & $\begin{array}{l}\text { Concerta OROS Tab } \\
18,27 \mathrm{mg}\end{array}$ & $\begin{array}{l}18 \text { mg/day, to a } \\
\text { maximum of } 72 \mathrm{mg}\end{array}$ & 12 & & \\
\hline Metadate CD & $\begin{array}{l}\text { Metadate CD ER } \\
\text { cap 10, 20, } 30 \mathrm{mg} \\
\text { Medikinet retard } \\
\text { cap } 10,20,30,40 \mathrm{mg}\end{array}$ & $\begin{array}{l}20 \mathrm{mg} / \mathrm{day} \text {, to a } \\
\text { maximum of } 60 \mathrm{mg}\end{array}$ & $6-8$ & & \\
\hline $\begin{array}{l}\text { Norepinephrine- } \\
\text { reuptake inhibitor } \\
\text { (atomoxetine) }\end{array}$ & & & & $\begin{array}{l}\text { Upset stomach, } \\
\text { decreased appetite, } \\
\text { dizziness, fatigue, } \\
\text { nausea, mood swings }\end{array}$ & $\begin{array}{l}\text { Jaundice and liver } \\
\text { involvement, suicidal } \\
\text { ideation, slowed rate } \\
\text { of growth, allergic } \\
\text { reactions, priapism }\end{array}$ \\
\hline Strattera & $\begin{array}{l}\text { Strattera Cap 10, 18, } \\
\text { 25, 40, 60, } 80 \text { mg } \\
\text { Atomoxin Cap 10, } \\
\text { 18, } 25 \mathrm{mg} \\
\text { Atocera Cap 10, 18, } \\
\text { 25, } 40 \mathrm{mg} \\
\text { Artlex Cap 18, 25, } \\
\text { 40, } 60 \mathrm{mg} \\
\text { Whanin atomoxetine } \\
\text { Cap 18, 25, 40, 60, } \\
80 \mathrm{mg}\end{array}$ & $\begin{array}{l}0.5 \mathrm{mg} / \mathrm{kg} / \text { day once } \\
\text { or twice daily, } \\
\text { to a maximum } \\
\text { of } 1.4 \mathrm{mg} / \mathrm{kg}\end{array}$ & $\begin{array}{l}\text { At least } \\
10-12\end{array}$ & & \\
\hline $\begin{array}{l}\text { a2-adrenergic } \\
\text { agonists }\end{array}$ & & & & $\begin{array}{l}\text { Somnolence and } \\
\text { sedation, fatigue, } \\
\text { insomnia, nightmares, } \\
\text { dizziness, dry mouth, } \\
\text { symptoms of upper } \\
\text { respiratory tract } \\
\text { infection }\end{array}$ & $\begin{array}{l}\text { Cardiac conduction } \\
\text { abnormalities, mood } \\
\text { changes, allergic } \\
\text { reaction }\end{array}$ \\
\hline $\begin{array}{l}\text { Extended-release } \\
\text { clonidine }\end{array}$ & $\begin{array}{l}\text { Kapvay ER tab } \\
0.1 \mathrm{mg}\end{array}$ & $\begin{array}{l}0.1 \mathrm{mg} \text { once or twice } \\
\text { daily, to a maximum } \\
\text { of } 0.4 \mathrm{mg} / \text { day }\end{array}$ & $\begin{array}{l}\text { At least } \\
10-12\end{array}$ & & \\
\hline
\end{tabular}

ADHD: attention-deficit hyperactivity disorder, ER: extended release, IR: immediate-release 
치료로 호전을 기대할 수 있다. 하지만 실제로 이 연령을 대상 으로 하는 약물치료는 많이 진행되고 있지 않다. 미국 National Institutes of Mental Health(NIMH)에서 진행한 PATS 연구 결과에서도 IR-MPH는 학령전기 아동에게도 효과적이지만 학령기 아동에 비해 effect size는 적은 것으로 보고되었다. ${ }^{217)}$ 그 외에도 학령 전 아동을 대상으로 행동치료 단독으로도 충 분한 임상적 호전을 보였다는 점과 여전히 남아있는 성장지연 에 대한 부모들의 걱정이 크다는 점 때문에 약물치료가 제한 적으로 사용되고 있다. ${ }^{218)}$ 만 4 5세의 아동을 대상으로 하는 연구는 그리 많지 않다. 주로 MPH 관련 연구였고, 한 개의 다 기관 연구와 10 개의 다소 규모가 작은 단독기관 연구가 보고 되었다. ${ }^{218)}$ 이를 통해 보고된 ADHD 아동의 총 수는 269 명이 었고, 10 개의 단독기관 연구 중 7 개의 연구가 유의한 효과가 있다고 보고하였다. 효과뿐 아니라 안정성 측면에서도 크게 우려할 점은 보고되지 않았지만 아직 FDA 승인을 받지 못했 으므로 off-label로 사용되고 있는 실정이다. 만 4 5세의 아 동은 정신자극제 대사가 느리다는 연구 결과가 있으므로 초 기 용량을 더 줄이고 증량 역시 더 작은 단위로 시행하는 것 이 안전하다. ${ }^{218)}$

\section{청소년과 성인 $\mathrm{ADHD}$}

최근 발표된 장기간 추적 연구에 따르면, 아동기에 $\mathrm{ADHD}$ 로 진단된 환자의 30 70\%가 청소년을 거쳐 성인이 되어서도 진단기준을 만족하며 유병률은 1 6\%로 보고하고 있다. ${ }^{45}$ 따 라서 청소년과 성인 $\mathrm{ADHD}$ 를 대상으로 하는 치료의 필요성 이 대두되었다. 최근 연구 결과에 따르면 청소년기에도 어린 아동의 경우와 마찬가지로 정신자극제의 효과가 있다고 보고 하고 있으며 이는 성인에서도 마찬가지 결과였다. ${ }^{219}$ 하지만 약 물 사용 시 주의할 점으로 물질 남용의 위험성을 평가하는 것 이다. 실제로 청소년들 사이에서 $\mathrm{ADHD}$ 약물을 치료 이외 다 른 목적으로 사용하는 경우가 많이 발생하였고, 이에 대한 임 상가의 주의가 필요하다. ${ }^{220)}$ 중독의 위험성이 있는 청소년들은 중독 가능성이 떨어지는 약물인 atomoxetine 또는 ER clonidine을 사용하는 것이 안전하다. ${ }^{220}$

\section{비정신자극제(Nonstimulant)}

$\mathrm{MPH}$ 혹은 amphetamine 계열의 정신자극제가 $\mathrm{ADHD}$ 치 료의 첫 번째 선택약물로 되어 있고 효과성 역시 많은 연구에 서 입증이 되어 있다. 하지만 여러 가지 이유로 비정신자극제 약물치료가 사용되고 있으며 6세 이상의 아동을 대상으로 $\mathrm{FDA}$ 승인을 받았다. 비정신자극제를 선택하는 이유를 살펴 보면, 정신자극제를 최대한 사용했지만 충분한 반응을 보이 지 않았던 경우, 정신자극제에 심한 부작용이 발생한 경우, 식
욕부진으로 인한 성장지연에 대한 걱정이 많은 부모인 경우, 아동이 저체중인 경우, 환아 또는 가족구성원에서 중독의 위 험성이 의심되는 경우에 atomoxetine 혹은 $\alpha$-agonist와 같은 비정신자극제를 선택하게 된다. 이들 약물은 단독 치료로도 효과가 있지만 정신자극제에 치료반응이 부분적인 경우 병합 치료로써도 도움을 줄 수 있다.

\section{Atomoxetine}

Atomoxetine은 선택적 노르에피네프린 재흡수 억제제로 많은 연구를 통해 효과가 입증이 되어 만 6세 이상의 아동과 청소년을 대상으로의 사용에 FDA 승인을 받았다. ${ }^{221)}$ 기존의 연구들을 통해 atomoxetine은 아동, 청소년, 성인 $\mathrm{ADHD}$ 환자 들에서 위약보다 좋은 효과를 보이는 것으로 밝혀졌고, ${ }^{222}$ 효 과와 안정성에 관한 메타분석 연구에서도 두 가지 모두 위약 에 비해 유의하게 좋은 것으로 입증되었다. ${ }^{223)}$ 그 외 공격성에 서는 큰 차이를 보이지 않았지만 자살사고와 행동에 있어 유 의한 차이를 보였다는 연구 결과도 보고되었다. ${ }^{224)}$ 다른 $\mathrm{ADHD}$ 약물들과 마찬가지로 반항적인 모습에도 효과적인 것 으로 밝혀졌고, ${ }^{225)}$ 특히 불안장애가 공존하는 경우 다른 약물 들에 비해 우월한 결과를 나타냈다. 226 최근 총 3928 명의 $\mathrm{ADHD}$ 아동을 대상으로 하는 대규모의 메타분석 연구에서 는 atomoxetine의 치료 효과가 비록 stimulants와 $\alpha$-agonist인 guanfacine ER보다 효과가 부족한 것으로 나타났지만, 긍정 적인 효과는 분명히 있는 것으로 입증되었기 때문에, 앞서 이 야기한 적응증과 부작용 측면을 모두 고려하여 약물을 선택 하는 것이 합리적일 것이다. ${ }^{227}$

Atomoxetine 증량은 최소한 3일 간격으로 목표 용량까지 도달하는 것을 권장하고 있고, 하루에 두 번을 나누어 복용 하는 경우 반항적인 양상과 소화기계 부작용을 줄일 수 있는 것으로 알려졌다. ${ }^{228)}$ Fluoxetine과 같이 CYP2D6 억제효과가 있는 약물을 같이 복용하는 경우 더 적은 용량으로 천천히 증량하는 것이 필요하다. 정신자극제에 비해 수면과 식욕에 미 치는 영향은 상대적으로 적으나 오심과 진정은 더 많이 발생 할 수 있다. ${ }^{229)}$ Atomoxetine은 치료 시작 1주부터 위약보다 효과가 좋았고, 6 주경에 최대효과가 관찰될 수 있다. 하지만 평균적으로 stimulant와 $\alpha$-agonist 약물에 비해 천천히 약물 효과가 나는 것으로 밝혀졌다. 따라서 환자 및 부모에게 최소 한 2 6주간 지속 투여하면서 효과 여부를 판정하는 것이 중 요함을 설명해야 한다. ${ }^{203)}$

\section{$\alpha$-agonist(Clonidine and guanfacine)}

앞서 언급했듯이 stimulant를 사용하기 어려운 경우 다른 대체 약물을 찾아야 하는데 그중 $\alpha$-agonist 계열의 약물로 
clonidine과 guanfacine이 있다. 본래 항고혈압 약제로 개발 되었고 뇌간에 위치한 수용체를 자극함으로써 말초신경의 sympatho-inhibition을 유발시켜 혈압을 낮추는 작용을 하 였다. ${ }^{230)}$ 고혈압 약물로 널리 사용되던 중 $\mathrm{ADHD}$ 를 비롯한 여 러 정신과적 증상 치료에 도움이 된다는 연구 결과들이 발표되 면서 오랜 시간 off-label로 사용되어 왔다. ${ }^{231}$ 특히 stimulant 와 atomoxetine으로 치료 받는 과정에서 문제행동, 틱, 수면 장 애 등이 지속되는 경우 이 계열의 약물을 사용하는 경우 효과 적인 것으로 보고되었다. ${ }^{232)}$

Clonidine은 단독 혹은 stimulant와의 병합요법으로 ADHD 증상을 감소시키지만, 전반적인 효과크기는 앞서 설명한대로 stimulant보다 적다. ${ }^{219)}$ 더욱이 약물 기전상 발생할 가능성이 높은 진정효과, 서맥, 저혈압 등의 부작용 때문에 사용이 제한 되었었다. ${ }^{233}$ 하지만 최근 발표된 메타분석 연구 결과처럼 효과 성과 안정성 모두 확보되어 있어 미국에서는 만 6 17세 이하 의 $\mathrm{ADHD}$ 소아청소년 환자에 있어서 단독요법 또는 다른 stimulant와의 병용용법이 FDA 승인은 받은 상태이다. ${ }^{234} 6 ~ 17$ 세의 $\mathrm{ADHD}$ 소아청소년 환자를 대상으로 2개의 무작위, 이중 맹검, 3상 연구에서 단독요법과 병용요법 모두 $\mathrm{ADHD}$ 증상 감소에 효과적이었고, clonidine $0.2 \mathrm{mg}$ 의 효과크기는 0.713 , $0.4 \mathrm{mg}$ 의 효과크기는 0.766 이었다. ${ }^{235,236)}$ 가장 흔한 부작용은 졸림과 피곤이었지만 clonidine의 복용량과는 무관한 것으로 나타났고, 237$)$ 치료 중 발생한 심혈관계 이상은 약물에 의한 것 이 아니며 위험한 상호작용 역시 발견할 수 없었다고 한다. ${ }^{238}$ 한편 guanfacine은 clonidine과 유사하지만 조금 더 선택적인 $\alpha-2$ adrenergic agonist이다. Clonidine은 $\alpha-2 \mathrm{~A}, \alpha-2 \mathrm{~B}, \alpha-2 \mathrm{C}$ adrenoceptor와 비슷한 비율로 결합하는 반면, guanfacine은 전전두엽 부위의 시냅스 후 $\alpha-2 \mathrm{~A}$ adrenoceptor에 더 경쟁적 으로 결합하는 특성을 가졌다. ${ }^{239)}$ 이러한 차이점 때문에 clonidine에 비해 중추신경계를 저하시킴으로 인해 발생하는 진정작용과 혈압을 낮추는 등의 부작용이 적고 비교적 작용 시간이 길다는 장점을 갖는다. ${ }^{240)}$ 여러 연구에서 $\mathrm{ADHD}$ 와 틱 이 동반되어 있는 아동에서 효과적인 것으로 보고되었고, ${ }^{241}$ 2009년 미국 FDA에서 만 6 17세 아동을 대상으로 약물을 사 용하는 것이 승인되었다.

두 약물 모두 혈압을 낮추는 효과가 있으므로 좀더 엄격한 약물처방 및 조절이 필요하다. 과용량을 복용한 경우 저혈압의 위험성이 있으며, 불규칙한 복용은 반응성 고혈압(rebound hypertension)을 발생시킬 수 있다. 진정작용이 있으므로 초 기에는 자기 전에 복용하는 것이 권장되며 clonidine은 아침과 저녁 2회 복용법으로 주마다 서서히 증량하는 것이 원칙이다. 효과는 약물치료 시작 1 3주 사이에 관찰할 수 있으나 최종 효과 판정은 충분한 용량을 6주간 사용한 뒤 하는 것이 좋다.
만약 2일 이상 약물 복용을 중단한 경우에는 다시 초기 용량 부터 시작하는 것이 안전하다. 갑작스런 중단으로 반응성 고혈 압과 틱이 발생할 수 있으므로 1주 간격으로 점진적으로 감량 하는 것이 필요하다. ${ }^{203}$

\section{Bupropion}

Bupropion은 여러 연구를 통해 ADHD 증상을 개선시키며 공존 질환 중 우울장애나 흡연 등의 문제가 있는 경우 효과적인 것으로 보고되고 있다. 현재 국내에는 IR, SR, ER의 3가지 제 형이 시판되어 사용되고 있다. 기존의 여러 연구에서 $\mathrm{ADHD}$ 치료에 있어서도 효과가 입증되었으나 FDA 승인을 받지 못해 여전히 off-label로만 사용이 가능하다. ${ }^{242}$ Bupropion은 다른 비정신자극제인 atomoxetine이나 $\alpha$-agonist 계열의 약물보다 작용개시 시간이 빠르며 효과크기 역시 부족하지 않은 것으 로 알려졌다. 또한 $\mathrm{MPH}$ 가 가지고 있는 남용 및 의존성이 위 험이 거의 없다는 장점을 가진다. 그러나 성인과 마찬가지로 발 작(seizure)과 식이장애(eating disorder)의 위험성이 있는 경우 사용하지 않는 것을 권장한다. ${ }^{72)}$

아동청소년이 bupropion SR을 복용했을 경우 성인에 비해 반감기가 더 짧다는 보고가 있어 하루에 두 번 분복하는 것 이 권장되고, 이를 통해 약물로 인해 발생할 수 있는 부작용을 줄일 수 있다. ${ }^{243}$ 초기 용량은 $3 \mathrm{mg} / \mathrm{kg}(100 \sim 150 \mathrm{mg})$ 으로 시작 하며 $6 \mathrm{mg} / \mathrm{kg}(300 \mathrm{mg})$ 까지 증량할 수 있다. 발작의 위험성이 증가할 수 있으므로 한 번에 IR $150 \mathrm{mg}$, SR $200 \mathrm{mg}$, ER 300 $\mathrm{mg}$ 이상을 복용하지 않도록 한다. ${ }^{23,244)}$ 그 외 신기능과 간기 능에 이상이 있는 아동청소년의 경우에는 더 적은 용량으로 치 료를 시도해야 한다. ${ }^{24,245)}$ 비록 최근 발표된 메타분석 연구에 서 다른 $\mathrm{ADHD}$ 약물치료보다 효과가 부족한 것으로 나타났 지만, 이는 아동청소년에서 bupropion에 관한 무작위 배정, 이 중맹검 약물 연구가 부족한 것이 그 이유로 제시되었다. ${ }^{225,246)}$ 따라서 임상에서는 개인 특성에 따라 사용을 충분히 고려할 수 있는 ADHD 약물치료로 보고되고 있다.

\section{Tricyclic antidepressants}

TCAs 역시 ADHD의 off-label 약물치료로 많이 사용되어 왔다. 작용시간이 긴 특성 때문에 남용의 위험성이 있는 환자 에게 사용하기 용이하고, 우울증이나 틱 관련 문제가 있는 경 우 사용을 고려할 수 있다. ${ }^{226,247)}$ 하지만 약물이 가진 심혈관계 부작용의 위험성으로 우선 선택되는 약물은 아니며 $\mathrm{ADHD}$ 치 료 효과 역시 정신자극제에 비해 부족하다는 것이 입증되어 최근 사용이 많이 감소하였다. TCAs의 종류로는 imipramine, desipramine, nortriptyline이 있는데, 그중 desipramine은 사 용 중 돌연사(sudden death)가 보고되어 최근에는 거의 사용 
하지 않고 있다. ${ }^{70)}$ 심혈관계 이상은 가장 중대한 부작용 중 하 나이므로 TCAs를 사용하기 전과 증량하는 과정에서 항상 점검하여 안전성을 확보해야 한다. ${ }^{227)} \mathrm{TCAs}$ 는 CYP2D6에 의 해 대사되므로 다른 약물과의 상호작용에 주의해야 하며, 대 사작용이 느린 환자(slow metabolizer)는 약물 증량에 있어서 더욱더 주의가 필요하다. ${ }^{28,248)}$ Imipramine을 사용할 경우 6세 이상의 아동은 하루에 $10 \mathrm{mg}$ 으로 시작하도록 한다. 이후 증 량하기 위해서는 6 8세는 $20 \mathrm{mg}$ 씩, 9 14세는 20 50 mg씩, 14세 이상에서는 50 80 mg씩 10일 이상의 간격을 둘 것을 권장하고 있다. ${ }^{229,249)}$

\section{비약물치료}

$\mathrm{ADHD}$ 의 치료에는 다방면적인 접근과 치료 계획이 필요하 다. 약물치료가 1 차 치료로써 효용성이 입증되어 있으나 환자 나 가족이 약물치료를 거부할 수 있으며 불면, 식욕부진, 성 장지체 등의 부작용으로 인해 약물치료를 꺼리는 경우도 있 다. 한 연구에 따르면 $\mathrm{ADHD}$ 로 진단받은 아이들의 $45 \%$ 정도 가 약물치료를 시작하지 않은 것을 알 수 있다. ${ }^{250)}$ 또한 약물 치료를 받는 경우에도 약물치료에 반응하지 않거나 잔존 증 상으로 인해 어려움을 겪을 수 있다. 이를 위해 여러 종류의 비 약물적 치료 방법들이 적용되고 있으며 여러 연구들을 통해 그 유효성이 검증되고 있다. 약물치료를 받는 환자들에서 잔 존 증상을 가지는 경우, 비약물적 치료법은 약물효과와 더불 어 부가적인 치료 효과를 가져오며 ${ }^{251,252)}$ 대다수의 전문가와 치료 가이드라인들은 약물치료에도 불구하고 잔존 증상으로 어려움을 겪는 경우, 그룹 또는 개인으로 질병 중심의 정신치 료를 하는 것을 권고한다. ${ }^{253-255)}$

\section{부모교육}

$\mathrm{ADHD}$ 아동들은 여러 동반된 증상들로 인해 지시 따르기가 되지 않고 일상 생활에서 할 일을 수행하지 못하는 등 문제행 동을 보이는 경우가 많다. 부모들은 이에 대해 부정적으로 반 응하게 되며 부모와 아동의 상호작용이 강압적인 과정이 되 며 서로의 행동을 부정적 강화를 통해 조절하려고 한다. 예를 들어 아동이 부모의 지시를 따르지 않으면 부모는 부정적으로 반응하게 되며 하나의 순환고리를 만들어 매번 감정적 어조 나 그 심각성이 상승하게 된다. 부모나 아동 중 하나가 상대의 요구를 들어주게 되면 순환고리는 끝이 나게 되나 상승하는 부 정적 행동 양식은 강화된다. ${ }^{256)} \mathrm{ADHD}$ 환아들에서 보이는 기 능적 결합과 품행문제들은 이러한 과정을 통해 강화된다.

부모교육 프로그램은 이러한 여러 문제점들을 개선시키기 위한 것으로 $\mathrm{ADHD}$ 의 위험이나 다른 품행적 질환들의 위험
을 가진 아동들의 부모를 대상으로 하게 된다. 여러 부모교육 의 주된 공통점은 긍정적, 지지적이고 세밀한 부모 역할을 증 가시키고 주도적이고 적절한 훈육 전략을 이용하여 양육의 일관성을 높이는 것이다. 부모교육은 $\mathrm{ADHD}$ 의 증상보다는 기능적 결합에 초점을 두고 있다. 아동과 청소년 $\mathrm{ADHD}$ 환아 들에서 정해진 시간에 숙제를 하는 것과 같이 부모의 요구를 잘 따르게 하고 아침에 학교가기 준비 등 일상 생활을 해나갈 때 부모에 의존하는 것을 줄이며 부모들의 요구에 대한 반항 을 줄이는 것 등이다. 또 다른 목표는 부모들의 고압적이고 비 기능적인 부모 역할을 다루는 데 있다. 이러한 고압적인 부모아이의 관계 순환고리는 가정 바깥 환경에서의 여러 가지 기 능적 결합을 예측하게 한다. 품행문제를 가진 아동에서는 부 모의 관리 기술을 향상시킴으로써 문제행동을 줄이는 효과 를 가져올 수 있다. ${ }^{257}$ 이처럼 부모교육은 $\mathrm{ADHD}$ 에 특이적인 치료는 아니지만 파괴적인 행동을 가진 아동들에게 효과적이 다. 특히 아동기 $\mathrm{ADHD}$ 환아들에게 효과적인 치료법이나 ${ }^{258}$ 청소년기에는 아동기에 비해 덜 효과적이다. ${ }^{259}$

부모교육은 주로 주 1 회 세션으로 시행되며 그룹이나 개별 교육으로 진행된다. 방식은 3 가지 기본 타입으로 나눠볼 수 있다.

1) 환경적 사건들의 변화를 통해 아동의 긍정적 행동이나 부 정적 행동의 빈도를 증가, 또는 감소시키는 것(부모 조언, 업무 요구, 교사 설명 등)

2) 주어진 업무를 할 수 있도록 재구성하는 것(업무량 줄이 기, 흥미있는 과제물 추가하기 등)

3) 아동 행동의 결과의 본성을 변화시키는 것(관심, 칭찬, 토 큰 강화, 체벌 등)

예를 들어 구체적인 주제들을 살펴보면 ${ }^{260)}$

1) 긍정적인 부모의 관심과 특별 시간을 제공한다.

2) 사회적이고 감정적인 교감을 하고 지속적으로 지도한다.

3) 효과적인 칭찬과 격려를 사용한다.

4) 동기 부여를 위한 명확한 보상프로그램을 사용한다.

5) 규칙, 책임감, 할 일 등을 효과적으로 실행시키는 방법

6) 배워야 할 일상을 예측 가능하게 해주고 명확한 경계를 설정하여 주는 것.

7) 나쁜 행동은 무시하기

8) 안정시키기 위해 타임아웃 사용

행동부모교육은 강화 기술(긍정적 주의, 칭찬 등)의 수행에 초점을 두고 있는데 그것은 다음과 같은 이유 때문이다.

1) 강화를 사용하는 것은 파괴적인 행동을 적게 야기하며 체벌 기술의 필요성을 줄인다.

2) 강화를 사용함으로써 강제적인 순환이 중단된다.

3) 강화 프로그램을 지속적이고 효과적으로 수행하는 것이 
체벌 프로그램을 꾸준히 수행하는 것보다 하기가 쉽다.

부모교육의 효과에 대한 여러 연구들에서 아동의 파괴적인 행동을 줄이는 데 효과가 있는 것으로 보고되었지만 연구 결 과들의 대부분은 부모 보고에 의존하고 있기 때문에 그 결과 가 다소 긍정적으로 보고되었을 가능성이 있다. 또한 대부분의 연구들이 부모교육 시행 이후 수개월 안의 결과들이어서 장기 적 효과에 대해서는 알 수 없다. ${ }^{261)}$ 그리고 그 효과가 가정 환경 에 국한되어서 평가되었기 때문에 학교 등과 같이 다른 환경 에서까지 일반화시킬 수 없다.

\section{학교에서의 행동적 개입}

교사 교육은 학교 상담 교사나 학생정신건강증진 사업 내 전 문가 교육 등을 통해 이루어질 수 있다. 교육의 내용은 교실 내 에서 사용하는 전략과 아동 개인에 사용되는 내용 모두를 포 함한다. 교사들은 효과적인 주도적 학급 운영 방안을 교육받 는데 지속적인 학급 규칙과 할 일들, 경계를 설정하는 것, 반 학 생 모두를 대상으로 하는 긍정적 강화, 그리고 학급 내에서 파 괴적인 행동들을 보이는 일부 아이들에게 동일한 전략을 개 별적으로 적용시키는 것 등이다.

일반 학급에서 $\mathrm{ADHD}$ 환아들은 주의를 분산시키는 여러 상 황들(창문, 출입문, 장난감 등)로부터 떨어진 곳, 가능한 교사 근처에 자리를 배치한다. 학업수행은 가능한 오전 시간에 하도 록 하며 오후 시간에는 신체 활동 수업을 더 많이 배치한다. 학 업 시 수행 시간이 짧아야 하고 난이도가 환아의 개별 능력 에 맞춰지게 한다. 가능한 쉬운 과제를 통해 자신감을 쌓은 후 어려운 과제를 제시한다. 신체적 활동은 증가시키는 방향으로 여러 심부름을 지시하고 수업을 진행하는 것이 과제를 수행하 는 행동을 개선시킨다. 환아의 상태에 맞는 교사의 유연한 대 처가 필요하다.

$\mathrm{ADHD}$ 환아들이 학급 내에서 긍정적인 행동을 유지하도록 하는 몇 가지 기본적인 전략들이 있다. ${ }^{262}$

1) 학생들에게 학급 규칙에 대해 자주 상기시켜주고 적절한 행동이 나타나면 공개적으로 칭찬해준다.

2) 학생과 적절한 눈맞춤을 유지한다.

3) 새로운 활동을 시작하기에 앞서 학생에게 기대되는 행동 을 상기시킨다.

4) 교실 내에서 돌아다니며 학생을 능동적으로 감시한다.

5) 행동을 수정하기 위해 비언어적 신호를 사용한다.

6) 학급 내 활동들에서 적절한 속도를 유지한다.

7) 활동들의 명확한 일과표를 제시한다.

증상이 심하고 파괴적인 행동이 동반된 $\mathrm{ADHD}$ 환아들에게 는 학급 내에서 어떤 시기에 어떠한 방법으로 적절하게 개입할 지를 지도하는 해석적 아동 평가(comprehensive child assess- ment)에 중심을 둔다. 학교에서의 행동적 개입은 부정적인 행 동의 전후관계(선행요인과 결과)를 이해함으로써 긍정적 행동 의 개선 방법을 모색한다. 부정적 또는 수행 거부적 행동은 다 음과 같은 기능을 한다.

1) 원하지 않는 행동이나 상황을 피하거나 도망가는 것

2) 선호하는 상황이나 물건을 얻기 위해

3) 관심을 얻기 위해

4) 감각 자극

행동적 개입에는 순행적 개입과 반응적 개입이 있다. 순행적 개입은(조언과 단서 사용) 파괴적 행동의 선행요인에 직접적인 것으로 $\mathrm{ADHD}$ 를 가진 환아들이 그러한 행동에 개입이 덜 되도 록 한다. 한편 반응적 개입은 행동의 결과에 초점을 두며 긍정 적인 행동은 강화(토큰 이코노미)하고 부정적인 행동(공격성에 대한 타임 아웃 등)은 무시하거나 체벌한다. 두 가지 방법 모두 를 적절하게 사용하는 것이 더 효과적인 결과들을 가져온다.

행동에 대한 일기(daily report cards, DRC)는 학생들의 행 동에 대해 학교와 가정의 규칙적인 의사소통을 위해 고안된 형태이다. DRC에는 명확하게 명시된 목표 행동 리스트가 있 고 일정 시간 동안(학교 내 활동 시간) 그 행동들이 나타날 경 우, 그것의 빈도, 기간 등을 체크하도록 되어 있다. 이상적으 로 학생이 $\mathrm{DRC}$ 를 부모에게 보여주면 목표치가 달성했을 경 우, 부모는 미리 정해진 보상을 해주게 된다. 부모의 협조가 어려운 경우, 교사는 강화방법으로써 토큰 강화 시스템을 사 용할 수 있다. 학교에서의 행동적 개입은 여러 연구가 이루어 졌으며 아동들의 문제행동을 줄이는데 효과적이며 그들의 초 기 학업 능력을 향상시키는 데도 도움이 된다. ${ }^{263,264)}$

\section{방학 훈련 프로그램}

방학 훈련 프로그램은 효과가 증명된 여러 가지 중재 프로 그램들의 집합체로 아동을 캠프와 같은 환경에 초대하는 것 이다. 대부분 이러한 개입들은 아동들의 자연적 환경에서 조 작적 조건화와 사회적 학습 원리에 의존하여 이루어진다. 이 프로그램은 5가지 요소들을 포함한다.

1) 아동 행동 관리를 위한 부모 훈련

2) 행동변화기술의 학급 내 수행

3) 학업적 그리고 스포츠 기술의 연습과 교육

4) 사회기술훈련(대표적으로 스포츠에 참여하는 것)

5) 약물 복용

5 16세까지의 아동과 청소년을 대상으로 하며 6 8주 동안 의 프로그램으로 진행된다. 나이가 같은 12 15명 정도가 한 그 룹을 이루게 되며 치료자가 각 그룹의 치료를 수행하게 된다. 여름방학 내내 같은 그룹의 아이들과 머물면서 그룹으로서 기능을 수행하며 친구들을 만들고 어른들과 적합하게 상호 
작용하는 법 등을 집중적으로 경험하게 된다. 방학 훈련 프로 그램에서는 모든 개입이 정상적인 아동과 청소년들의 활동 내 용 속에서 이루어진다는 점이 중요하다. 이러한 개입은 상담 사, 교사, 보조교사들에 의해 이루어지며 임상가의 지도, 관리 를 받게 된다. 아동뿐만 아니라 부모의 효과적인 양육 방식 또한 다루어지며 방학 훈련 프로그램 외의 상황에서 적용할 수 있게 된다. 방학 훈련 프로그램은 15 개 이상의 무작위 대조 실험이 진행되었고 그 효과가 검증되었다. ${ }^{265)}$

\section{인지행동치료}

인지행동치료는 인지적 개입과 행동적 개입의 요소들을 가 지는 여러 질환들을 조절, 관리하기 위한 접근 방법이다. 인지 행동치료는 생각, 감정, 행동이 서로 상관관계가 있으며 이 세가 지 중 한 부분이 바뀌게 되면 나머지 부분들이 개선될 것이라 는 전제를 기본으로 한다. 대부분의 인지행동치료는 환경에 대 한 개인의 반응을 중재하는 인지적 활동에 개입한다.

인지적 요소는 기능에 부정적인 영향을 주는 생각 양식을 찾는데 중점을 두며 치료적 작업은 이러한 부적응적 생각과 가정을 바꾸는 데 목적을 둔다. 인지행동치료에 쓰이는 인지 기 술들은 심리 교육(psychoeducation)과 인지 재구성이 있다. 심 리 교육은 아동과 부모에게 질병과 증상들에 대해 교육하고 인지행동치료가 어떠한 도움을 줄 수 있는지 교육하는 것이 다. 인지 재구성의 목표는 아동이 자기자신과 문제들을 다른 방식으로 생각하도록 하는 것이다. 자동 사고를 기록하고 인 지적 오류를 찾고 문제들을 재구성하며 자동 사고에 반하는 증거들을 찾는 활동 등이 포함된다.

행동적 요소는 자동 사고를 교정하는 데 도움을 주는 행동 적 기술들을 사용한다. 역할 놀이, 유관 강화(contingency reinforcement), 노출, 이완 훈련과 활동 계획 세우기 등이다. 역할 놀이는 치료자와 함께 배운 기술들을 연습하는 기회를 제공 하여 치료 세션 이외의 상황에서 기술을 사용하도록 도와준 다. 유관 강화는 치료 순응을 높이는 데 도움이 되는 보상 시스 템을 사용하는 것이다. 노출 요법은 불안장애를 가진 환아들 에게 도움이 되며 활동 계획은 우울증을 위한 인지행동치료 의 특이적 행동적 요소이다. 이완 훈련은 불안의 치료에 사용 되기도 한다. 행동적 요소들의 구체적인 내용으로는 미루기를 감소시키기 위한 행동 기술들, 의사소통 기술들(끼어들지 않 기, 능동적 경청 개선 등), 그리고 분노와 좌절을 관리하는 기 술 등이다. 치료자는 다음 치료 세션까지 숙제를 내주게 되는 데 숙제는 인지행동치료의 중요한 요소이다.

인지행동치료에서는 부모도 내원하여 같이 교육을 받게 되 는데 교육 주제가 무엇인지, 숙제를 어떻게 모니터링 할 것인 지, 치료 순응도를 높이기 위한 보상 시스템을 어떻게 사용할
것인지 등에 대한 것이다.

인지행동치료는 한때 아동 $\mathrm{ADHD}$ 치료에 효과적이라고 믿 어졌으나 그것을 뒷받침할 만한 연구는 많지 않다. 인지행동 치료에 대한 여러 메타분석 결과들을 보면 효과크기(effect size)가 $1 / 3 \mathrm{sd}$ 보다 작다. ${ }^{266-269)}$ 또한 인지행동치료에 대한 여 러 연구들의 효과에 대한 평가가 맹검 검사(blinded test)로 진 행이 어려워 편향(bias)이 생길 가능성이 많으며 $\mathrm{ADHD}$ 의 핵 심증상보다는 아동의 환경과의 상호관계 속에서 발생하는 여 러 문제들을 줄여줌으로써 효과를 나타낸다고 보는 경향이 있다. 이러한 한정된 효용성 때문에 인지행동치료는 MTA 치 료 프로토콜에 포함되지 않았다.

아동기 $\mathrm{ADHD}$ 에서는 인지적 접근이 다소 어렵기 때문에 인 지행동치료 효과가 떨어지는 것으로 나타나고 있으나 청소년 과 성인에서는 인지행동치료의 긍정적인 효과에 대한 연구들 이 보고되고 있다. 청소년을 대상으로 한 $\mathrm{ADHD}$ 인지행동치 료 연구의 여러 기능적 도메인에서 긍정적인 결과들이 나타났 다. $^{270-272)}$

68명의 ADHD 환아군을 대상으로 한 연구에서 인지행동치 료 시행 후 부모와 교사 보고, 학교 참여, 약물 순응도 등 여러 측면에서 유의한 호전결과가 나타났다. ${ }^{270)} 10$ 명의 $\mathrm{ADHD}$ 환아 군과 부모를 대상으로 한 연구에서도 마음챙김(mindfulness) 훈련을 시킨 경우 환아의 주의력 및 행동 문제, 집행기능 등 에 유의한 향상이 있었고 부모 훈육 스트레스 또한 감소하는 것으로 보고되었다. ${ }^{271)}$ 그리고 최근 여러 연구에서는 인지행동 치료가 성인 $\mathrm{ADHD}$ 환자들에게 효과적이라는 보고들이 있다.

\section{사회기술훈련}

사회적 문제가 $\mathrm{ADHD}$ 의 진단기준은 아니지만 사회적 기능 의 손상은 자주 나타난다. 특히 $\mathrm{ADHD}$ 를 가진 아동들에서 사 회기술훈련은 개인의 사회적 기술을 유지하고 향상시키는 데 목적이 있다.

사회기술훈련은 인지행동치료의 한 종류로써 치료자에 의 해 개별적으로 아동에게 교육할 수도 있으나, 그룹 형태를 구 성한 상태에서 기술들을 전달함으로써 아동이 직접적으로 그 들의 사회적 기술을 연습해 보는 기회를 제공하기도 한다. 아 동들은 사회적 상호관계 속에서 그들의 언어적 그리고 비언어 적 행동들을 어떻게 적용할 것인가를 배운다. 이것은 또한 사 회적 세상에 대한 아동의 인지적 평가 방식을 바꾸는 노력을 포함한다. 훈련은 주로 차례를 기다리거나, 대화 중 주제를 바 꾸는 시기나 다른 이들의 감정적 표현을 인지하는 것과 같은 사회적 상호관계에서 나타나는 미묘한 신호를 읽어내는 방법 을 가르치는 데 중점을 둔다. ${ }^{273)}$ 또한 사회적으로 평범한 것들, 사회적 규범, 다른 이들의 기대 등을 가르친다. 나누는 것, 대 
화를 해 나가는 것, 새 친구 사귀기, 게임을 할 때 규칙을 지키 고 차례를 기다리는 것, 화가 났을 때 기분은 안정시키는 방법, 감정을 알아차리기 등이다. 보편적으로 임상가는 아동에게 사 회기술훈련을 가르치게 되는데 토론과 역할 놀이 등을 통해 아동이 그 기술을 연습할 수 있게 한다. 세션 내의 수행을 통해 임상가는 아동의 행동을 바로잡아주며 아동의 성공적인 기술 의 사용을 강화한다. 세션당 60 분에서 90 분 정도로 주 1 회 시 행하며 커리큘럼에 따라 8 12주 정도의 기간 동안 훈련을 하 게 된다.

전통적인 방식의 사회기술훈련들이 ADHD에 동반되는 사 회적 결합을 호전시키는 데 효과적이라는 증명이 되지 않았지 만 최근 10 년 동안 여러 대안적인 사회기술훈련 기법들이 개발 되고 있다. 진료실 상황이 아닌 실제 생활에서 아동들이 친구 들과 상호작용하는 상황에 즉각적인 피드백을 줄 수 있도록 아동의 부모나 교사들을 훈련시키는 데 조금 더 초점을 맞추 고 있다.

\section{인지치료}

인지치료는 재활 과학과 뇌과학에서 뇌의 가소성에 대한 증 거들이 나타나면서, 정보를 처리하는 과업에 통제된 노출을 통 하여 $\mathrm{ADHD}$ 에 연관된 뇌의 핵심 연결망이 강화되고 인지 과 정이 개선될 수 있다는 관념을 전제로 하며 '계획적인 훈련과 연습을 통해 인지기능을 향상시키는 과정'으로 정의된다. ${ }^{274}$ 작 업기억 훈련(working memory training)과 같은 인지치료는 증상과 함께 기저의 신경심리학적 결함을 목표로 $\mathrm{ADHD}$ 를 가진 환자들에게 사용되는 치료법이다.

인지치료는 두 가지 종류가 있으며 하나는 과정에 기반을 둔 접근으로 다음과 같은 작업들의 암묵적(implicit) 실행을 반복해서 하는 것에 초점을 둔다. ${ }^{275)}$

1) 인지적 작업; 처리속도와 억제 등

2) 일차적 정신 능력; 귀납적 추론, 공간 지각, 삽화적 기억

3) 상위체계 인지 구성; 유동지능, 집행 기능 등

4) 주의력과 작업기억 등 전반적 인지
두 번째 방법은 전략에 기반을 둔 접근으로 다음과 같은 작 업들을 촉진하기 위해 명시적 과업 교육을 사용한다. ${ }^{274)}$

1) 상상이나 예행연습과 같은 세부적인 전략

2) 일반적인 초인지(metacognitive)적 기술의 수행

최근 $\mathrm{ADHD}$ 와 관련된 여러 연구들은 첫 번째 접근 방식에 중점을 두고 있다. 가장 흔하게 사용되는 인지치료의 종류들 을 Table 7에 정리하였다. ${ }^{276)}$

주로 컴퓨터를 사용하여 수행되며 작업기억 훈련 프로그램 의 일종인 cogmed(RoboMemo)의 경우 40분씩 90회의 훈련 기간을 가진다. 인지치료 이후 훈련하지 않은 다른 인지 영역 까지 근전이(near transfer)가 일어난다고 보고하였다.

$\mathrm{ADHD}$ 환아들을 대상으로 한 인지치료는 두 가지 관점이 있다. $\mathrm{ADHD}$ 의 원인이 신경정신적 결함에 의해 매개되기 때문 에 그러한 결함을 강화시켜주면 $\mathrm{ADHD}$ 증상이 줄고 연관된 문제들이 줄어들 것이라고 가정하고 인지치료를 $\mathrm{ADHD}$ 의 1 차 치료로 생각하는 관점이다. 또 하나의 관점은 인지치료가 핵심 $\mathrm{ADHD}$ 증상에 미치는 영향과는 독립적으로 $\mathrm{ADHD}$ 를 가진 환아들에게 흔히 관찰되는 신경심리학적 결함과 연관된 문제들을 줄여주는 부가적인 치료법으로 이해하는 것이다. 최근 수행된 메타분석 연구에서 $\mathrm{ADHD}$ 의 부주의 증상을 줄 여주는 것으로 나타났으나 대조군이 잘 통제된 연구들만 대상 으로 보면 그 효과가 약화되었다. 또한 객관적 검사에서 현저 하게 시각적 그리고 언어적 작업기억의 향상이 관찰되었으나 억제와 부주의성에는 효과가 없는 것으로 나타났다. 그리고 작업기억에 대한 인지치료의 효과가 학업적 수행의 결과로 이 어지지는 않았다. 따라서 인지치료는 1차 치료가 아닌 ADHD 에 대한 부가적인 치료법으로 사용해 볼 수 있겠다.

\section{뉴로피드백}

$\mathrm{ADHD}$ 환자들은 electroencephalogram(EEG)상 theta파 의 활동성이 크고 beta, alpha파의 활동성이 작은 것으로 알 려져 있다. 그중 theta/beta 비율의 이상은 ADHD 환아들에 서 가장 중요한 소견 중 하나이다. 뉴로피드백은 앞서 언급한

Table 7. Most common computerized cognitive training programs

\begin{tabular}{ll}
\hline \multicolumn{1}{c}{ Name } & \multicolumn{1}{c}{ Target } \\
\hline AIXTENT (CogniPlus) & Attention: selective, divided, focused and constant \\
Captain's log & Attention, working memory, visuomotor function, problem solving \\
Cogmed (RoboMemo) & Visuospatial and spatioverbal working memory \\
CogniPlus & Attention, working memory, visuomotor function, executive functions, long term memory \\
Locu tour & Attention, visual, verbal attention, executive function, acoustic and visual memory \\
Pay attention! & Attention \\
RehaCom & Attention, memory, executive fucntions, visuomotor functions \\
REMINDER (partially computerized) & Memory storage and recall strategies \\
\hline Adapted from Karch et al. Dtsch Arztebl Int 2013;1 10:643-652
\end{tabular}

Adapted from Karch et al. Dtsch Arztebl Int 2013;1 10:643-652 ${ }^{276)}$ 
2가지의 EEG 이상 소견을 개선시키기 위해 개발되었다. 뉴로피드백 훈련은 2가지 유형으로 분류된다. 첫 번째는 Sensory motor rhythm을 기반으로 하여 전두/측두엽의 beta 파의 활동을 증가시키고 theta파의 활동을 감소시키도록 훈 련하는 방법이다. ${ }^{27)}$ 두 번째는 느린 피질 전위(slow cortical potential) 훈련이다. ${ }^{278)}$ 우리나라의 경우 beta-sensory motor rhythm 훈련을 주로 사용하며 15 20회기를 기준으로 실시한 다. 이것은 주의력과 집중력을 향상시키고 자가-조절하는 생 리적 방법을 제공한다. ${ }^{279)} 102$ 명의 $\mathrm{ADHD}$ 환아들을 대상으 로 시행한 무작위 대조 실험 연구에서 뉴로피드백 치료군이 컴퓨터 주의력 기술훈련군에 비해 부모와 교사 보고에서 유 의미한 호전을 보고하였다. ${ }^{280)}$ 우리나라에서는 뉴로피드백을 시행한 후 아동, 부모, 교사 보고에서 의미 있는 향상을 보인 다는 여러 연구 보고들이 있다. ${ }^{281,282)}$ 하지만 대부분의 연구에 서 theta와 beta의 유의미한 변화를 보여주지는 못했다. 또한 뉴로피드백군과 위약 피드백군을 비교한 이중맹검 무작위 대 조 실험 연구에서는 뉴로피드백과 위약 피드백군 간의 유의미 한 치료 효과의 차이를 밝혀내지 못하였다. ${ }^{283)}$

이러한 결과들을 토대로 뉴로피드백의 효과에 대해 의문을 제기할 수도 있으나 여러 연구에서 보고하고 있는 치료 후 부 모나 교사들의 평정결과의 긍정적인 변화를 볼 때 뉴로피드 백 훈련 효과에 대한 간접적인 증거를 확인했다고 볼 수 있다. 앞으로 효과를 검증하기 위한 훈련에 대한 구조화와 표준화, 그리고 치료자의 숙련도를 높이기 위한 체계적인 교육, 효과 를 검증하기 위한 구체적이고 효과적인 연구 설계들이 시행되 어야 할 것이다.

\section{성인 $\mathrm{ADHD}$ 환자의 인지행동치료}

$\mathrm{ADHD}$ 의 성인 유병률은 $4.4 \%$ 정도이다. ${ }^{284)}$ 약물치료를 받 는 25 50\%의 환자들은 핵심증상의 호전을 보이나 교육, 직업, 생활 기술(운전 등), 대인관계 등 삶의 여러 영역에서 잔존 증상 을 가진다. ${ }^{252,285)}$ 또한 아동에 비해 삶 속에서 책임과 의무가 많 기 때문에 아동과는 다른 양상의 문제들과 직면하게 되며 아동 과는 다른 정신 사회적 치료가 필요하다.

$\mathrm{ADHD}$ 는 부주의, 과잉행동, 충동성의 주요 증상으로 인해 지속적인 주의력, 억제 조절능력, 작업기억, 동기의 부족 등이 나타난다. 이러한 결핍들은 기능적 저하로 이어지며 고기능적 조직화와 계획 세우기 전략 등과 같이 증상과 관련된 어려움 들을 강화시킨다. 이러한 기저에 깔린 신경심리적 결함이 $\mathrm{ADHD}$ 를 가진 환자들로 하여금 그들이 필요한 보상전략을 사용하고 습득하는 것을 방해하고 지속적인 증상과 기능적 결함의 악화를 가져온다. 아동기부터 지속되는 만성적 기능 결 함의 결과로 $\mathrm{ADHD}$ 성인 환자들은 여러 실패와 만성적인 자기
능력 이하의 성취를 경험한다. 또한 성인 환자들은 가족, 교사, 동료들로부터 부정적인 사회적 피드백을 받기 쉽다. 이러한 경 험들은 비적응적인 부정적 인지와 믿음들을 만들어내고 이것 들이 동기를 저하시키고 회피 행동을 만들어내며 기분 불안정 에 영향을 주며 이러한 순환고리를 악화시킨다는 것이다. 이 러한 측면에서 볼 때 심리 교육(psychoeducation), 인지행동 치료, 삶을 계획하는 것을 도와주는 방법 등이 효과가 있 다. ${ }^{285-287)}$ 약물치료 단독으로는 성인 $\mathrm{ADHD}$ 환자들이 가지는 여러 문제들을 안정화시키는 데 효과적이지 않다.

성인에게 인지행동치료가 효과적이라는 연구들이 많이 보고 되고 있다. 성인 $\mathrm{ADHD}$ 인지행동치료는 인지를 바꾸기보다는 기술을 만들고 특성 기술을 가르치며 행동적 기술을 가르치 는 데 조금 더 방향이 잡혀 있다. ${ }^{288)}$ 또한 발견된 현실적 문제 에 대한 문제해결 기술을 가르치는 데 목적이 있다. ${ }^{285,289)}$ 세부 항목들을 살펴보면 질환을 받아들임, 시간 관리, 한 번에 한 가지 목표로 활동에 제한을 둠, 가정, 직장, 경제적인 것들을 체계화하고 관리하는 기술, 대인관계, 직업적 어려움 다루기, 일을 시작하고 끝내는 것, $\mathrm{ADHD}$ 와 연관된 감정적 반응들의 이해 등이 있다.

이러한 항목들을 실천하기 위해 인지행동치료에서 다음과 같은 기술들을 사용한다.

1) 일정 관리 및 일상 과제 우선 순위 정하기 등 외현 기술 훈련

2) 보상책략/강화의 효율적 사용

3) 감정적 방해요소 인지 및 저항하기

이러한 치료들은 $\mathrm{ADHD}$ 의 핵심증상을 치료하거나 성인 $\mathrm{ADHD}$ 치료의 단독요법으로 추천되지는 않는다. $\mathrm{ADHD}$ 치 료 시 잔존 증상, 또는 연관된 공존 질환의 치료에 효과적이 다. 인지행동치료+약물치료와 약물치료 단독 치료군의 치료 효과를 비교한 연구에서 인지행동치료+약물치료군에서 $\mathrm{ADHD}$ 증상, 불안, 우울점수의 현저한 호전결과가 나타났다. 285$)$ 약물 치료를 받고 있는 성인 환자군을 대상으로 한 무작위 대조 실험 연구에서도 인지행동치료를 받는 군이 일반군에 비해 $\mathrm{ADHD}$ 증상과 공존 문제들의 호전을 가져오는 것으로 보고 하였다. ${ }^{251)}$ 그 외 성인에서 대뇌 피질의 집행기능을 강화시키 는 대체 전략들로써 meta-cognitive training가 있다. ${ }^{20)}$

중심 단어:주의력결핍 과잉행동장애; 임상진료지침; 진단; 치료.

\section{Acknowledgments}

This work was supported by the Korean Health Technology R\&D Project, Ministry of Health and Welfare, Republic of Korea (grant number A120013). 


\section{Conflicts of Interest}

The authors have no financial conflicts of interest.

\section{REFERENCES}

1) American Psychiatric Association. Diagnostic and statistical manual of mental disorders (DSM-5). 5th ed. Washington, DC: American Psychiatric Assocition;2013.

2) The Royal Australasian College of Physicians. Draft Australian Guidelines on Attention Deficit Hyperactivity Disorder (ADHD). St. Kilda: RACP;2009.

3) Canadian Attention Deficit Hyperactivity Disorder Resource Alliance. Canadian ADHD practice guidelines. 3th ed. Toronto, ON: CADDRA;2011.

4) Cho SC, Kim BN, Kim JW, Kim HW, Choi HJ, Jung SW, et al. The reliability and validity of diagnostic interview schedule for children version IV-Korean version (DISC-IV). J Korean Acad Child Adolesc Psychiatry 2007;18:138-144.

5) Kim YS, Cheon KA, Kim BN, Chang SA, Yoo HJ, Kim JW, et al. The reliability and validity of kiddie-schedule for affective disorders and schizophrenia-present and lifetime version- Korean version (K-SADS-PL-K). Yonsei Med J 2004;45:81-89.

6) Jang SJ, Suh DS, Byun HJ. Normative study of the K-ARS (Korean ADHD Rating Scale) for parents. J Korean Acad Child Adolesc Psychiatry 2007;18:38-48.

7) Kim Y, Jung HY, Roh S. Rating Scales for Attention-Deficit Hyperactivity Disorder in Adults. J Korean Acad Child Adolesc Psychiatry 2010;21:11-16.

8) Ward MF, Wender PH, Reimherr FW. The Wender Utah Rating Scale: an aid in the retrospective diagnosis of childhood attention deficit hyperactivity disorder. Am J Psychiatry 1993;150:885-890.

9) Barkley RA, Murphy KR. Attention-deficit hyperactivity disorder: a clinical workbook. 2nd ed. New York: Guilford Press; 1998.

10) Chang MS. The validation of Conners' adult ADHD Scale-Korean (Shot version). Kor J Clin Psychol 2008;27:499-513.

11) Kim EJ. The validation of Korean adult ADHD Scale (K-AADHDS). Kor J Clin Psychol 2003;22:897-911.

12) Corkum PV, Siegel LS. Is the continuous performance task a valuable research tool for use with children with attention-deficit hyperactivity disorder? J Child Psychol Psychiatry 1993;34:1217-1239.

13) Seo JM, Lee JS, Kim SY, Kim HW. Diagnostic significance of comprehensive attention test in children and adolescents with attention-deficit hyperactivity disorder. J Korean Acad Child Adolesc Psychiatry 2011;22:246-252.

14) Thaler NS, Bello DT, Etcoff LM. WISC-IV profiles are associated with differences in symptomatology and outcome in children with ADHD. J Atten Disord 2013;17:291-301.

15) Min JW, Lee WH, Hong MH, Bahn GH. A pilot study of the usefulness of intelligence test in assessment of attention-deficit hyperactivity disorder. J Korean Acad Child Adolesc Psychiatry 2012; 23:196-203.

16) Faraone SV, Khan SA. Candidate gene studies of attention-deficit/ hyperactivity disorder. J Clin Psychiatry 2006;67 Suppl 8:13-20.

17) Park S, Jeong HW, Kim BN, Cho SC, Kim JW, Shin MS, et al. Perinatal and developmental risk factors of ADHD children diagnosed with a structured interview. J Korean Acad Child Adolesc Psychiatry 2012;23:181-187.

18) Kim HW, Cho SC, Kim BN, Kim JW, Shin MS, Kim Y. Perinatal and familial risk factors are associated with full syndrome and subthreshold attention-deficit hyperactivity disorder in a Korean community sample. Psychiatry Investig 2009;6:278-285.

19) Hesdorffer DC, Ludvigsson P, Olafsson E, Gudmundsson G, Kjartansson $\mathrm{O}$, Hauser WA. ADHD as a risk factor for incident unprovoked seizures and epilepsy in children. Arch Gen Psychiatry 2004;61:731-736.
20) Socanski D, Aurlien D, Herigstad A, Thomsen PH, Larsen TK. Epilepsy in a large cohort of children diagnosed with attention deficit/hyperactivity disorders (ADHD). Seizure 2013;22:651-655.

21) Caplan R, Siddarth P, Stahl L, Lanphier E, Vona P, Gurbani S, et al. Childhood absence epilepsy: behavioral, cognitive, and linguistic comorbidities. Epilepsia 2008;49:1838-1846.

22) Snyder SM, Hall JR, Cornwell SL, Quintana H. Review of clinical validation of ADHD behavior rating scales. Psychol Rep 2006; 99:363-378.

23) Loo SK, Makeig S. Clinical utility of EEG in attention-deficit/hyperactivity disorder: a research update. Neurotherapeutics 2012;9: 569-587.

24) Snyder SM, Quintana H, Sexson SB, Knott P, Haque AF, Reynolds DA. Blinded, multi-center validation of EEG and rating scales in identifying ADHD within a clinical sample. Psychiatry Res 2008; 159:346-358.

25) Sadek J. A Clinician's Guide to ADHD. Cham: Springer;2014.

26) Lahey BB, Pelham WE, Loney J, Kipp H, Ehrhardt A, Lee SS, et al. Three-year predictive validity of DSM-IV attention deficit hyperactivity disorder in children diagnosed at 4-6 years of age. Am J Psychiatry 2004;161:2014-2020.

27) Riddle MA, Yershova K, Lazzaretto D, Paykina N, Yenokyan G, Greenhill L, et al. The preschool Attention-Deficit/Hyperactivity Disorder Treatment Study (PATS) 6-year follow-up. J Am Acad Child Adolesc Psychiatry 2013;52:264-278.e2.

28) Egger HL, Kondo D, Angold A. The epidemiology and diagnostic issues in preschool attention-deficit/ hyperactivity disorder: a review. Infants and Young Children 2006;19:109-122.

29) Polanczyk G, Jensen P. Epidemiologic considerations in attention deficit hyperactivity disorder: a review and update. Child Adolesc Psychiatr Clin N Am 2008;17:245-260, vii.

30) Polanczyk G, de Lima MS, Horta BL, Biederman J, Rohde LA. The worldwide prevalence of ADHD: a systematic review and metaregression analysis.Am J Psychiatry. 2007;164:942-948.

31) Safer DJ, Zito JM. Pharmacoepidemiology of methylphenidate and other stimulants for the treatment of attention deficit hyperactivity disorder. In: Greenhill LL, Osman BB, editors. Ritalin: theory and practice. New York: Mary Ann Liebert;2000. p.7-26.

32) Robison LM, Skaer TL, Sclar DA, Galin RS. Is attention deficit hyperactivity disorder increasing among girls in the US? Trends in diagnosis and the prescribing of stimulants. CNS Drugs 2002;16: 129-137.

33) Brault MC, Lacourse É. Prevalence of prescribed attention-deficit hyperactivity disorder medications and diagnosis among Canadian preschoolers and school-age children: 1994-2007. Can J Psychiatry 2012;57:93-101.

34) McCarthy S, Wilton L, Murray ML, Hodgkins P, Asherson P, Wong IC. The epidemiology of pharmacologically treated attention deficit hyperactivity disorder (ADHD) in children, adolescents and adults in UK primary care. BMC Pediatr 2012;12:78.

35) Polanczyk GV, Willcutt EG, Salum GA, Kieling C, Rohde LA. ADHD prevalence estimates across three decades: an updated systematic review and meta-regression analysis. Int J Epidemiol 2014; 43:434-442.

36) Kim JY, Ahn DH, Shin YJ. An epidemiological study of attentiondeficits hyperactivity disorder and learning disabilities in a rural area. J Korean Neuropsychiatr Assoc 1999;38:784-793.

37) Cho SC, Shin YO. Prevalence of disruptive behavior disorders. J Korean Acad Child Adolesc Psychiatry 1994,5:141-149.

38) Yang SJ, Cheong S, Hong SD. Prevalence and correlates of attention deficit hyperactivity disorder: school-based mental health services in Seoul. J Korean Neuropsychiatr Assoc 2006;45:69-76.

39) Kim DW, Lee JE, Jung WC, Nam KC, Bang YW, Kim SJ, et al. Cross sectional study on the prevalence of attention deficit hyperactivity disorder and associated factors among elementary school 
students living nearby Shihwa-Banwol industrial complex. Korean J Occup Environ Med 2012;24:252-262.

40) Willcutt EG. The prevalence of DSM-IV attention-deficit/hyperactivity disorder: a meta-analytic review. Neurotherapeutics 2012; 9:490-499.

41) Faraone SV, Biederman J, Weber W, Russell RL. Psychiatric, neuropsychological, and psychosocial features of DSM-IV subtypes of attention-deficit/hyperactivity disorder: results from a clinically referred sample. J Am Acad Child Adolesc Psychiatry 1998;37: 185-193.

42) Hill JC, Schoener EP. Age-dependent decline of attention deficit hyperactivity disorder. Am J Psychiatry 1996;153:1143-1146.

43) Simon V, Czobor P, Bálint S, Mészáros A, Bitter I. Prevalence and correlates of adult attention-deficit hyperactivity disorder: metaanalysis. Br J Psychiatry 2009;194:204-211.

44) Kessler RC, Adler L, Barkley R, Biederman J, Conners CK, Demler $\mathbf{O}$, et al. The prevalence and correlates of adult ADHD in the United States: results from the National Comorbidity Survey Replication. Am J Psychiatry 2006;163:716-723.

45) Park S, Cho MJ, Chang SM, Jeon HJ, Cho SJ, Kim BS, et al. Prevalence, correlates, and comorbidities of adult ADHD symptoms in Korea: results of the Korean epidemiologic catchment area study. Psychiatry Res 2011;186:378-383.

46) Kwak YS, Jung YE, Kim MD. Prevalence and correlates of attention-deficit hyperactivity disorder symptoms in Korean college students. Neuropsychiatr Dis Treat 2015;11:797-802.

47) Lara C, Fayyad J, de Graaf R, Kessler RC, Aguilar-Gaxiola S, Angermeyer M, et al. Childhood predictors of adult attention-deficit/ hyperactivity disorder: results from the World Health Organization World Mental Health Survey Initiative. Biol Psychiatry 2009;65: 46-54.

48) Kessler RC, Green JG, Adler LA, Barkley RA, Chatterji S, Faraone SV, et al. Structure and diagnosis of adult attention-deficit/hyperactivity disorder: analysis of expanded symptom criteria from the Adult ADHD Clinical Diagnostic Scale. Arch Gen Psychiatry 2010; 67:1168-1178

49) Faraone SV, Biederman J, Mick E. The age-dependent decline of attention deficit hyperactivity disorder: a meta-analysis of followup studies. Psychol Med 2006;36:159-165.

50) Biederman J, Mick E, Faraone SV. Age-dependent decline of symptoms of attention deficit hyperactivity disorder: impact of remission definition and symptom type. Am J Psychiatry 2000;157:816818.

51) Barkley RA, Murphy KR, Dupaul GI, Bush T. Driving in young adults with attention deficit hyperactivity disorder: knowledge, performance, adverse outcomes, and the role of executive functioning. J Int Neuropsychol Soc 2002;8:655-672.

52) Robin L, Eleanor Payson. The impact of ADHD on marriage. [cited 2015 Nov 25]. Available from: http://www.adders.org/partners1. pdf.

53) Mannuzza S, Klein RG, Moulton JL 3rd. Lifetime criminality among boys with attention deficit hyperactivity disorder: a prospective follow-up study into adulthood using official arrest records. Psychiatry Res 2008;160:237-246.

54) Biederman J, Petty CR, Fried R, Kaiser R, Dolan CR, Schoenfeld $\mathrm{S}$, et al. Educational and occupational underattainment in adults with attention-deficit/hyperactivity disorder: a controlled study. J Clin Psychiatry 2008;69:1217-1222.

55) de Graaf R, Kessler RC, Fayyad J, ten Have M, Alonso J, Angermeyer M, et al. The prevalence and effects of adult attention-deficit/hyperactivity disorder (ADHD) on the performance of workers: results from the WHO World Mental Health Survey Initiative. Occup Environ Med 2008;65:835-842.

56) Akutagava-Martins GC, Salatino-Oliveira A, Kieling CC, Rohde LA, Hutz MH. Genetics of attention-deficit/hyperactivity disor- der: current findings and future directions. Expert Rev Neurother 2013;13:435-445.

57) Anney RJ, Lasky-Su J, O’Dúshláine C, Kenny E, Neale BM, Mulligan A, et al. Conduct disorder and ADHD: evaluation of conduct problems as a categorical and quantitative trait in the international multicentre ADHD genetics study. Am J Med Genet B Neuropsychiatr Genet 2008;147B(8):1369-1378.

58) Biederman J, Faraone SV, Petty C, Martelon M, Woodworth KY, Wozniak J. Further evidence that pediatric-onset bipolar disorder comorbid with ADHD represents a distinct subtype: results from a large controlled family study. J Psychiatr Res 2013;47:15-22.

59) Rommelse NN, Franke B, Geurts HM, Hartman CA, Buitelaar JK. Shared heritability of attention-deficit/hyperactivity disorder and autism spectrum disorder. Eur Child Adolesc Psychiatry 2010; 19:281-295.

60) Faraone SV, Mick E. Molecular genetics of attention deficit hyperactivity disorder. Psychiatr Clin North Am 2010;33:159-180.

61) Gizer IR, Ficks $C$, Waldman ID. Candidate gene studies of ADHD: a meta-analytic review. Hum Genet 2009;126:51-90.

62) Zhou K, Dempfle A, Arcos-Burgos M, Bakker SC, Banaschewski $\mathrm{T}$, Biederman J, et al. Meta-analysis of genome-wide linkage scans of attention deficit hyperactivity disorder. Am J Med Genet B Neuropsychiatr Genet 2008;147B:1392-1398.

63) Cross-Disorder Group of the Psychiatric Genomics Consortium, Lee SH, Ripke S, Neale BM, Faraone SV, Purcell SM, et al. Genetic relationship between five psychiatric disorders estimated from genome-wide SNPs. Nat Genet 2013;45:984-994.

64) Neale BM, Medland SE, Ripke S, Asherson P, Franke B, Lesch KP, et al. Meta-analysis of genome-wide association studies of attention-deficit/hyperactivity disorder. J Am Acad Child Adolesc Psychiatry 2010;49:884-897.

65) Franke B, Neale BM, Faraone SV. Genome-wide association studies in ADHD. Hum Genet 2009;126:13-50.

66) Banerjee TD, Middleton F, Faraone SV. Environmental risk factors for attention-deficit hyperactivity disorder. Acta Paediatr 2007; 96:1269-1274.

67) Barkley RA, Fischer M, Smallish L, Fletcher K. The persistence of attention-deficit/hyperactivity disorder into young adulthood as a function of reporting source and definition of disorder. J Abnorm Psychol 2002;111:279-289.

68) Galéra C, Côté SM, Bouvard MP, Pingault JB, Melchior M, Michel G, et al. Early risk factors for hyperactivity-impulsivity and inattention trajectories from age 17 months to 8 years. Arch Gen Psychiatry 2011;68:1267-1275.

69) Pingault JB, Tremblay RE, Vitaro F, Carbonneau R, Genolini C, Falissard B, et al. Childhood trajectories of inattention and hyperactivity and prediction of educational attainment in early adulthood: a 16-year longitudinal population-based study. Am J Psychiatry 2011;168:1164-1170.

70) Pliszka S; AACAP Work Group on Quality Issues. Practice parameter for the assessment and treatment of children and adolescents with attention-deficit/hyperactivity disorder. J Am Acad Child Adolesc Psychiatry 2007;46:894-921.

71) Dopheide JA, Pliszka SR. Attention-deficit-hyperactivity disorder: an update. Pharmacotherapy 2009;29:656-679.

72) Nagin D, Tremblay RE. Trajectories of boys' physical aggression, opposition, and hyperactivity on the path to physically violent and nonviolent juvenile delinquency. Child Dev 1999;70:1181-1196.

73) Larsson H, Dilshad R, Lichtenstein P, Barker ED. Developmental trajectories of DSM-IV symptoms of attention-deficit/hyperactivity disorder: genetic effects, family risk and associated psychopathology. J Child Psychol Psychiatry 2011;52:954-963.

74) Sagvolden T, Johansen EB, Aase H, Russell VA. A dynamic developmental theory of attention-deficit/hyperactivity disorder (ADHD) predominantly hyperactive/impulsive and combined subtypes. Be- 
hav Brain Sci 2005;28:397-419; discussion 419-468.

75) García-Castellar R, Presentación-Herrero MJ, Siegenthaler-Hierro R, Miranda-Casas A. [The sociometric status of children with the combined subtype of attention deficit hyperactivity disorder]. Rev Neurol 2006;42 Suppl 2:S13-S17.

76) Eiraldi RB, Power TJ, Nezu CM. Patterns of comorbidity associated with subtypes of attention-deficit/hyperactivity disorder among 6- to 12-year-old children. J Am Acad Child Adolesc Psychiatry 1997;36:503-514.

77) Tzang RF, Chang YC, Liu SI. The association between children's ADHD subtype and parenting stress and parental symptoms. Int J Psychiatry Clin Pract 2009;13:318-325.

78) Willcutt EG, Nigg JT, Pennington BF, Solanto MV, Rohde LA, Tannock R, et al. Validity of DSM-IV attention deficit/hyperactivity disorder symptom dimensions and subtypes. J Abnorm Psychol 2012;121:991-1010.

79) Kindlon D, Mezzacappa E, Earls F. Psychometric properties of impulsivity measures: temporal stability, validity and factor structure. J Child Psychol Psychiatry 1995;36:645-661.

80) Babinski LM, Hartsough CS, Lambert NM. Childhood conduct problems, hyperactivity-impulsivity, and inattention as predictors of adult criminal activity. J Child Psychol Psychiatry 1999;40:347355.

81) Polderman TJ, Boomsma DI, Bartels M, Verhulst FC, Huizink AC. A systematic review of prospective studies on attention problems and academic achievement. Acta Psychiatr Scand 2010;122:271284.

82) Maedgen JW, Carlson CL. Social functioning and emotional regulation in the attention deficit hyperactivity disorder subtypes. $\mathrm{J}$ Clin Child Psychol 2000;29:30-42.

83) Boonstra AM, Oosterlaan J, Sergeant JA, Buitelaar JK. Executive functioning in adult ADHD: a meta-analytic review. Psychol Med 2005;35:1097-1108.

84) Welsh MC, Pennington BF. Assessing frontal lobe functioning in children: views from developmental psychology. Dev Neuropsychol 1988;4:199-230.

85) Diamond A. Executive functions. Annu Rev Psychol 2013;64:135168.

86) Willcutt EG, Doyle AE, Nigg JT, Faraone SV, Pennington BF. Validity of the executive function theory of attention-deficit/hyperactivity disorder: a meta-analytic review. Biol Psychiatry 2005;57: 1336-1346.

87) Kasper LJ, Alderson RM, Hudec KL. Moderators of working memory deficits in children with attention-deficit/hyperactivity disorder (ADHD): a meta-analytic review. Clin Psychol Rev 2012; 32:605-617.

88) Barkley RA. Behavioral inhibition, sustained attention, and executive functions: constructing a unifying theory of ADHD. Psychol Bull 1997;121:65-94.

89) Rapport MD, Chung KM, Shore G, Isaacs P. A conceptual model of child psychopathology: implications for understanding attention deficit hyperactivity disorder and treatment efficacy. J Clin Child Psychol 2001;30:48-58.

90) Baddeley A. Working memory, thought, and action. New York: Oxford University Press;2007.

91) Martinussen R, Hayden J, Hogg-Johnson S, Tannock R. A metaanalysis of working memory impairments in children with attention-deficit/hyperactivity disorder. J Am Acad Child Adolesc Psychiatry 2005;44:377-384.

92) Haenlein M, Caul WF. Attention deficit disorder with hyperactivity: a specific hypothesis of reward dysfunction. J Am Acad Child Adolesc Psychiatry 1987;26:356-362.

93) Luman M, Oosterlaan J, Sergeant JA. The impact of reinforcement contingencies on AD/HD: a review and theoretical appraisal. Clin Psychol Rev 2005;25:183-213.
94) Hoerger ML, Mace FC. A computerized test of self-control predicts classroom behavior. J Appl Behav Anal 2006;39:147-159.

95) Antrop I, Stock P, Verté S, Wiersema JR, Baeyens D, Roeyers H. ADHD and delay aversion: the influence of non-temporal stimulation on choice for delayed rewards. J Child Psychol Psychiatry 2006;47:1152-1158.

96) Sonuga-Barke EJ, Sergeant JA, Nigg J, Willcutt E. Executive dysfunction and delay aversion in attention deficit hyperactivity disorder: nosologic and diagnostic implications. Child Adolesc Psychiatr Clin N Am 2008;17:367-384, ix.

97) Klotz JM, Johnson MD, Wu SW, Isaacs KM, Gilbert DL. Relationship between reaction time variability and motor skill development in ADHD. Child Neuropsychol 2012;18:576-585.

98) Adams ZW, Roberts WM, Milich R, Fillmore MT. Does response variability predict distractibility among adults with attention-deficit/hyperactivity disorder? Psychol Assess 2011;23:427-436.

99) Verté S, Geurts HM, Roeyers H, Oosterlaan J, Sergeant JA. Executive functioning in children with autism and Tourette syndrome. Dev Psychopathol 2005;17:415-445.

100) Kaiser S, Roth A, Rentrop M, Friederich HC, Bender S, Weisbrod M. Intra-individual reaction time variability in schizophrenia, depression and borderline personality disorder. Brain Cogn 2008; 66:73-82.

101) Bora E, Vahip S, Akdeniz F. Sustained attention deficits in manic and euthymic patients with bipolar disorder. Prog Neuropsychopharmacol Biol Psychiatry 2006;30:1097-1102.

102) Segalowitz SJ, Dywan J, Unsal A. Attentional factors in response time variability after traumatic brain injury: an ERP study. J Int Neuropsychol Soc 1997;3:95-107.

103) Kofler MJ, Rapport MD, Sarver DE, Raiker JS, Orban SA, Friedman LM, et al. Reaction time variability in ADHD: a meta-analytic review of 319 studies. Clin Psychol Rev 2013;33:795-811.

104) Martel MM. Research review: a new perspective on attention-deficit/hyperactivity disorder: emotion dysregulation and trait models. J Child Psychol Psychiatry 2009;50:1042-1051.

105) Yuill N, Lyon J. Selective difficulty in recognising facial expressions of emotion in boys with ADHD. General performance impairments or specific problems in social cognition? Eur Child Adolesc Psychiatry 2007;16:398-404.

106) Walcott CM, Landau S. The relation between disinhibition and emotion regulation in boys with attention deficit hyperactivity disorder. J Clin Child Adolesc Psychol 2004;33:772-782.

107) Barkley RA. ADHD and the Nature of Self-control. New York: The Guilford Press; 1997.

108) Berlin L, Bohlin G, Nyberg L, Janols LO. How well do measures of inhibition and other executive functions discriminate between children with ADHD and controls? Child Neuropsychol 2004;10: 1-13.

109) Blaskey LG, Harris LJ, Nigg JT. Are sensation seeking and emotion processing related to or distinct from cognitive control in children with ADHD? Child Neuropsychol 2008;14:353-371.

110) Barkley RA. Attention-deficit hyperactivity disorder: a handbook for diagnosis and treatment. New York: Guilford Publications;2014.

111) Toplak ME, Dockstader C, Tannock R. Temporal information processing in ADHD: findings to date and new methods. J Neurosci Methods 2006;151:15-29.

112) Bergström K, Bille B. Computed tomography of the brain in children with minimal brain damage: a preliminary study of 46 children. Neuropadiatrie 1978;9:378-384.

113) Thompson JS, Ross RJ, Horwitz SJ. The role of computed axial tomography in the study of the child with minimal brain dysfunction. J Learn Disabil 1980;13:334-337.

114) Pontius AA. Dysfunction patterns analogous to frontal lobe system and caudate nucleus syndromes in some groups of minimal brain dysfunction. J Am Med Womens Assoc 1973;26:285-292. 
115) Giedd JN, Blumenthal J, Molloy E, Castellanos FX. Brain imaging of attention deficit/hyperactivity disorder. Ann N Y Acad Sci 2001; 931:33-49.

116) Mannuzza S, Klein RG, Bessler A, Malloy P, LaPadula M. Adult outcome of hyperactive boys. Educational achievement, occupational rank, and psychiatric status. Arch Gen Psychiatry 1993;50: $565-576$.

117) Greydanus DE, Pratt HD, Patel DR. Attention deficit hyperactivity disorder across the lifespan: the child, adolescent, and adult. Dis Mon 2007;53:70-131

118) Conners CK, Erhardt D, Sparrow E. Conners' Adult ADHD Rating Scales (CAARS). Toronto: MHS;1999.

119) Brown TE. Brown Attention-Deficit Disorder Scales ${ }^{\circledR}$ (BrownADD Scales). San Antonio, TX: The Psychological Corporation; 1996.

120) McCann BS, Scheele L, Ward N, Roy-Byrne P. Discriminant validity of the Wender Utah Rating Scale for attention-deficit/hyperactivity disorder in adults. J Neuropsychiatry Clin Neurosci 2000;12: 240-245.

121) Schmitt J, Romanos M, Schmitt NM, Meurer M, Kirch W. Atopic eczema and attention-deficit/hyperactivity disorder in a population-based sample of children and adolescents. JAMA 2009;301: 724-726.

122) Reyero F, Ponce G, Rodriguez-Jimenez R, Fernandez-Dapica $P$, Taboada D, Martin V, et al. High frequency of childhood ADHD history in women with fibromyalgia. Eur Psychiatry 2011;26:482483.

123) Cortese S, Faraone SV, Konofal E, Lecendreux M. Sleep in children with attention-deficit/hyperactivity disorder: meta-analysis of subjective and objective studies. J Am Acad Child Adolesc Psychiatry 2009;48:894-908.

124) Pelsser LM, Buitelaar JK, Savelkoul HF. ADHD as a (non) allergic hypersensitivity disorder: a hypothesis. Pediatr Allergy Immunol 2009;20:107-112.

125) Arruda MA, Guidetti V, Galli F, Albuquerque RC, Bigal ME. Migraine, tension-type headache, and attention-deficit/hyperactivity disorder in childhood: a population-based study. Postgrad Med 2010;122:18-26.

126) Shaw P, Lerch J, Greenstein D, Sharp W, Clasen L, Evans A, et al. Longitudinal mapping of cortical thickness and clinical outcome in children and adolescents with attention-deficit/hyperactivity disorder. Arch Gen Psychiatry 2006;63:540-549.

127) Kessler RC, Adler L, Ames M, Demler O, Faraone S, Hiripi, et al. The World Health Organization Adult ADHD Self-Report Scale (ASRS): a short screening scale for use in the general population. Psychol Med 2005;35:245-256.

128) Biederman J, Faraone SV, Spencer T, Wilens T, Mick E, Lapey KA. Gender differences in a sample of adults with attention deficit hyperactivity disorder. Psychiatry Res 1994;53:13-29.

129) Barkley RA, Murphy KR. Attention-deficit hyperactivity disorder: a clinical workbook. New York: Guilford Press;1998.

130) Solanto MV, Marks DJ, Mitchell KJ, Wasserstein J, Kofman MD. Development of a new psychosocial treatment for adult ADHD. J Atten Disord 2008;11:728-736.

131) Tian L, Jiang T, Liang M, Zang Y, He Y, Sui M, et al. Enhanced resting-state brain activities in ADHD patients: a fMRI study. Brain Dev 2008;30:342-348.

132) Castellanos FX, Margulies DS, Kelly C, Uddin LQ, Ghaffari M, Kirsch A, et al. Cingulate-precuneus interactions: a new locus of dysfunction in adult attention-deficit/hyperactivity disorder. Biol Psychiatry 2008;63:332-337.

133) Rubia K, Cubillo A, Smith AB, Woolley J, Heyman I, Brammer MJ. Disorder-specific dysfunction in right inferior prefrontal cortex during two inhibition tasks in boys with attention-deficit hyperactivity disorder compared to boys with obsessive-compulsive disorder. Hum Brain Mapp 2010;31:287-299.

134) Elkins IJ, McGue M, Iacono WG. Prospective effects of attentiondeficit/hyperactivity disorder, conduct disorder, and sex on adolescent substance use and abuse. Arch Gen Psychiatry 2007;64: 1145-1152.

135) O'Brien LM, Gozal D. Sleep in children with attention deficit/hyperactivity disorder. Minerva Pediatr 2004;56:585-601.

136) Konrad A, Dielentheis TF, El Masri D, Bayerl M, Fehr C, Gesierich T, et al. Disturbed structural connectivity is related to inattention and impulsivity in adult attention deficit hyperactivity disorder. Eur J Neurosci 2010;31:912-919.

137) Ashtari M, Kumra S, Bhaskar SL, Clarke T, Thaden E, Cervellione $\mathrm{KL}$, et al. Attention-deficit/hyperactivity disorder: a preliminary diffusion tensor imaging study. Biol Psychiatry 2005;57:448-455.

138) Klein RG, Mannuzza S, Olazagasti MA, Roizen E, Hutchison JA, Lashua EC, et al. Clinical and functional outcome of childhood attention-deficit/hyperactivity disorder 33 years later. Arch Gen Psychiatry 2012;69:1295-1303.

139) Cortese S, Angriman M, Maffeis C, Isnard P, Konofal E, Lecendreux M, et al. Attention-deficit/hyperactivity disorder (ADHD) and obesity: a systematic review of the literature. Crit Rev Food Sci Nutr 2008;48:524-537.

140) Wilens TE, Spencer TJ, Biederman J. A review of the pharmacotherapy of adults with attention-deficit/hyperactivity disorder. J Atten Disord 2002;5:189-202.

141) Larson K, Russ SA, Kahn RS, Halfon N. Patterns of comorbidity, functioning, and service use for US children with ADHD, 2007. Pediatrics 2011;127:462-470.

142) McCann BS, Roy-Byrne P. Screening and diagnostic utility of selfreport attention deficit hyperactivity disorder scales in adults. Compr Psychiatry 2004;45:175-183.

143) Adler L, Cohen J. Diagnosis and evaluation of adults with attention-deficit/hyperactivity disorder. Psychiatr Clin North Am 2004; 27:187-201.

144) Moffitt TE, Houts R, Asherson P, Belsky DW, Corcoran DL, Hammerle $\mathbf{M}$, et al. Is adult ADHD a childhood-onset neurodevelopmental disorder? evidence from a four-decade longitudinal cohort study. Am J Psychiatry 2015;172:967-977.

145) Murphy K, Barkley RA. Attention deficit hyperactivity disorder adults: comorbidities and adaptive impairments. Compr Psychiatry 1996;37:393-401.

146) Posner K, Melvin GA, Murray DW, Gugga SS, Fisher P, Skrobala A, et al. Clinical presentation of attention-deficit/hyperactivity disorder in preschool children: the Preschoolers with AttentionDeficit/Hyperactivity Disorder Treatment Study (PATS). J Child Adolesc Psychopharmacol 2007;17:547-562.

147) Vitiello B, Lazzaretto D, Yershova K, Abikoff H, Paykina N, McCracken JT, et al. Pharmacotherapy of the Preschool ADHD Treatment Study (PATS) Children Growing Up. J Am Acad Child Adolesc Psychiatry 2015;54:550-556.

148) Souza I, Pinheiro MA, Mattos P. [Anxiety disorders in an attention-deficit/hyperactivity disorder clinical sample]. Arq Neuropsiquiatr 2005;63:407-409.

149) Loe IM, Feldman HM. Academic and educational outcomes of children with ADHD. J Pediatr Psychol 2007;32:643-654.

150) Bizzarri JV, Rucci P, Sbrana A, Gonnelli C, Massei GJ, Ravani L, et al. Reasons for substance use and vulnerability factors in patients with substance use disorder and anxiety or mood disorders. Addict Behav 2007;32:384-391.

151) Yoshimasu K, Barbaresi WJ, Colligan RC, Voigt RG, Killian JM, Weaver AL, et al. Childhood ADHD is strongly associated with a broad range of psychiatric disorders during adolescence: a population-based birth cohort study. J Child Psychol Psychiatry 2012;53: 1036-1043.

152) Sachs GS, Baldassano CF, Truman CJ, Guille C. Comorbidity of 
attention deficit hyperactivity disorder with early- and late-onset bipolar disorder. Am J Psychiatry 2000;157:466-468.

153) Ko CH, Yen JY, Yen CF, Chen CS, Chen CC. The association between Internet addiction and psychiatric disorder: a review of the literature. Eur Psychiatry 2012;27:1-8.

154) Ha JH, Yoo HJ, Cho IH, Chin B, Shin D, Kim JH. Psychiatric comorbidity assessed in Korean children and adolescents who screen positive for Internet addiction. J Clin Psychiatry 2006;67:821826.

155) Kent KM, Pelham WE Jr, Molina BS, Sibley MH, Waschbusch DA, Yu J, et al. The academic experience of male high school students with ADHD. J Abnorm Child Psychol 2011;39:451-462.

156) Biederman J, Mick E, Faraone SV. Age-dependent decline of symptoms of attention deficit hyperactivity disorder: impact of remission definition and symptom type. Am J Psychiatry 2000;157: 816-818.

157) Nigg JT, Stavro G, Ettenhofer M, Hambrick DZ, Miller T, Henderson JM. Executive functions and ADHD in adults: evidence for selective effects on ADHD symptom domains. J Abnorm Psychol 2005;114:706-717.

158) Biederman J. Attention-deficit/hyperactivity disorder: a selective overview. Biol Psychiatry. 2005;57:1215-1220.

159) Döpfner M, Breuer D, Wille N, Erhart M, Ravens-Sieberer U; BELLA study group. How often do children meet ICD-10/DSMIV criteria of attention deficit-/hyperactivity disorder and hyperkinetic disorder? Parent-based prevalence rates in a national sample--results of the BELLA study. Eur Child Adolesc Psychiatry 2008;17 Suppl 1:59-70.

160) Kim HY, Lee JY, Cho SS, Lee IS, Kim JH. A preliminary study on reliability and validity of the conners adult ADHD Rating ScalesKorean version in college students. Korean J Clin Psychol 2005;24: 171-185.

161) Connor DF, Steeber J, McBurnett K. A review of attention-deficit/ hyperactivity disorder complicated by symptoms of oppositional defiant disorder or conduct disorder. J Dev Behav Pediatr 2010;31: 427-440.

162) Millstein RB, Wilens TE, Biederman J, Spencer TJ. Presenting ADHD symptoms and subtypes in clinically referred adults with ADHD. J Atten Disord 1997;2:159-166.

163) Derogatis LR. SCL-90. Administration, scoring and procedures manual-I for the R (revised) version and other instruments of the Psychopathology Rating Scales Series. Chicago: Johns Hopkins University School of Medicine, 1977.

164) Jain M, Palacio LG, Castellanos FX, Palacio JD, Pineda D, Restrepo MI, et al. Attention-deficit/hyperactivity disorder and comorbid disruptive behavior disorders: evidence of pleiotropy and new susceptibility loci. Biol Psychiatry 2007;61:1329-1339.

165) Christiansen H, Chen W, Oades RD, Asherson P, Taylor EA, Lasky-Su J, et al. Co-transmission of conduct problems with attention-deficit/hyperactivity disorder: familial evidence for a distinct disorder. J Neural Transm (Vienna) 2008;115:163-175.

166) Lee WI, Kim JJ. A Preliminary Study on the Relationship between Drug Reactions Effects, Personality Type and ADHD Subtypes in Adult ADHD. Chung-Ang J Med 2012;37:59-64.

167) Loeber R, Green SM, Lahey BB, Frick PJ, McBurnett K. Findings on disruptive behavior disorders from the first decade of the Developmental Trends Study. Clin Child Fam Psychol Rev 2000;3: 37-60.

168) Biederman J, Wilens T, Mick E, Milberger S, Spencer TJ, Faraone SV. Psychoactive substance use disorders in adults with attention deficit hyperactivity disorder (ADHD): effects of ADHD and psychiatric comorbidity. Am J Psychiatry 1995;152:1652-1658.

169) Ostrander R, Crystal DS, August G. Attention deficit-hyperactivity disorder, depression, and self- and other-assessments of social competence: a developmental study. J Abnorm Child Psychol
2006:34:773-787.

170) Gadow KD, Nolan EE, Sverd J, Sprafkin J, Schwartz J. Anxiety and depression symptoms and response to methylphenidate in children with attention-deficit hyperactivity disorder and tic disorder. J Clin Psychopharmacol 2002;22:267-274.

171) Kunwar A, Dewan M, Faraone SV. Treating common psychiatric disorders associated with attention-deficit/hyperactivity disorder. Expert Opin Pharmacother 2007;8:555-562.

172) Reimherr FW, Marchant BK, Strong RE, Hedges DW, Adler L, Spencer TJ, et al. Emotional dysregulation in adult ADHD and response to atomoxetine. Biol Psychiatry 2005;58:125-131.

173) Lee SS, Humphreys KL, Flory K, Liu R, Glass K. Prospective association of childhood attention-deficit/hyperactivity disorder (ADHD) and substance use and abuse/dependence: a meta-analytic review. Clin Psychol Rev 2011;31:328-341.

174) Donfrancesco R, Miano S, Martines F, Ferrante L, Melegari MG, Masi G. Bipolar disorder co-morbidity in children with attention deficit hyperactivity disorder. Psychiatry Res 2011;186:333-337.

175) Nierenberg AA, Miyahara S, Spencer T, Wisniewski SR, Otto MW, Simon N, et al. Clinical and diagnostic implications of lifetime attention-deficit/hyperactivity disorder comorbidity in adults with bipolar disorder: data from the first 1000 STEP-BD participants. Biol Psychiatry 2005;57:1467-1473.

176) Walshaw PD, Alloy LB, Sabb FW. Executive function in pediatric bipolar disorder and attention-deficit hyperactivity disorder: in search of distinct phenotypic profiles. Neuropsychol Rev 2010;20: 103-120.

177) Murphy KR, Adler LA. Assessing attention-deficit/hyperactivity disorder in adults: focus on rating scales. J Clin Psychiatry 2004;65 Suppl 3:12-17.

178) Rösler M, Retz W, Thome J, Schneider M, Stieglitz RD, Falkai P. Psychopathological rating scales for diagnostic use in adults with attention-deficit/hyperactivity disorder (ADHD). Eur Arch Psychiatry Clin Neurosci 2006;256 Suppl 1:i3-i11.

179) Biederman J, Ball SW, Monuteaux MC, Mick E, Spencer TJ, McCreary M, et al. J Am Acad Child Adolesc Psychiatry 2008;47:426434.

180) Freitag CM, Rohde LA, Lempp T, Romanos M. Phenotypic and measurement influences on heritability estimates in childhood ADHD. Eur Child Adolesc Psychiatry 2010;19:311-323.

181) Bowen R, Chavira DA, Bailey K, Stein MT, Stein MB. Nature of anxiety comorbid with attention deficit hyperactivity disorder in children from a pediatric primary care setting. Psychiatry Res 2008:157:201-209.

182) Barkley RA, Fischer M, Smallish L, Fletcher K. Young adult follow-up of hyperactive children: antisocial activities and drug use. J Child Psychol Psychiatry 2004;45:195-211.

183) Serra-Pinheiro MA, Coutinho ES, Souza IS, Pinna C, Fortes D, Araújo C, et al. Is ADHD a risk factor independent of conduct disorder for illicit substance use? A meta-analysis and metaregression investigation. J Atten Disord 2013;17:459-469.

184) Spencer T, Biederman M, Coffey B, Geller D, Wilens T, Faraone S. The 4-year course of tic disorders in boys with attention-deficit/hyperactivity disorder. Arch Gen Psychiatry 1999;56:842-847.

185) Spencer TJ, Biederman J, Faraone S, Mick E, Coffey B, Geller D, et al. Impact of tic disorders on ADHD outcome across the life cycle: findings from a large group of adults with and without ADHD. Am J Psychiatry 2001;158:611-617.

186) Himle MB, Woods DW. An experimental evaluation of tic suppression and the tic rebound effect. Behav Res Ther 2005;43:14431451.

187) Kollins SH. ADHD, substance use disorders, and psychostimulant treatment: current literature and treatment guidelines. J Atten Disord 2008; 12:115-125.

188) Biederman J, Monuteaux MC, Spencer T, Wilens TE, Macpherson 
HA, Faraone SV. Stimulant therapy and risk for subsequent substance use disorders in male adults with ADHD: a naturalistic controlled 10-year follow-up study. Am J Psychiatry 2008;165:597-603.

189) Molina BS, Pelham WE Jr. Childhood predictors of adolescent substance use in a longitudinal study of children with ADHD. J Abnorm Psychol 2003;112:497-507.

190) Wilens TE, Martelon M, Joshi G, Bateman C, Fried R, Petty C, et al. Does ADHD predict substance-use disorders? A 10-year follow-up study of young adults with ADHD. J Am Acad Child Adolesc Psychiatry 2011;50:543-553.

191) Kuczenski R, Segal DS. Stimulant actions in rodents: implications for attention-deficit/hyperactivity disorder treatment and potential substance abuse. Biol Psychiatry 2005;57:1391-1396.

192) Groman SM, James AS, Jentsch JD. Poor response inhibition: at the nexus between substance abuse and attention deficit/hyperactivity disorder. Neurosci Biobehav Rev 2009;33:690-698.

193) Frodl T. Comorbidity of ADHD and substance use disorder (SUD): a neuroimaging perspective. J Atten Disord 2010;14:109-120.

194) Yoo HJ, Cho SC, Ha J, Yune SK, Kim SJ, Hwang J, et al. Attention deficit hyperactivity symptoms and internet addiction. Psychiatry Clin Neurosci 2004;58:487-494.

195) Ko CH, Yen JY, Chen CS, Chen CC, Yen CF. Psychiatric comorbidity of internet addiction in college students: an interview study. CNS Spectr 2008;13:147-153.

196) Miller CJ, Flory JD, Miller SR, Harty SC, Newcorn JH, Halperin JM. Childhood attention-deficit/hyperactivity disorder and the emergence of personality disorders in adolescence: a prospective follow-up study. J Clin Psychiatry 2008;69:1477-1484.

197) Fossati A, Novella L, Donati D, Donini M, Maffei C. History of childhood attention deficit/hyperactivity disorder symptoms and borderline personality disorder: a controlled study. Compr Psychiatry 2002;43:369-377.

198) Lampe K, Konrad K, Kroener S, Fast K, Kunert HJ, Herpertz SC. Neuropsychological and behavioural disinhibition in adult ADHD compared to borderline personality disorder. Psychol Med 2007; 37:1717-1729.

199) Levy LD, Fleming JP, Klar D. Treatment of refractory obesity in severely obese adults following management of newly diagnosed attention deficit hyperactivity disorder. Int J Obes (Lond) 2009;33: 326-334.

200) Molina BS, Hinshaw SP, Swanson JM, Arnold LE, Vitiello B, Jensen PS, et al. The MTA at 8 years: prospective follow-up of children treated for combined-type ADHD in a multisite study. J Am Acad Child Adolesc Psychiatry 2009;48:484-500.

201) Pliszka SR, Crismon ML, Hughes CW, Corners CK, Emslie GJ, Jensen PS, et al. The Texas Children's Medication Algorithm Project: revision of the algorithm for pharmacotherapy of attentiondeficit/hyperactivity disorder. J Am Acad Child Adolesc Psychiatry 2006;45:642-657.

202) Zuvekas SH, Vitiello B. Stimulant medication use in children: a 12-year perspective. Am J Psychiatry 2012;169:160-166.

203) Southammakosane C, Schmitz K. Pediatric psychopharmacology for treatment of ADHD, depression, and anxiety. Pediatrics 2015; 136:351-359.

204) Subcommittee on Attention-Deficit/Hyperactivity Disorder; Steering Committee on Quality Improvement and Management, Wolraich M, Brown L, Brown RT, DuPaul G, et al. ADHD: clinical practice guideline for the diagnosis, evaluation, and treatment of attention-deficit/hyperactivity disorder in children and adolescents. Pediatrics 2011;128:1007-1022.

205) Yoo HJ, Yang SJ, Shin D, Kang H, Kim BN, Kim JH, et al. The Korean Practice Parameter for the Treatment of Attention-Deficit Hyperactivity Disorder (III) : Pharmacologic Treatment. J Korean Acad Child Adolesc Psychiatry 2007;18:16-25.

206) Biederman J, Mick E, Surman C, Doyle R, Hammerness P, Har- pold $\mathrm{T}$, et al. A randomized, placebo-controlled trial of OROS methylphenidate in adults with attention-deficit/hyperactivity disorder. Biol Psychiatry 2006;59:829-835.

207) Jensen PS, Hinshaw SP, Kraemer HC, Lenora N, Newcorn JH, Abikoff HB, et al. ADHD comorbidity findings from the MTA study: comparing comorbid subgroups. J Am Acad Child Adolesc Psychiatry 2001;40:147-158.

208) Pelham WE Jr, Sturges J, Hoza J, Schmidt C, Bijlsma JJ, Milich R, et al. Sustained release and standard methylphenidate effects on cognitive and social behavior in children with attention deficit disorder. Pediatrics 1987;80:491-501.

209) Armstrong RB, Damaraju CV, Ascher S, Schwarzman L, O'Neill J, Starr HL. Time course of treatment effect of OROS ${ }^{\circledR}$ methylphenidate in children with ADHD. J Atten Disord 2012;16:697705 .

210) Wigal SB, Gupta S, Heverin E, Starr HL. Pharmacokinetics and therapeutic effect of OROS methylphenidate under different breakfast conditions in children with attention-deficit/hyperactivity disorder. J Child Adolesc Psychopharmacol 2011;21:255-263.

211) Childress A, Sallee FR. The use of methylphenidate hydrochloride extended-release oral suspension for the treatment of ADHD. Expert Rev Neurother 2013;13:979-988.

212) Swanson J, Gupta S, Lam A, Shoulson I, Lerner M, Modi N, et al. Development of a new once-a-day formulation of methylphenidate for the treatment of attention-deficit/hyperactivity disorder: proofof-concept and proof-of-product studies. Arch Gen Psychiatry 2003;60:204-211.

213) Steele M, Weiss M, Swanson J, Wang J, Prinzo RS, Binder CE. A randomized, controlled effectiveness trial of OROS-methylphenidate compared to usual care with immediate-release methylphenidate in attention deficit-hyperactivity disorder. Can J Clin Pharmacol 2006;13:e50-e62.

214) Anderson VR, Keating GM. Methylphenidate controlled-delivery capsules (EquasymXL, Metadate CD): a review of its use in the treatment of children and adolescents with attention-deficit hyperactivity disorder. Paediatr Drugs 2006;8:319-333.

215) Brams M, Mao AR, Doyle RL. Onset of efficacy of long-acting psychostimulants in pediatric attention-deficit/hyperactivity disorder. Postgrad Med 2008;120:69-88.

216) Biederman J, Quinn D, Weiss M, Markabi S, Weidenman M, Edson K, et al. Efficacy and safety of Ritalin LA, a new, once daily, extended-release dosage form of methylphenidate, in children with attention deficit hyperactivity disorder. Paediatr Drugs 2003; 5:833-841.

217) Swanson J, Greenhill L, Wigal T, Kollins S, Stehli A, Davies M, et al. Stimulant-related reductions of growth rates in the PATS. J Am Acad Child Adolesc Psychiatry 2006;45:1304-1313.

218) Greenhill L, Kollins S, Abikoff H, McCracken J, Riddle M, Swanson J, et al. Efficacy and safety of immediate-release methylphenidate treatment for preschoolers with ADHD. J Am Acad Child Adolesc Psychiatry 2006;45:1284-1293.

219) Greenhill LL, Pliszka S, Dulcan MK, Bernet W, Arnold V, Beitchman J, et al. Practice parameter for the use of stimulant medications in the treatment of children, adolescents, and adults. J Am Acad Child Adolesc Psychiatry 2002;41(2 Suppl):26S-49S

220) Wilens TE, Adler LA, Adams J, Sgambati S, Rotrosen J, Sawtelle R, et al. Misuse and diversion of stimulants prescribed for ADHD: a systematic review of the literature. J Am Acad Child Adolesc Psychiatry 2008;47:21-31.

221) Kratochvil CJ, Vaughan BS, Harrington MJ, Burke WJ. Atomoxetine: a selective noradrenaline reuptake inhibitor for the treatment of attention-deficit/hyperactivity disorder. Expert Opin Pharmacother 2003;4:1165-1174.

222) Michelson D, Allen AJ, Busner J, Casat C, Dunn D, Kratochvil C, et al. Once-daily atomoxetine treatment for children and adoles- 
cents with attention deficit hyperactivity disorder: a randomized, placebo-controlled study. Am J Psychiatry 2002;159:1896-1901.

223) Kratochvil CJ, Milton DR, Vaughan BS, Greenhill LL. Acute atomoxetine treatment of younger and older children with ADHD: a meta-analysis of tolerability and efficacy. Child Adolesc Psychiatry Ment Health 2008;2:25.

224) Tauscher-Wisniewski S, Nilsson M, Caldwell C, Plewes J, Allen AJ. Meta-analysis of aggression and/or hostility-related events in children and adolescents treated with fluoxetine compared with placebo. J Child Adolesc Psychopharmacol 2007;17:713-718.

225) Signorovitch J, Erder MH, Xie J, Sikirica V, Lu M, Hodgkins PS, et al. Comparative effectiveness research using matching-adjusted indirect comparison: an application to treatment with guanfacine extended release or atomoxetine in children with attentiondeficit/hyperactivity disorder and comorbid oppositional defiant disorder. Pharmacoepidemiol Drug Saf 2012;21 Suppl 2:130-137.

226) Sumner C, Sher L, Sutton V, Bakken R, Paczkowski M, Trzepacz P, et al. Atomoxetine treatment for pediatric patients with ADHD and comorbid anxiety. Neuropediatrics 2006;37:TP74.

227) Schwartz S, Correll CU. Efficacy and safety of atomoxetine in children and adolescents with attention-deficit/hyperactivity disorder: results from a comprehensive meta-analysis and metaregression. J Am Acad Child Adolesc Psychiatry 2014;53:174-187.

228) Waxmonsky JG, Waschbusch DA, Akinnusi O, Pelham WE. A comparison of atomoxetine administered as once versus twice daily dosing on the school and home functioning of children with attention-deficit/hyperactivity disorder. J Child Adolesc Psychopharmacol 2011;21:21-32.

229) Wernicke JF, Kratochvil CJ. Safety profile of atomoxetine in the treatment of children and adolescents with ADHD. J Clin Psychiatry 2002;63 Suppl 12:50-55.

230) van Zwieten PA, Chalmers JP. Different types of centrally acting antihypertensives and their targets in the central nervous system. Cardiovasc Drugs Ther 1994;8:787-799.

231) Hunt RD, Arnsten AF, Asbell MD. An open trial of guanfacine in the treatment of attention-deficit hyperactivity disorder. J Am Acad Child Adolesc Psychiatry 1995;34:50-54.

232) Posey DJ, McDougle CJ. Guanfacine and guanfacine extended release: treatment for ADHD and related disorders. CNS Drug Rev 2007;13:465-474

233) Hunt RD, Capper L, O'Connell P. Clonidine in child and adolescent psychiatry. J Child Adolesc Psychopharmacol 1990;1:87-102.

234) Hirota T, Schwartz S, Correll CU. Alpha-2 agonists for attentiondeficit/hyperactivity disorder in youth: a systematic review and meta-analysis of monotherapy and add-on trials to stimulant therapy. J Am Acad Child Adolesc Psychiatry 2014;53:153-173.

235) Kollins SH, Jain R, Brams M, Segal S, Findling RL, Wigal SB, et al. Clonidine extended-release tablets as add-on therapy to psychostimulants in children and adolescents with ADHD. Pediatrics 2011;127:e1406-e1413.

236) Jain R, Segal S, Kollins SH, Khayrallah M. Clonidine extended-release tablets for pediatric patients with attention-deficit/hyperactivity disorder. J Am Acad Child Adolesc Psychiatry 2011;50:171179.

237) Croxtall JD. Clonidine extended-release in attention-deficit hyperactivity disorder: profile report. CNS Drugs 2012;26:277-279.

238) Sallee F, Connor DF, Newcorn JH. A review of the rationale and clinical utilization of $\alpha 2$-adrenoceptor agonists for the treatment of attention-deficit/hyperactivity and related disorders. J Child Adolesc Psychopharmacol 2013;23:308-319.

239) Wang M, Ramos BP, Paspalas CD, Shu Y, Simen A, Duque A, et al. Alpha2A-adrenoceptors strengthen working memory networks by inhibiting cAMP-HCN channel signaling in prefrontal cortex. Cell 2007;129:397-410.

240) Newcorn JH, Schulz K, Harrison M, DeBellis MD, Udarbe JK,
Halperin JM. Alpha 2 adrenergic agonists. Neurochemistry, efficacy, and clinical guidelines for use in children. Pediatr Clin North Am 1998;45:1099-1022, viii.

241) Ruggiero S, Clavenna A, Reale L, Capuano A, Rossi F, Bonati M. Guanfacine for attention deficit and hyperactivity disorder in pediatrics: a systematic review and meta-analysis. Eur Neuropsychopharmacol 2014;24:1578-1590.

242) Shier AC, Reichenbacher T, Ghuman HS, Ghuman JK. Pharmacological treatment of attention deficit hyperactivity disorder in children and adolescents: clinical strategies. J Cent Nerv Syst Dis 2013;5:1-17.

243) Daviss WB, Perel JM, Rudolph GR, Axelson DA, Gilchrist R, Nuss S, et al. Steady-state pharmacokinetics of bupropion SR in juvenile patients. J Am Acad Child Adolesc Psychiatry 2005;44: 349-357.

244) Daviss WB, Perel JM, Birmaher B, Rudolph GR, Melhem I, Axelson DA, et al. Steady-state clinical pharmacokinetics of bupropion extended-release in youths. J Am Acad Child Adolesc Psychiatry 2006;45:1503-1509.

245) Dhillon S, Yang LP, Curran MP. Bupropion: a review of its use in the management of major depressive disorder. Drugs 2008;68:653689.

246) Mészáros A, Czobor P, Bálint S, Komlósi S, Simon V, Bitter I. Pharmacotherapy of adult attention deficit hyperactivity disorder (ADHD): a meta-analysis. Int J Neuropsychopharmacol 2009;12: 1137-1147.

247) Elia J, Ambrosini PJ, Rapoport JL. Treatment of attention-deficithyperactivity disorder. N Engl J Med 1999;340:780-788.

248) Waxmonsky JG. Nonstimulant therapies for attention-deficit hyperactivity disorder (ADHD) in children and adults. Essent Psychopharmacol 2005;6:262-276.

249) Taketomo CK, Hodding JH, Kraus DM. Lexi-Comp's Pediatric Dosage Handbook: Including Neonatal Dosing, Drug Administration, \& Extemporaneous Preparations. Hudson, OH: Lexi-Comp; 2004.

250) Stein BD, Klein GR, Greenhouse JB, Kogan JN. Treatment of attention-deficit hyperactivity disorder: patterns of evolving care during the first treatment episode. Psychiatr Serv 2012;63:122129.

251) Emilsson B, Gudjonsson G, Sigurdsson JF, Baldursson G, Einarsson E, Olafsdottir $\mathrm{H}$, et al. Cognitive behaviour therapy in medication-treated adults with ADHD and persistent symptoms: a randomized controlled trial. BMC Psychiatry 2011;11:116.

252) Safren SA, Sprich S, Mimiaga MJ, Surman C, Knouse L, Groves M, et al. Cognitive behavioral therapy vs relaxation with educational support for medication-treated adults with ADHD and persistent symptoms: a randomized controlled trial. JAMA 2010;304:875880.

253) National Collaborating Centre for Mental Health (UK). Attention deficit hyperactivity disorder: diagnosis and management of ADHD in children, young people and adults. Leicester: British Psychological Society (UK);2009.

254) Kooij SJ, Bejerot S, Blackwell A, Caci H, Casas-Brugué M, Carpentier PJ, et al. European consensus statement on diagnosis and treatment of adult ADHD: the European Network Adult ADHD. BMC Psychiatry 2010;10:67.

255) Gjervan B, Torgersen T, Nordahl HM, Rasmussen K. Functional impairment and occupational outcome in adults with ADHD. J Atten Disord 2012;16:544-552.

256) Patterson GR. Coercive family process. Eugene, OR: Castalia Pub. Co.;1982.

257) Hautmann C, Stein P, Hanisch C, Eichelberger I, Plück J, Walter D, et al. Does parent management training for children with externalizing problem behavior in routine care result in clinically significant changes? Psychother Res 2009;19:224-233. 
258) Sonuga-Barke EJ, Daley D, Thompson M, Laver-Bradbury C, Weeks A. Parent-based therapies for preschool attention-deficit/ hyperactivity disorder: a randomized, controlled trial with a community sample. J Am Acad Child Adolesc Psychiatry 2001;40:402408.

259) Barkley RA, Guevremont DC, Anastopoulos AD, Fletcher KE. A comparison of three family therapy programs for treating family conflicts in adolescents with attention-deficit hyperactivity disorder. J Consult Clin Psychol 1992;60:450-462.

260) Webster-Stratton C. The incredible years: a troubleshooting guide for parents of children aged 3-8. Toronto: Umbrella Press;1992.

261) Kazdin AE. Parent management training: evidence, outcomes, and issues. J Am Acad Child Adolesc Psychiatry 1997;36:1349-1356.

262) DuPaul GJ, Gormley MJ, Laracy SD. School-based interventions for elementary school students with ADHD. Child Adolesc Psychiatr Clin N Am 2014;23:687-697.

263) Gormley MJ, Dupaul GJ. Teacher-to-teacher consultation: facilitating consistent and effective intervention across grade levels for students with ADHD. Psychol Sch 2015;52:124-138.

264) Fabiano GA, Pelham Jr WE, Gnagy EM, Burrows-MacLean L, Coles EK, Chacko A, et al. The single and combined effects of multiple intensities of behavior modification and methylphenidate for children with attention deficit hyperactivity disorder in a classroom setting. Sch Psychol Rew 2007;36:195-216.

265) Evans SW, Owens JS, Bunford N. Evidence-based psychosocial treatments for children and adolescents with attention-deficit/hyperactivity disorder. J Clin Child Adolesc Psychol 2014;43:527-551.

266) Abikoff H, Gittelman R. Hyperactive children treated with stimulants. Is cognitive training a useful adjunct? Arch Gen Psychiatry 1985;42:953-961.

267) Dush DM, Hirt ML, Schroeder HE. Self-statement modification in the treatment of child behavior disorders: a meta-analysis. Psychol Bull 1989;106:97-106.

268) Bear RA, Nietzel MT. Cognitive and behavioral treatment of impulsivity in children: a meta-analytic review of the outcome literature. J Clin Child Psychol 1991;20:400-412.

269) Bloomquist ML, August GJ, Ostrander R. Effects of a schoolbased cognitive-behavioral intervention for ADHD children. J Abnorm Child Psychol 1991;19:591-605.

270) Antshel KM, Faraone SV, Gordon M. Cognitive behavioral treatment outcomes in adolescent ADHD. J Atten Disord 2014;18:483495.

271) van de Weijer-Bergsma E, Formsma AR, de Bruin EI, Bögels SM. The effectiveness of mindfulness training on behavioral problems and attentional functioning in adolescents with ADHD. J Child Fam Stud 2012;21:775-787.

272) Sibley MH, Pelham Jr WE, Derefinko KJ, Kuriyan AB, Sanchez F, Graziano PA. A pilot trial of supporting teens' academic needs daily (STAND): a parent-adolescent collaborative intervention for ADHD. J Psychopathol Behav Assess 2013;35:436-449.

273) Fohlmann AH. Social skills training [Social færdighedstræning [Danish]]. In: Kjær SK, Nordentoft M, Melau M, Iversen T, editors. Psykose hos unge. Copenhagen: Psykiatrifondens forlag; 2009.

274) Jolles DD, Crone EA. Training the developing brain: a neurocognitive perspective. Front Hum Neurosci 2012;6:76.

275) Willis SL, Schaie KW. Cognitive training and plasticity: theoretical perspective and methodological consequences. Restor Neurol Neurosci 2009;27:375-389.
276) Karch D, Albers L, Renner G, Lichtenauer N, von Kries R. The efficacy of cognitive training programs in children and adolescents: a meta-analysis. Dtsch Arztebl Int 2013;110:643-652.

277) Beauregard M, Lévesque J. Functional magnetic resonance imaging investigation of the effects of neurofeedback training on the neural bases of selective attention and response inhibition in children with attention-deficit/hyperactivity disorder. Appl Psychophysiol Biofeedback 2006;31:3-20.

278) Kim HL, Kim JW, Hong SB, Cho JH, Kim BN, Shin MS, et al. Effects of neurofeedback in children with attention deficit hyperactivity disorder: a preliminary study. J Korean Neuropsychiatr Assoc 2012;51:326-334.

279) Knouse LE, Safren SA. Current status of cognitive behavioral therapy for adult attention-deficit hyperactivity disorder. Psychiatr Clin North Am 2010;33:497-509.

280) Gevensleben H, Holl B, Albrecht B, Vogel C, Schlamp D, Kratz O, et al. Is neurofeedback an efficacious treatment for ADHD? A randomised controlled clinical trial. J Child Psychol Psychiatry 2009;50:780-789.

281) Kwon MS. Effects of neuro-feedback training including behaviour contract with ADHD. Seoul: Kyung Hee Univ.;2012.

282) Roh OB, Son CN, Park TW, Park SK. The effects of neurofeedback training on inattention and hyperactivity/impulsivity in children with ADHD. Korean J Clin Psychol 2011;30:397-418.

283) Lansbergen MM, van Dongen-Boomsma M, Buitelaar JK, SlaatsWillemse D. ADHD and EEG-neurofeedback: a double-blind randomized placebo-controlled feasibility study. J Neural Transm (Vienna) 2011;118:275-284

284) Kessler RC, Adler L, Ames M, Barkley RA, Birnbaum H, Greenberg $\mathrm{P}$, et al. The prevalence and effects of adult attention deficit/ hyperactivity disorder on work performance in a nationally representative sample of workers. J Occup Environ Med 2005;47:565572

285) Safren SA. Cognitive-behavioral approaches to ADHD treatment in adulthood. J Clin Psychiatry 2006;67 Suppl 8:46-50.

286) Young S, Amarasinghe JM. Practitioner review: non-pharmacological treatments for ADHD: a lifespan approach. J Child Psychol Psychiatry 2010;51:116-133.

287) Ramsay JR. Current status of cognitive-behavioral therapy as a psychosocial treatment for adult attention-deficit/hyperactivity disorder. Curr Psychiatry Rep 2007;9:427-433.

288) Drechsler R, Straub M, Doehnert M, Heinrich H, Steinhausen HC, Brandeis D. Controlled evaluation of a neurofeedback training of slow cortical potentials in children with attention deficit/hyperactivity disorder (ADHD). Behav Brain Funct 2007;3:35.

289) Safren SA, Otto MW, Sprich S, Winett CL, Wilens TE, Biederman J. Cognitive-behavioral therapy for ADHD in medication-treated adults with continued symptoms. Behav Res Ther 2005;43:831-842.

290) Solanto MV, Marks DJ, Wasserstein J, Mitchell K, Abikoff H, Alvir JM, et al. Efficacy of meta-cognitive therapy for adult ADHD. Am J Psychiatry 2010;167:958-968.

291) Ramos-Quiroga JA, Montoya A, Kutzelnigg A, Deberdt W, Sobanski E. Attention deficit hyperactivity disorder in the European adult population: prevalence, disease awareness, and treatment guidelines. Curr Med Res Opin 2013;29:1093-1104.

292) Feldman HM, Reiff MI. Clinical practice. Attention deficit-hyperactivity disorder in children and adolescents. N Engl J Med 2014; 370:838-846. 